\title{
Research Utilization in the Building Industry: Decision Model and Preliminary Assessment
}

October 1985

Prepared for the U.S. Department of Energy under Contract DE-AC06-76RLO 1830

Pacific Northwest Laboratory Operated for the U.S. Department of Energy by Battelle Memorial Institute 


\title{
DISCLAIMER
}

This report was prepared as an account of work sponsored by an agency of the United States Government. Neither the United States Government nor any agency thereof, nor any of their employees, makes any warranty, express or implied, or assumes any legal liability or responsibility for the accuracy, completeness, or usefulness of any information, apparatus, product, or process disclosed, or represents that its use would not infringe privately owned rights. Reference herein to any specific commercial product, process, or service by trade name, trademark, manufacturer, or otherwise, does not necessarily constitute or imply its endorsement, recommendation, or favoring by the United States Government or any agency thereof. The views and opinions of authors expressed herein do not necessarily state or reflect those of the United States Government or any agency thereof.

\author{
PACIFIC NORTHWEST LABORATORY \\ operated by \\ BATTELLE \\ for the \\ UNITED STATES DEPARTMENT OF ENERGY \\ under Contract DE-AC06-76RLO 1830
}

\begin{tabular}{|c|c|}
\hline \multirow{2}{*}{\multicolumn{2}{|c|}{ Printed in the United States of America }} \\
\hline & \\
\hline \multicolumn{2}{|c|}{ Available from } \\
\hline \multicolumn{2}{|c|}{$\begin{array}{l}\text { National Technical information Service } \\
\text { United States Department of Commerce }\end{array}$} \\
\hline \multirow{2}{*}{\multicolumn{2}{|c|}{$\begin{array}{l}5285 \text { Port Royal Road } \\
\text { Springfield, Virginia } 22161\end{array}$}} \\
\hline & Springfield, Virginia 22161 \\
\hline \multirow{2}{*}{\multicolumn{2}{|c|}{$\begin{array}{l}\text { NTIS Price Codes } \\
\text { Microfiche } A 01\end{array}$}} \\
\hline & \\
\hline \multicolumn{2}{|c|}{ Printed Copy } \\
\hline Pages & $\begin{array}{l}\text { Price } \\
\text { Codes }\end{array}$ \\
\hline $001-025$ & A02 \\
\hline 026-050 & $\mathrm{A} 03$ \\
\hline $051-075$ & A04 \\
\hline $076-100$ & A05 \\
\hline $101-125$ & A06 \\
\hline $126-150$ & $\mathrm{~A} 07$ \\
\hline 151.175 & $A 0 B$ \\
\hline $176-200$ & $\wedge 09$ \\
\hline $201-225$ & A010 \\
\hline $226-250$ & A011 \\
\hline $251-275$ & A 012 \\
\hline $276-300$ & A013 \\
\hline
\end{tabular}


RESEARCH UTILIZATION IN THE BUILDING INOUSTRY: DECISION

MOOEL AND PRELIMINARY ASSESSMENT
R. L. Watts
D. R. Johnson
S. A. Smith
E. J. Westergard

October 1985

Prepared for the U.S. Department of Energy under Contract DE-AC06-76RLO 1830

Pacific Northwest Laboratory Richland, washington 99352 


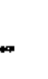




\section{ACKNOWLEDGMENTS}

The orogress made in the development of data and models in this report is more the result of the personal contributions of a large number of people than the review and synthesis of written literature. There appears to be little precedent for the models developed.

The direction and initial components of the Research Utilization Program were developed jointly by Oak Ridge National Laboratory (ORNL) and Pacific Northwest Laboratory (PNL) under the sponsorshio and guidance of Marvin Gorelick of the Building Systems Division (BSD) of the Office of Buitdings and Community Svstems (BCS), U.S. Dedartment of Energy (DOE). Thomas Vonier, Energy Committee Chairman for the American Institute of Architects, and Erv Bales, Research Professor of Architecture and Engineering at the New Jersey Institute of Technology, Schools of Architecture and Engineering, supported the steering of this oroject. This has been a collaborative effort in every sense. Tasks undertaken by both laboratories were designed to contribute svnergistically to an overall strategy for managing the interactions between the private and public sector in the area of building energy conservation. This team aporoach has allowed DOE to draw upon the strengths of both laboratories.

While it is impossible to list the names of everyone who contributed to this reoort, we will attempt to acknowledge some of those who made substantial contributions to the development of the decision process model:

John Franke, PNL Program Manager of the Research Utilization Program (RU), contributed many heloful concepts and made numerous constructive suggestions during the investiqation and predaration of the report.

Marvin Gorelick, DOE Program Manager of the Research Utilization Program, contributed many creative ideas for approaching the modeling of the RU process and encouragement at critical phases of the investigation.

Others who made substantial contributions include:

Tom Vonier of Vonier Associates, Chairman of the AIA Energy Committee Erv Bales of the New Jersey Institute of Technology (School of Architecture) 
Bill Seaton, Manager of Research at ASHRAE

E. J. Soderstrom, M. E. Brown, E. D. Copenhaver, J.H. Sorensen, Oak Ridge National Laboratory

The late Richard Campbell, the Tate Jim Easterling, Rich Mazzucchi, Stan Pansky, John Stoops, Pacific Northwest Laboratory

The following individuals contributed information used in developing

the decision process model:

Blair Abee, Owner Builder Center

Alan Adams, Windowvisions

Rene Adams, Torrant County Builder's Assn.

Tim Barber, Greg Linnerooth, Energy Control Product Division of

Minnesota Mining and Manufacturing

Joe Barrows, Bill Pelham, Wood Brothers Homes

Ben Bartolotto, Construction Industry Research Board

Duane Bauqer, Probuilt Systems

Jeff Bryson, Sunflake

Ray Champion, Dondi Construction

Enola Dangerfield, Builders Marketplace

Jim Delap lane, Todd Development Company

Ron Downs, Best Built, Inc.

Irvin Eaton, Sandy Snyder, Insoport Industries

Ross Fink, Johnson Controls, Inc.

Liz Fox, Suder Insulation Information Service

John Gold, Home \& Apt. Assn. Metro Dallas

Jim Greevers, Johnson Controls, Inc.

Bing Hacker, Hacker Homes

Cy Henry, Italix Lighting, Inc.

Bill Huston, Bob Rivinius, CA BIA

$0 . B$. Johnson, $0 . B$. Johnson, Inc.

Joe Kariakin, Novi Deve lopment Company

Robert Laris, Laris \& Assoc., Inc.

Thomas Lenchek, Balance Associates

Ryan Litchfield, Cascade Energy Homes

Bob Martin, Dividend Development Corooration

John Mephan, Tektronix-Control Service Group

$V$ ictor Mirontschuk, EDI Architects/Planners

Bob Moffett, E.I. DuPont de Nemours \& Company, Inc.

Ned Nisson, "Energy Design Update"

Lou is Novak, Pella Products

Vern 01 in, Dow-Ammons Builders

Jim Patton, Durango Owner Builder Center

Art Phillios, Boise Cascade

Howard M. Rider, Blower Door Testing

Lee Rudofsky, Almor Realty

Duane Searles, Colorado Association for Housing and Building

Linda Steinman, Washington State Energy Office

Bob Sterret, Litton Facilities Management System

Bill Streige?, J. E. Dunn Construction Co.

Mike Tagqart, Florida Home Builders Association 
James Alan Taylor, Daystar Group (Arch/Solar)

Jack Ul lrich, Andersen Corporation

Barbara Walker, Unique Homes of Colorado

Vincent Webers, DuPont Division of P\&EP

The following individuals contributed extensive time and effort to filling out pro forma model forms:

Robert W. Dowe11, General Growth Corporation

Lou is J. Lalli, LEHR Associates

Rick A. Martin, Urban Engineering

Stu Haberman

William w. Seaton, ASHRAE 



\section{EXECUTIVE SUMMARY AND RECOMMENDATIONS}

The Research Utilization Program was conceived as a far-reaching means for managing the interactions of the private sector and the federal research sector as they deal with energy conservation in buildings. The program emphasizes a private-public partnership in planning a research agenda and in applying the results of onqoing and completed research.

The results of this task support the hypothes is that the transfer of R\&D results to the buildings industry can be accomplished more efficiently and quickly by a systematic approach to technology transfer. This systematic aboroach involves targeting decision makers, assessing research and information needs, prover $1 \mathrm{v}$ formating information, and then transmitting the information through trusted channels.

\section{PURPOSE}

The purpose of this report is to introduce elements of a market-oriented knowledge base, which would be useful to the Building Systems Division, the Office of Buildings and Community Svstems and their associated laboratories in managing a private-public research bartnership on a rational systematic basis. This report presents conceptual models and data bases that can be used in formulating a technology transfer strategy and in planning technology transfer orograms.

\section{SCOPE}

This report presents the results of the Feedback and Evaluation Task of the Research Utilization Program. For this task, Pacific Northwest Laboratory examined the structure of the building industrv and its practices, particularly the diffusion of knowledqe and innovative technology. These topics are not covered exhaustively; however, sufficient information is presented to establish a knowledge base that supports a rationa? and systematic approach to technology transfer. Other elements of this knowledqe base are being addressed by the Oak Ridqe National Laboratory. 
In this task, a pro forma model of the decision process for planning, designing and constructing buildings was developed. The model was applied on a test basis to a limited portion of the building industry. Aiso, preliminary investigations have been conducted of the structure of the building industry, the mechanisms available for technology transfer, and the decision environment in which technology is adopted.

In the following sections, the investigations indertaken in the Feedback and Evaluation Task are summarized by chapter.

\section{CHAPTER 2: DECISION PROCESS MODEL}

A conceptual model was developed for mapping the interactions of energy conservation opportunities, decision participants and decision criteria. The model places these interactions in the context of the sequence of events occurring in the olanning, design, construction and occupancy of a building.

The decision process model provides a structure for locating energy conservation opportunities that occur throughout the phases in a building's iife. For particular energy conservation opoortunities, the model helps to identify key decision makers so that information $c$ an be targeted to the appropriate audience. In addition, the criteria used in making those decisions are identified so that information packages can be taijored to meet the needs of decision makers.

The model is a blanning tool for identifying target audiences for information transfer. Because no precedent exists in the literature, the model was created through extensive field investiqations. I*:5 structure and format were developed through numerous reviews and modifications by industry, university and laboratory personnel.

Preliminary inferences can be drawn from the results of these field investiqations:

- The process of selecting or rejecting an enerqy-savina technology involves muttiple decision makers. 
- Many decision participants have effective "veto power" over the adoption or use of a conservation technologv.

- The building owner appears to be the single areatest influence on energy efficiency investment.

- Patterns in the orocess of adopting an energy-saving technology can be identified by modeling the interactions of conservation opportunities, key decision participants and decision criteria.

- Adoption patterns differ for various combinations of building ownership, building use and contracting/construction mode.

- Financial, technical and aesthetic criteria appear to be more important than enerqy efficiency in building design.

\section{CHAPTER 3: A SEGMENTATION OF THE USERS OF BUILDING ENERGY}

CONSERVATION RESEARCH

The term "user" refers to firms and individuals who could potentially use the results of energy conservation research in plannina, designing, constructing and operating builitings. The user segmentation describes the actual composition of distinct groups of industry decision makers. The segmentation scheme is based on functional business areas (i.e., architecture, engineering, finance, etc.). Data and information are presented on the number of firms, their dollar business volume, their geographic distribution and other parameters for each industry segment.

The segmentation can be used either by itself as a source of market planning information or in conjunction with the decision process model. The major divisions of the segmentation (comprised of industry segments) correspond with the decision participant tyoes identified in the decision process model. Therefore, if the decision process model is used to identify decision participants for a given energy conservation opportunity, the industry segmentation can provide details on the correspondina groups of firms and individuals in the industry who actually make those decisions. 
The information on user segmentation is useful in several ways:

- Industry's fragmentation and size can be effectively dea it with by targeting information to we1l-defined industry segments.

- Industry segments to be targeted can be identified by applying the decision process mode 1 .

- Information tarqeting can be more effective when geographic and demographic factors are overlaid on functional industry segments.

\section{CHAPTER 4: TRANSFER MECHANSIMS AND THE DECISION ENVIRONMENT}

In the discussion of the decision environment, factors affecting the choice of mechanisms to be used in technology transfer are described. First, several transfer mechanisms are identified. These mechanisms fall broadly into three categories:

media mechanisms:

policy mechanisms:

R\&D process mechanisms: mechanisms that provide the means for communicating information through written, audio and/or visual images.

mechanisms that provide incentives for energy conservation through institutional arrangements. information through user involvement in planning, monitoring and evaluating research.

This chapter discusses conditions necessary for information to effectivelv change decision makers' behavior with regard to technology adoption. It highlights environmental factors that affect the transfer of technology to the private sector. Key Doints of that discussion include the following:

- Those who first use new technology appear to erphasize noncost-related criteria in their decision process.

- Multiple sources of information tend to re-enforce a new technology's credibilitv. 
- Impersonal transfer mechanisms (written or media) appear to be important in producing the awareness of a new technology.

- Actual adoption of new technology appears to require "people to people" information exchange.

- Credibility of information sources and media appears to be higher for technologies in which little new untested information is transmitted.

- Traditiona 1 information sources may be relatively less effective in transmitting information during the early stages of the introduction of new technology.

- Different transfer mechanisms become effective as decision makers progress through stages of increasing awareness and interest.

- Occupants or end users of buildings usually must demand energy conservation measures before decision makers will incorporate them.

- R\&D on the reliability of a concept is crucial for its adoption.

\section{RECOMMENDATIONS}

The following recommendations result from PNL's examination of the building industry and its practices.

1. The usefulness and validity of the decision process model needs to be assessed beyond the pretiminary application described in this report. This assessment could be conducted in a workshop setting with industry practitioners and other experts providing input data required to model additional building types. A workshop would give industry the opportunity to review the model and PNL would be able to observe generalized decision patterns that could help to simplify the model.

2. Effective information targeting will require further development of the user seqmentation:

- A computerized data base of industry firms should be created. The data base should have sort capability on parameters of interest, such as building type specialty, dollar business volume and geographic location. 
The data base would be based on the user segmentation and should be constructed to interact with the decison process model and the data base of building industry broker organizations created by ORNL. With this interaction, groups of firms could be targetad individually, directly or through broker organizations. Market penetration could also be tracked, which would allow someone to identify areas where further efforts should be concentrated.

- Concurrentlv, further research needs to be conducted on each industry segment in three areas: industry leadership, propensity to innovate and business oractices relative to the state of the art of building technology. This research would enhance the value and sort capability of the computerized data base, resulting in a powerful tool for identifying target audiences.

Industry Leadershio - Research on building industry leadership would focus on identifying those firms whose practices and specifications are emulated by others in the industry. This research could lead to the most efficient and effective way to demonstrate einerging technologies by working through industry leaders.

Propensity to Innovate - This research would focus on identifying demographic and other factors indicative of innovative behavior in firms. Knowing these characteristics would help in identifying industry leaders who are most likely to be receptive to adopting innovative technologies. State of the Art - This research would characterize each industry segment in terms of firms' practices concerning the state of the art in building technology. This characterization would be presented as a distribution of firms, with firms leading the state of the art on one end and those lagging on the other end. Knowing this distribution in rough quantitative terms would help define the content and format of information that could have the areatest impact in a given industry segment.

4. Transfer mechanisms that affect the R\&D process itself--user involvement in research, R\&D limited partnerships, industry quidance and review panels, 
etc.--should be more fullv developed in a topical report. Specific opportunities for their use in the Building Systems Division and the Office of Buildings and Community Systems should be identified.

5. This report provides the first installations of a knowledge base that will improve technology transfer. Further research into technology transfer methods is not soecifically covered in the scope of the report, but should be pursued as companion orojects.

- Future technology transfer planning and execution efforts should be technology-sDecific. A clear definition of the research products available for transfer is required. The creation of an inventory of federally develooed design strategies for building energy conservation and tools, components and devices would be invaluable. Each product in this inventory should be characterized in terms of its commercial readiness, market potential and probable adoption. By moving to specifics, the organization and information presented in this report could be better applied and used for olanning specific technology transfer activities.

- A data base of broker orqanizations in the building industry has been compiled by Oak Ridge National Laboratory (ORNL). This data base and the role of broker orqanizations in the technology transfer process should be integrated into the material covered in this report. The linkages and interrelationships with industrv segments should also be specified.

- An overall integration of the models and data bases under development by PNL and ORNL should be undertaken. One vehicle for integration might be a menu-driven computer planning tool that would include the models and data bases identified in this report on an interactive basis. Whatever its form, the integration should provide clear planning direction for technology transfer, and it should take advantage of the knowledge embodied in the models and data bases for each technology and technology market. 

GLOSSARY

Research Utilization

A private/public partnership based on two way communications to transfer technology that meets the needs of industry and satisfies national objectives. Building Enerqv Conservation Decision Process Model

A conceptual model that mads the interactions of decisions related to enerqy conservation opportunities, the participants involved in making those decisions and the criteria employed in making those decisions. The pattern of interactions changes as a function of three primary drivers: ownership characteristics, occupancy/use type and contractina mode. Enerqy Conservation Opportunities

Decision points in the building orocess that affect the quantity and/or pattern of energy use in a building. These opportunities fall into two broad categories: purely design considerations, and materials/components/equipment selection and specification.

Decision Participants

Individuals responsible for the planning, design, specification, construction and use of a building who have an influence on energy conservation opportunities.

Energy Conservation Technologies

The practical applications of knowledge that provide equal or enhanced end use energy services with reduced enerqy input. These applications of knowledge can be embodied in materials, comoonents and equipment, or in a design strategy that inteqrates them.

Industry Segments

Definable qroups of orqanizations related to the building industry that share needs, perspectives and roles in the industry:

Broker Orqanizations

Orqanizations that neither directly produce nor use R\&D results, but are positioned to leverage the resources of both users and producers by maintaining 
effective communications links and by maintaining a sensitivity to the needs of both producers and users.

Transfer Mechanisms

Methods, media and devices that potentiate comnunications and technology transfer. Transfer mechanisms is a general terms that can be disagaregated into media mechanisms, R\&o process mechanisms and policy mechanisms.

Med ia Mechanisms

Transfer mechanisms that provide a channel for written, spoken or visual communications.

R\&D Process Mechanisms

Transfer mechanisms that affect modifications to the process of planning and executing research such that direct communication between users and oroducers of Reo results is enhanced.

Policy Mechanisms

National, state and local dolitical and economic policies that provide incentives to employ advanced conservation technologies.

Information Packages

Discrete arrangements of data and analysis, the content and format of which are consciousiv designed to meet user needs.

\section{Needs Assessment}

A formal activity that results in the orecise delineation of the R\&D and information needs of users of R\&D. Prooerly done a needs assessment will differentiate the needs of each industry segment in the building industrv. 


\section{CONTENTS}

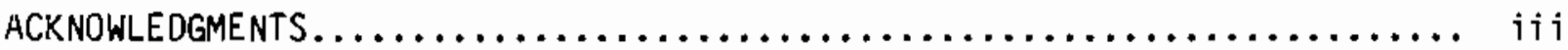

EXECUTIVE SUMMARY AND RECOMMENDATIONS $\ldots \ldots \ldots \ldots \ldots \ldots \ldots \ldots \ldots \ldots \ldots \ldots \ldots$ vii

GLOSSARY................................................. xv

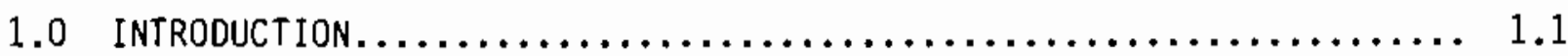

2.0 THE DECISION PROCESS MODEL............................. 2.1

2.1 DECISION SPACE.................................... 2.2

2.1 .1 Predesign Phase............................... 2.4

2.1 .2 Schematic Design Phase....................... 2.5

2.1.3 Design Development Phase....................... 2.6

2.1.4 Bid Process Phase............................. 2.7

2.1.5 Building Construction Phase.................... 2.9

2.1.6 Building Occupancy Phase....................... 2.11

2.1.7 Adaptive Reuse/Reconstruction Phase.............. 2.12

2.1.8 Demolition Phase............................ 2.12

2.2 DECISION PARTICIPANTS................................ 2.12

2.3 DECISION CRITERIA.................................. 2.15

2.4 DECISION PROCESS DRIVERS............................ 2.19

2.4.1 Ownership Mode............................... 2.20

2.4.2 Building Occupancy/Use Mode..................... 2.20

2.4.3 Construction Contract Mode..................... 2.21

2.5 DECISION MATRIX $\ldots \ldots \ldots \ldots \ldots \ldots \ldots \ldots \ldots \ldots \ldots \ldots \ldots \ldots \ldots \ldots \ldots \ldots, 2.22$

2.6 A COMPLETED DECISION MATRIX......................... 2.26

2.7 SUMMARY............................................ 2.30 
3.0 A SEGMENTATION OF THE USERS OF BUILDING ENERGY

CONSERVATION RESEARCH. ................................. 3.1

3.1 LINKAGE WITH THE DECISION PROCESS MODEL................ 3.2

3.2 USER SEgMENTATION....................................... 3

3.2.1 Structure and Crosscutting Data.................. 3.3

3.2.2 Data and Information Sources.................... 3.11

3.3 USER SEGMENTS: DATA AND INFORMATION................... 3.16

3.3 .1 Ownership/Development........................ 3.16

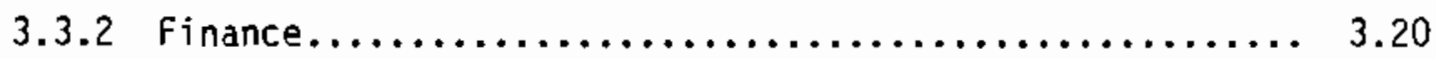

3.3.3 Design and Development....................... 3.22

3.3.4 Construction Contracting....................... 3.29

3.3.5 Materials and Components Manufacturing and Supply...... 3.30

3.3.6 Codes and Standards........................... 3.32

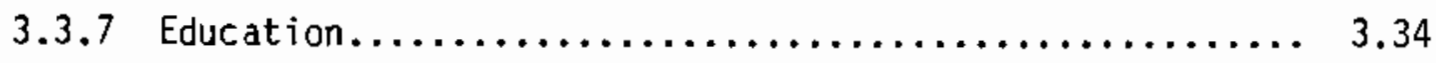

4.0 TEChNOLOGY TRANSFER MECHANISMS AND THE IR ENV IRDNMENT $\ldots \ldots \ldots \ldots \ldots 4.1$

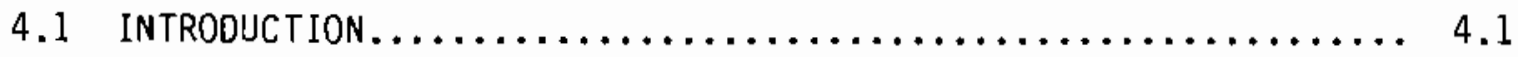

4.2 THE DECiS IDN ENVIRONMENT $\ldots \ldots \ldots \ldots \ldots \ldots \ldots \ldots \ldots \ldots \ldots, 4.2$

4.2.1 The Individual Decision Process................. 4.2

4.2.2 Categories of Decision Makers.................... 4.3

4.2.3 Importance of Interactions Among Decision
Participants................................ 4.5

4.2.4 Technology Diffusion in the Buildings Industry....... 4.5

4.2.5 Why Innovators are Crucial to RU in Buildings........ 4.7

4.2.6 Decision Environment for Innovation Participants...... 4.9

4.2.7 Sunmary of Strategies to Deal With the Decision Environment................................ 4.14 
4.3 Media and Pathway meChanisms $\ldots \ldots \ldots \ldots \ldots \ldots \ldots \ldots \ldots \ldots, 4.14$

4.3.1 Measures of Effectiveness of Transfer Mechanisms....... 4.16

4.3.2 Broker Organization Effectiveness................ 4.16

4.3.3 Mechanisms Available for Technology Transfer......... 4.17

REFERENCES............................................ R.

APPENOIX A: DATA ON SEGMENTS IN CONSTRUCTION CONTRACTING DIVISION...... A.1

APPENDIX 8: OATA ON SEGMENTS IN THE BUILDING MATERIALS AND COMPONENTS

MANUFACTURING ANO SUPPLY DIVISION.................... 8.1

APPENDIX C: SWEET'S CATAlOGUE RECIPIENTS........................

APPENDIX D: PUBLICATIONS FOR BUILDINGS INDUSTRY.................. 0.1 



\section{FIGURES}

2.1 Decision Process Model of Energy Conservation................ 2.2

2.2 Decision Space Energy Opportunities $\ldots \ldots \ldots \ldots \ldots \ldots \ldots \ldots \ldots \ldots \ldots$

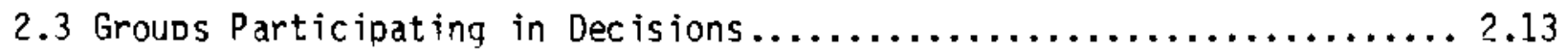

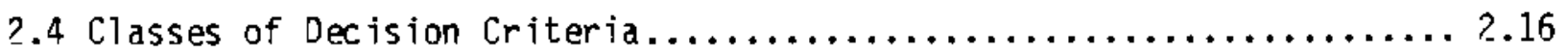

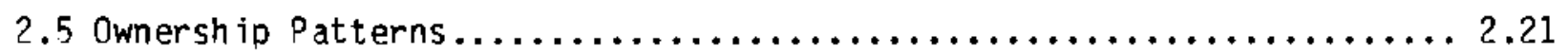

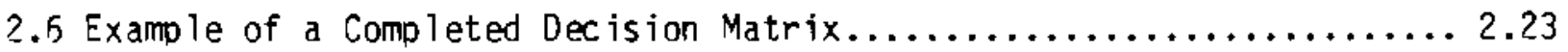

2.7 Decision Particioants Identified As a Result of Industrv Interviews.. 2.?7

2.8 Decision Criteria Identified As a Resu $7 t$ of Industry Interviews..... 2.28

3.11983 Dollar Value Distribution of Construction by Building Type..... 3.5

3.21982 Relative Distribution of Single-Family Construction Receipts.... 3.7

3.3 1984 Relative Distribution of Sweet's Catalog to the Homebuilding

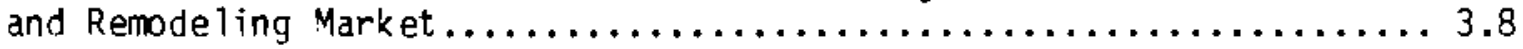

3.41982 Relative Distribution of Dollar Volume in

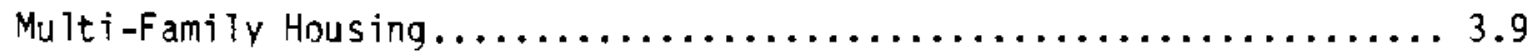

3.51984 Relative Distribution of Sweet's Catalog to the General Building and Renovation Market.......................... 3.10

3.61982 Relative Distribution of Design Professionals............. 3.12

3.7 Relative Growth of Professionals Employed by Firms Enqaqed in Providing Architectura 1 and Enqineering Services, 1977 to 1982...... 3.13

3.8 Summary of 1983 Construction Contracting Division by

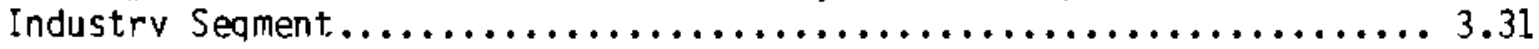

3.9 Materials and Components Manufacturing, Distribution of 1984

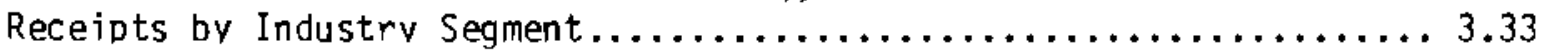

4.1 The Research Utilization Process...................... 4.2

4.2 Characteristic Groups of Techno logy Adopters ................ 4.3

4.3 Transfer Involving Recycle........................... 4.6

4.4 Typical Swings in TechnoTogy Interest Leve $\ldots \ldots \ldots \ldots \ldots \ldots \ldots \ldots \ldots . \ldots 4$ 


\section{TABLES}

3.1 AIA Membership Count as of August $15,1984 \ldots \ldots \ldots \ldots \ldots \ldots \ldots \ldots .27$

4.1 Characteristics of the Adopter Groups.................... 4.4

4.2 A Preliminary Review of Generic Transfer Mechanism Effectiveness.... 4.18

4.3 Media for Target Audiences ............................... 4.21 


\subsection{INTRODUCTIDN}

The Research Utilization Program was created by the Assistant Secretary for Conservation, Buildings Systems Division of the Office of Building Energy Research and Development, U. S. Department of Energy. The purpose of the Research Utilization Program is to promote a systematic approach to technology transfer through encouraging and enabling more frequent and clearer communications between the private and public sectors.

The systematic approach to technology transfer is based on four sets of activities:

- Needs Assessment: Determining the research and information needs of the users of federal building research results.

- Information Development: Transforming raw research resul ts into meaningfut information packages for specific audiences.

- Outreach: Inviting industry participation and disseminating packaged research results through appropriate mechanisms.

- Feedback and Evaluation: Providing for industry and peer review of the RU process and its components and events.

These generic activities cannot be carried out in a vacuum. The RU philosophy recognizes that needs differ according to audience or industry subgroup. Therefore, the subgroups in the industry must be defined.

It is al so recognized that before energy technologies resulting from federal R\&D are adopted, they must be carefully considered by those who plan, design and construct buildings. Therefore, it is important to know how decisions are currently made (e.g., how different building types are chosen), who makes them, and what factors are considered. This can provide insight into the content and format of information to be presented to decision makers.

The issue of outreach is al so important. To make intelligent choices, it is necessary to be aware of the options and the environment. 
An understanding of decision makers information needs is a prerequisite to an effective, efficient approach to technology transfer. The purpose of this report is to provide a base of information to ennance the effectiveness and efficiency of RU activities. The information in this report is organized the following way:

- Modeling the decision process -- Chapter 2.0 provides information on decision spaces, decision participants, decision criteria, and decision process drivers.

- Defining and characterizing potential users of R\&D results -Chapter 3.0 disaggregates the potential users (the building industry and related institutions) into segments and provides data that characterize these segments, enhancing the ability to tailor information to specific audiences.

- Identifying and characterizing effective transfer mechanisms -Chapter 4.0 groups and characterizes media channels and other means of technology diffusion so that information can be transferred effectively.

The decision process model described in this report was developed by PNL with the cooperation of many members of the builings industry. The original version of the model was based on numerous discussions with members of the buildings industry and on an extensive review of the literature. The model was revised a number of times on the basis of feedback from a variety of industry sources. The model was then reviewed by building industry experts at a roundtable conference held in December 1984 and sponsored by the American Society of Heating, Refrigerating, and Air-Conditioning Engineers. Roundtable participants included designers, architects, developers, contractors, trade associations, trade publishers, manufacturers, building code officials and government officials. Based on this review, revisions were made to the decision model. It is anticipated that further revisions and refinements will be made to this model as it is reviewed by other members of the buildings industry. 
Primary information was gathered to help verify the dimensions chosen for the decision process model. This information was collected through a series of telephone contacts with buildings industry members including architects, builders, building associations, and building component manufacturers. A portion of the results of this information collection effort is included in Section 3.6.

The segmentation of the buildings industry and the characterization of industry segments were developed using the open literature. This first level of development has shown that the buildings industry, while large and complex, is understandable. The next level of development would provide further detail on each industry segment, preferably at the firm leve1, so that outreach efforts may be directed toward the portion of the industry segment representing the greatest business volume.

A myriad of barriers impede or prevent the transfer of many technologies from the laboratory to the commercial market, and a variety of these barriers are encountered in the buildings industry. The Energy Division of Oak Ridge National Laboratory has prepared an excellent report (ORNL/TM-9630) highlighting these barriers that have slowed the introduction of energyconserving technologies. The 0ak Ridge report also presents detailed information on the role and strategy of the Research Utilization program by highlighting DOE's current technology transfer activities for the buildings industry. 



\subsection{THE DECISION PROCESS MODEL}

The RU program focuses on the conservation opportunities realistically available to those who own, design, construct or occupy commercial and residential buildings. A large number of complex decisions and actions by interacting participants determine the energy efficiency of commercial and residential buildings. The motives and interests of these participants vary. Some opportunities may not be exploited because of institutional difficulties. Others may be foregone because those who make the critical decisions either lack complete, reliable information or because they do not believe the information they receive. RU focuses on this latter class of opportunities to improve the energy efficiency of the buildings while maintaining/improving the quality of services received by those who work and live in them.

This chapter describes three key dimensions of the decision opportunities available to conserve building energy. This chapter also describes the conditions of ownership, occupancy/use, and construction/contracting mode, which have great impact on the relative importance of the three key dimensions. Those factors that affect the relative importance of the three key dimensions are called "decision process drivers" in this report.

The three key dimensions of the decision opportunities are:

- Decision Spaces - When and where do energy saving decision opportunities occur during the life (conception, construction, use, and demolition) of a building?

- Decision Participants - Who actually makes the decisions (or participates in the decisions) at various stages of a building's life?

- Decision Criteria - What factors control and influence decision making? The dimensions of the decision process are shown in Figure 2.1. These dimensions are discussed in more detail in the rest of the chapter, along with the process drivers which affect the relative importance of the dimensions of the decision model. 


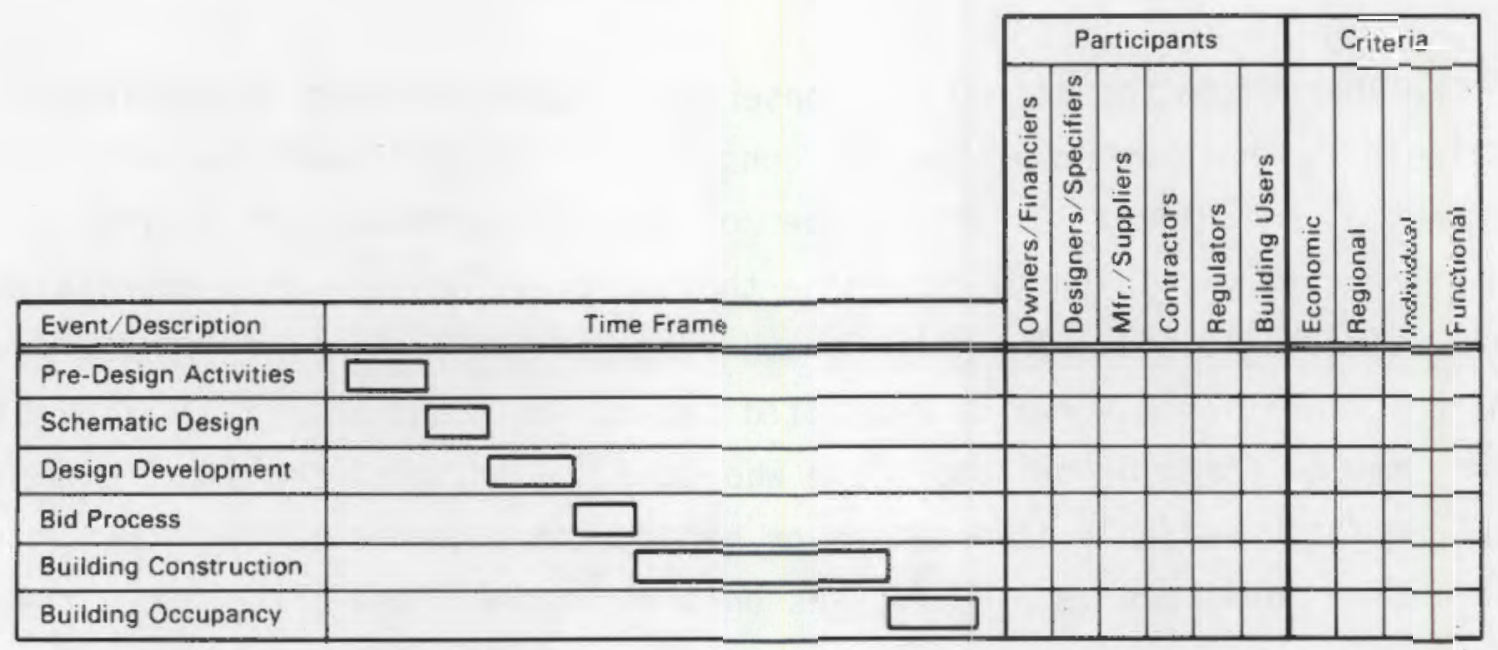

\section{FIGURE 2.1. Decision Process Model of Energy Conservation}

\subsection{DECISION SPACE}

Eneray decision opportunities occur throughout the useful life of a building, from the predesign phase into its occupancy/use phase, as shown in Figure 2.2. Knowing when the opportunities are available can help in the development, preparation and targeting of R\&D results into useful information packages. The decision space, or the oeriod of time in which a given energy conservation decision can be made, opens and closes during the building life cycle. Reconstruction or adaptive reuse presents opportunities somewhat similar to those encountered in new construction (Figure 2.2).

\begin{tabular}{|l|l|}
\hline Event Description & \\
\hline \hline Pre-Design Activities & \\
\hline Schematic Design & \\
\hline Design Development & \\
\hline Bid Process & \\
\hline Building Construction & \\
\hline Building Occupancy & \\
\hline
\end{tabular}

FIGURE 2.2. Decision Space Energy Opportunities 
Great opportunities for improving the energy efficiency of buildings occur in the design phase since nothing has been constructed, and since system components $c$ an be integrated at the highest overall level of efficiency. Materials and labor savings, olus projected operating cost savings can offset, or at least may reduce, the higher initial costs that often accompany energy saving technologies. The level of individual oreference and the desired aesthetics relevant to the occupancy/use of a building can also be optimized at these early phases.

From our discussions with industry we estimate that up to one-third of energy conservation equipment specifications are modified in the bid and construction orocess. Even if energy conserving features are fully implemented in bidding and construction, there are ample opportunities to misuse them or fail to maintain them in later phases of building use. Energy conservation opportunities may occur as a result of normal building remodeling.

The following outline displays the ohases of a building's life and includes some examples of eneray saving opportunities. The outline may imply that there is a straightforward sequence of ohases in a building's life. In reality, this is frequently not the case. Many buildings skip phases, some buildings repeat ohases, and phases frequently overlap. This outline does provide a framework for recognizing and characterizing the types of energy saving opportunities that are available.

\begin{tabular}{|c|c|}
\hline Phase & Energy Saving Opoortunities \\
\hline Predesiqn & $\begin{array}{l}\text { Site selection, building orientation and } \\
\text { feasibility studies, selection of building massing } \\
\text { and fenestration schemes }\end{array}$ \\
\hline Schematic Desian & $\begin{array}{l}\text { Preliminary floor layout, building shape and glass } \\
\text { area }\end{array}$ \\
\hline Design Development & $\begin{array}{l}\text { Lighting, Dlumbing and HVAC designs, selection } \\
\text { of "R" values }\end{array}$ \\
\hline Bid Process & $\begin{array}{l}\text { Acceptance or rejection of substitutions, } \\
\text { alternatives, performance specifications and } \\
\text { standards. }\end{array}$ \\
\hline
\end{tabular}




$\begin{array}{ll}\text { Building Construction } & \text { Use of substitutions to meet critical schedules } \\ & \text { and to substitute for unattainable items. } \\ \text { Building 0ccupancy } & \text { Appliance selection and placement - apoliance } \\ & \text { loads now exceed lighting in many offices; } \\ & \text { use of controls such as occupant sensors. } \\ \text { Adaptive Reuse/ } & \text { Many of the decision opportunities listed above } \\ \text { Reconstruction (a) } & \text { are available; however, it may not be as effic- } \\ & \text { ient to utilize energy conservation technologies } \\ & \text { at this stage as it would be at original design } \\ & \text { and construction. However, unforeseen } \\ \text { opportunities may arise ad hoc. } \\ \text { altemolition (an }\end{array}$

Each of the building phases listed above has a number of associated subphases or activities. These activities may be carried out explicitiy or they may be combined with others. The major decision opportunities for improving the energy efficiency of buildings are ernbedded with in these subphases and/or activities grouped below according to building phase.

\section{1 .1 Predesian Phase}

Major enerqy saving decisions in the predesign phase include:

- Deciding on the location

- Deciding on the size

- Developing the building program

- Deciding on the amenity levels to be provided

- Deciding on the level of financial commitment.

The predesign activities (during which these key decision points are encountered) are provided below:

Ta) Adaptive Reuse and Demolition are omitted from Figures 2.1 and 2.2 for simplicity; however, both phases do provide opportunities. 
Data coordination: the gathering of site data, climatological data, tax information, code and zoning information, etc., for the site and its alternatives.

Market studies (where applicable): the qathering and assessment of demoqraphic and other land use factors necessary to determine whether sufficient demand will exist for the services the proposed buildina can supp ly.

Building orograming: the development of a comprehensive description of the functions, amenity levels, aesthetic requirements, and special needs of the princida1/client, including flow diaqrams of product/personnel.

Facilities surveys: the assessment of the availability of sewer, water, electrical power, rail sidings, and shipoing services, if required.

Feasibility studies: the comparison of a client's needs (from the building program) with the site data and facilities surveys to determine whether the site and facilities meet the client's requirements.

Budgeting process: the development of rough cost estimates and cash flow requirements for energy conservation technologies and a finance availability assessment so that a decision can be made by the orincipal on the advisability of moving to the next phase the preparation of the schematic design.

\section{1.? Schematic Design Phase}

Major enerqy saving opportunities in the Schematic Design Phase are related to:

- External appearance: buildina orientation and shape, surface material, window to wall ratio, external shadina, massing

- Buildinq layout: HVAC space and thermal mass, floor to floor height, ceiling tyoe, conveyances, illumination/daylighting, space allocation.

These enerqy saving opportunities arise in the following schematic design activities: 
Building orogram review: The building proqram will be reviewed and revised taking into account the results of the studies of market potential, feasibilitv, and the budgeting process.

Finalization and aporoval of the building program: The building program is revised several times before it is finalized and aporoved by the client.

Development of a model/elevation drawing: The decisions that affect the exterior appearance frequently have a very larqe impact on energy efficiency of the building. Some of these decisions include setback, orientation, surface to volume ratio, window tc wall area ratio and location, exterior shading, and floor to floor height.

Development of floor iayouts and outline soecifications: Th is step is to let the client know what use can be made of the building - how many tenants can he accommodated, as well as the amenity level that may be provided.

Client review and approval: At th is step, knowledqeable clients can ask for, and economically obtain, changes that will improve the energy efficiency and lower the operating costs of the building. Sometimes this opoortunity is missed because other criteria are of qreater concern at the time.

\subsubsection{Design Deve lopment Phase}

Major energy saving opportunities in the design development phase include:

- Internal appearance: windows/blinds, doors, wall finishes

- Illumination level/lighting efficiency: daylighting controls, fixture selection and location

- HVAC svstem: zoning, sizing of cooling and heatina systems, air quality standards, variable speed fans, selection of heating and cooling system equipment, integrated or separate controls, overall integration with daylighting and lighting levels

- Plumbing: pipe sizes, insulation, waste heat recovery, recirculation systems or dead-ended systems 
- Electrical systems: operating voltages, power factors, appliance loads, bus 1 ayouts, control scheme for lights

- Conveyances: number and placement

- Shell/envelope: structural details, specification

- Thermal resistance values specified for walls, windows, doors, etc.

- Selection of energy sources, fuel trpes.

These energy saving opportunities arise in the following design development activities:

Architectural drawings and specifications: floor plans, window and door details, and finish specifications

Structural design: footings and foundations as well as beams, columns, stringers, and other structural details

Mechanical design and specifications and equipment selection: designs and specifications for heating and ventilation, plumbing, and escalators/ elevators

Electrical design and specifications: location drawings showing outlets and fixtures and control devices such as thermostats and microorocessors for management/operating control svstems, and the coordination of illumination with daylighting

Budget review and aporoval: budget review and approval by the client/sponsor. In this phase the natural tension between capital investment and long-term efficiency of the building is most evident. This tension is often the overriding factor in decisions affecting the energy efficiency of the building.

\subsubsection{Bid Process Phase}

The bid process phase includes the preparation of detail drawings and specifications as well as those activities involved in letting the contracts. Maior enerqy saving opportunities in the bid orocess phase include:

- Preparing budgets, bid packages, detail drawings and specifications and advertisements that include energy savings features 
- Evaluating proposals/selecting contractors who understand energy conservation

- Negotiating substitutions/modifying specifications/finalizing contracts.

Thus, energy saving opportunities arise in the following bid process activities:

Preparation of detail drawings and specifications: These are somet imes neglected or incompletely orepared. Such omisisions can result in expensive change orders/litiqation.

Budget review and approval by the client: Frequentiy the detailing process reveals potential costs that were not previously evident.

Preparation of bid packages: Adequate care results in lower bids from competent contractors/subcontractors, acquiring energy efficient

levels with in competitive biddina.

Advertisement: Allowing adequate time for response is important. If the time for response is short, it is regarded as a strong signal that the contract process is merelv a formality; the ethics of such a practice may be suspect.

Proposal evaluation: This process is made eas"er if sufficient care is used in the preparation of the bid package. Many unacceptable contractors will not bid if adequate information is supplied. The net result can be that fewer inappropriate or ill-prepared bids are received.

Contractor selection: Contractor selection is very important to eneray efficient building construction. The experienced, energy-committed contractor has greater finesse and expertise in employing the necessary techniques and materials, integrating them to produce the desired performance levels in an energy efficient structure. For example, less difficulty will be encountered in achieving low infiltration rates and effective vapor barrier installation if a contractor has had experience with technologies that produce these results.

Negotiation process and modification of specifications: The best contractor for the job frequently will bid alternatives or will not propose to meet all of the requirements. It is in this phase that many energy 
efficient concepts are lost because someone bids lower cost alternatives, and the alternates are accepted bv the client. On the other hand, contractors experienced in construction of energy efficient buildings mav be able to offer very attractive alternatives with the potential of improving the efficiency of the building. This stage of contract negotiation should be viewed as an opportunity.

Budqet review and approval (by client) and contract award: This step completes the bid process phase.

\subsubsection{Building Construction Phase}

There are many ooportunities to improve the energy efficiency during building construction or, on the other hand, to lose some of the expected benefits specified during earlier phases of the huilding orocess. These opportunities are listed below:

- Structural insta1lation methods

- Insulation

- Air/vapor barriers

- Door and window systems

- HVAC installation techniques

- HVAC balancing

- Plumbing installation techniques

- Electrical system installation techniques

- Svstems performance verification

- Conveyance installation and control adjustment

- Inspection/compliance

- Modifications for compliance.

These enerqy saving/loss ooportunities arise during:

Materials orocurement: This is the first activity in which plans and preferences meet realitv. If the specified energy saving equipment/ materials involve deliverv schedules that will delay the completion of the project, they probably will not be used. Delays increase costs through impacts on working capital, increases in Tabor and supervision costs, and lost income from rentals. 
Site preparation, excavation, and installation of foundations and

footings: These activities are often thought of as relatively energy neutral, although below-qrade heat losses are likely to be taken more seriously as other sources of losses are successfully eliminated and as data on the magnitude of the below-grade losses accumulate and are disseminated.

Above-qrade structure and she 11 construction: This activity offers considerable challenge to actually achieve desired levels of insulation and air/vaoor permeability control.

Mechanical and plumbing systems installation: These activities are not usually thought of as having serious energy impact; however, the hot water and steam lines can be larqe energy losers depending on routing, layout, and insutation effectiveness.

Electrical wiring, fixtures and equipment installation: These building systems have widely differing efficiences, and proper zoning can allow for turning off lights when they are not needed.

Convevance installation and adjustment: Conveyances can be selected so that they onerate at very low capacity, or so that part of the equipment can be idled during slow periods allowing for greater energy efficiency of the remainder.

Inspection: These activities, performed hv city, county, and state, can insure that institutional orovisions are met. However, most of the code requirements relate to health or zoning issues rather than to energy efficiency.

In sumary, the contractor can siqnificantly affect the implementation of enerqy saving concepts desired by the owner. The advice qiven by the contractor during the design, procurement and construction ohases is weighed heavilv bv all participants. 


\subsubsection{Building Occupancy Phase}

Maior enerqy savina opportunities in the building occupancy phase include:

- Thorough inspection and testing by the owner

- Acceptance of the building only after performance is verified

- Operations and maintenance procedures prolonging the useful Tife of enerqy saving equipment and the integrity of the structure.

These eneray saving opportunities arise in the following building occupancy activities:

Inspection and testing by the owner: The inspections by the various buitding officials will not necessarilv orotect all the interests of the owner. The building officials are oriented (properly so) toward protecting public welfare. Tests and inspections beyond those performed by these officials are likely to be particularly important to the energy performance of the buildina. For example, the buildina may be comoleted at a time of the year in which there is little stress on the HVAC systems. Since the HVAC load is deoendent on the use of equipment by its future occupants, the owner should test these systems fullv. It is quite difficult to measure vapor vermeability to qive another example of difficulties of testing. Acceptance by the owner: The use of enerqy conserving measures may be limited if they delay occupancy. The owner is usually anxious to move into the new residence or to have tenants move in.

Depreciation and maintenance: All equioment and facilities begin to depreciate at the moment the building is completed. Physical and lega 1 depreciation are, of course, quite different, although they are both irreversible and may temporarily coincide for a soecific building. A properly designed maintenance program can slow the degradation of the building and its equipment. Even the best energy conservation equipment can become inefficient if it is not maintainer properlv.

Leasing and subleasing: The motivations of a tenant are frequently different than those of the landlord. The relationship between the two can be quite comolex and may not necessarilv provide much incentive/opoortunitv for energy conservation. 
Modification of partitions and finishes: In larqe buildings this is a more-or-less continuous process because facility needs change with changes in personnel and with the changing nature of the business. Energv conservation concepts which do not accommodate these changes will not find widespread application. Unfortunatelv, originallv high standards of building performance can quickly disappear during building modification.

Recvcling of leasing and modification steps: This process offers many opoortunities for exoediency, and building performance frequentiy suffers as the building ages and tenants come and qo.

\subsubsection{Adaotiro Reuse/Reconstruction Phase}

Adaptive reuse is being revived and involves most of the steos previously discussed in the above phases, which were illustrated in Figure ?.?. Many of the energy saving opportunities available in new construction are unavailable or are made difficult during adaptive rease or reconstruction. Further investigation of the opportunities of this qrowing field is needed.

\subsubsection{Demolition Phase}

Demolition offers few opportunities for energy conservation, although the decision to tear down a structure has enormous energy implications. The intrinsic enerqy incorporated in materials can be recovered if they can be relused; as materials become more precious, it will become more popular to reuse them. Also, there is an increasingly lucrative nostalqia market for used windows, doors, and fixtures. Unfortunatelv, some of these antiques are very energy inefficient. Demolition sometimes offers qreater opportunity for energy conservation than attempting to retrofit the existing building (adaptive reuse/ reconstruction).

\subsection{DECISION PARTICIPANTS}

The decision to use or to defer energy efficient concepts involves or affects a number of participants: 1) legal owners/*inanciers, 2) designers/ specifiers, 3) manufacturers/suppliers, 4) contractors, 5$)$ requlators, and 5) bulliting users. It is possinle for these cateqories to include only one 
individual or one organization, and decisions frequently involve more than one of the categories of participants, listed in Figure 2.3. Thus, the decision process model shows the influence of decision participants on the energy decisions throughout the phases of the building process.

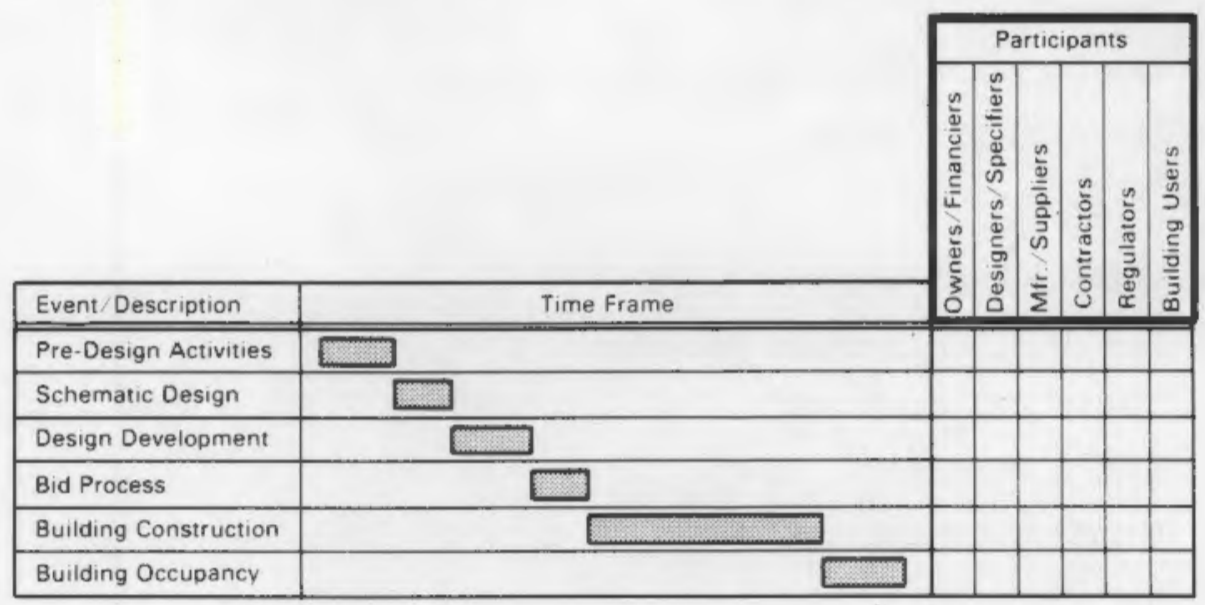

FIGURE 2.3 Groups Particidating in Decisions

Decisions in each phase of a building's life are actually shared by manv different individuals for a variety of reasons. Some participants are chosen because they have soecialized knowledge of the technical area involved. The project may be large enough to make it practical to subdivide it into tasks. The decision may be perceived to be too unimportant for the principal or chief architect. Sharing or delegation of decision making is very common and adds complexity to the task of identifying the key decision makers for a given technical advance.

The list of enerqv conservation decision participants used in this report is divided into six basic cateqories, with each category representing several participating interests:

- OWNERS/FINANCIERS

- Owner/property manager

- Developer

- Real estate broker

- Lending institution

- DESIGNERS/SPECIFIERS

- Architect

- Mechanical engineer 
- Structural engineer

- Electrical engineer

- Energv engineer

- Illumination consultant

- MANUFACTURERS/SUPPLIERS

- Manufacturer/processor

- Distributor/dealer

- CONTRACTORS

- General contractor

- Construction/project manager

- Electrical contractor

- HVAC contractor

- Plumbing contractor

- Roofing contractor

- Conveyance contractor

- Specialty contractor (including all other subcontractor participants)

- regulators

- Zoning aqency

- InsDectors of all levels:

local, state, and federal enerqy commission enforcers

- BUILDING USERS

- Occupant/lessee

- Energy manaqer

- Building/maintenance manager.

The participants in the decision process become involved in one of several ways: 1) they initiate the request or requirement and approve subsequent modifications, 2) they consult, oroviding recommendations/information about the energy conservation concept, 3) they specify the energy conservation conceot on the drawings or in the specifications, and 4) they construct the building, purchasing and installing the materials and equipment. 
These particioants have different needs and viewpoints which influence the way they relate to a new enerqy saving technology. Owners intending to rent out the space after comoletion may be far more concerned with the initial cost of energy saving technology than with the utilitv bills if the terms of the rental agreement call for renters to pay for the utilities. Financing entities are always concerned with the potential resale value if they have to foreclose. They may see new energy saving technologies as negative factors in resale if they escalate initial cost. Architects are concerned with their professional reputation and will have to weigh this factor against the probable effect of a specific project. Similarly, consultants on the project are concerned with the risk to their reputations from advising the use of a new technology.

The contractors will also be concerned with controlling and minimizing construction costs. Any delays or difficulties encountered with new technology will inevitably increase costs and usually will reduce profits. Profits to builders are highly sensitive to the overall length of the construction period due to the working capital they have tied up. If new technology adds to the length of that schedule, contractors will do everything they can to eliminate it, or they will increase their charges accordingly.

Participant concerns are included in the decision process model and are referred to as decision criteria. Research utilization may be accomplished more quickiv if the concerns of participants in the decision process are met by the media and mechanisms employed.

\subsection{DECISION CRITERIA}

The decision criteria used by individuals and organizations involved in the building industry are divided into four classes: economic, functional, regional and individual (see Fiqure 2.4). Each decision participant has several criteria which control and influence energy conservation decision making.

A system was established for classifying each criterion as minor, significant, or major: 
Minor - Indicates that the criterion is considered but is not of primary importance under the identified conditions of ownershipncrupancy/use-construction.

Significant - Indicates that this criterion is important to the decision maker(s).

Major - Indicates that this criterion is important to the decision maker (s).

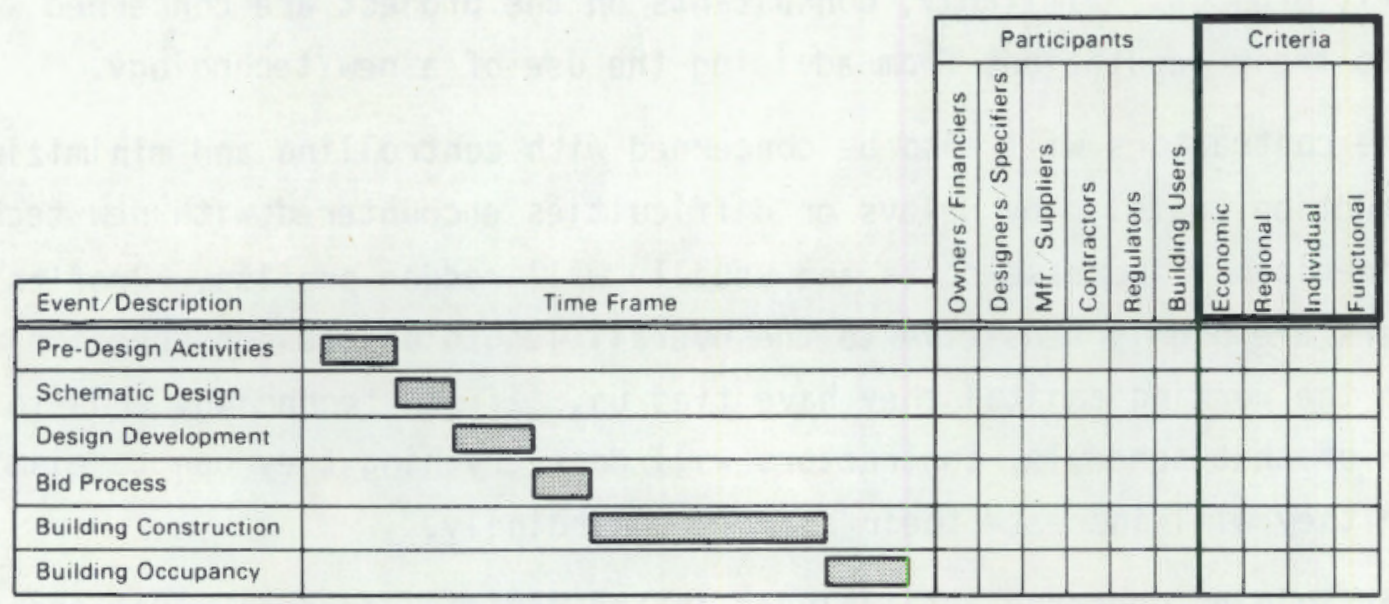

FIGURE 2.4 Classes of Decision Criteria

The criteria for energy decisions are:

- ECONOMIC

- Initial cost

- Payback/return on investment

- Life cycle cost

- Operating cost

- Sale/resale ootential

- Lease potential

- FunCtional

- Ease of installation

- Ease of maintenance

- Ease of operation

- Durability/reliability 
- Flexibility

- Saf ety/health

- Modularity: maintenance/expansion

- Systems compatibility

- REgiOnAl

- Climatic/geographic appropriateness

- Combliance (codes/standards)

- Style/trend

- Availabilitv

- INDIVIDUAL

- Preference

- Professional reputation

- Aesthetics

Uncertainty in the information available to assess these criteria affects the impact of each of the criteria above. Brief descriptions of the manner in which the criteria may be involved in the interactions of an energy conservation decision follow.

Initial cost: Many of the participants are concerned about the initial capital cost of using an energy conserving technology. The owner/resident may choose one technology over another based on relative initial capital costs. These costs include the initial capital outlay as well as any associated tax credits.

Cost effectiveness: Many Darticipants decide to use energy-conserving rather than conventional technologies based on a comparison of their energy saving potentials. Several analytical techniques are available for making this comparison, ranging from simple payback analys is to the more sophisticated life cycle cost analysis including productivity impacts.

Operating costs: A participant may be primarily concerned with the cost of operating a device or system (e.g., costs reflected in monthly utility bills).

Resale potential: The financing institutions and the builders are concerned with building marketability. If the structure has some unique features, the future market for the building may be narrow. 
Lease potential: The parameters of the market audience.

Ease of installation: In some cases the least expensive device to purchase may in fact be the most expensive to install. The device may require structural changes that would delay the construction schedule, or it may require specially trained individuals to install it.

Ease of maintenance: A svstem should require minimum maintenance;

lengthy maintenance downtime is very undesirable. Additional maintenancerelated costs are valid considerations.

Ease of operation: A system must be easy to operate and require a minimal skill, or it will probably not be adopted.

Durability/reliability: Building systems must be able to operate effectively through a broad range of building loads. Only those systems that can operate effectively and that are serviceable and durable will be used. The type or brand name of the device must carry with it the sense of dependability and trust.

Flexibility: The ease with which change is introduced (such as office construction) allows the needs of a variety of clients to be met.

Safety/health: To minimize a buildina owner's liability, a device or system must not be a fire hazard or otherwise dangerous to the building occupants.

Modularity: The selection of a technology may be based on being able to expand the size of the systern with the size or use of the building. For instance, photovoltaic modules can be added in small increments as a building's energy consumption increases over time. Another consideration is modular capability to reduce maintenance downtime.

Systems compatability: If a desired or requested system is not compatible with interacting systems, it may not be effective and functionally efficient.

Climate: Several climatic factors in the preparation and design of a building depend upon geographic location. 
Compliance (codes and standards): The decision to use or to reject an enerqy technoloqy will be based upon compliance with local, state, or federal restrictions, along with other considerations.

Stvle/trends: Styles/trends in buildings and building technology vary from reqion to reqion.

Availability: The system or device must be readily available from a reliable distributor. Any delay in receiving the device will cause delays in building completion.

Preference: Individual requirements and choice.

Professional reputation: A system with a known name or one that has been frequently used in the past is often oreferred over a new, unknown svstem. Decisions to use a new technology that differs from the status quo are made by owners, designers, or builders. Often, these decisions are made with some degree of professional risk. Thus, judgment olus task performance is essential.

Aesthetics: An item may be chosen based solely on its attractiveness. For example, a specially designed window may have more eye appeal than a conventional window.

It is imoortant to understand that not all of these criteria are relevant in every phase of a building's life, nor are they of equal importance to every decision participant. The significance of a criterion depends upon both 1) the person or persons responsible during any given phase in a building's life and 2) the combinations of ownership, occupancy/use, and contracting/construction mode (i.e., "decision process drivers"). These process drivers are important in designing technology transfer initiatives.

\subsection{DECISION PROCESS DRIVERS}

Decision opportunities appear to follow patterns that vary with building ownership, occupancy/use and contracting mode. These parameters, called decision process drivers, may affect the selection of RU strategies. These drivers were identified during industry discussions. 
From our database and the direct feedback from the industry, it appears that as the process drivers change, so do the enerqy decisions. The important decision process drivers are provided below. Verifying these as the definitive categories of process drivers is outside the scope of this investigation.

\subsubsection{Ownersh ip Mode}

The classes of ownership most frequently described include:

- Owner/resident: expects to occupy the structure after it is comoleted.

- Owner/nonresident: (1) exoects to lease the building; thus, the tenant will likely be responsible for operating, and maintenance and utility costs; (2) owner expects to lease building space but will be responsible for operating, maintenance and part or a 11 utilities.

- Developer/speculator: expects to sell the structure to future 1 andlords or occupant/owners.

- Corporate/franchise ownership: expects to occupy the premises but design and investment decisions frequently are made at corporate levels far from the building location.

Different patterns of ownership (see Figure 2.5) result in different degrees of participation in energy decisions, and in changes in the negative importance of the decision criteria. This suggests that research results might be oackaged differently for different owners. Different ownership patterns influence a decision maker's effectiveness.

\subsubsection{Building Occuoancy/Use Mode}

Building occupancy/use patterns can be categorized broadly into three groups: residential, commercial, and institutional.

- RESIDENTIAL

$$
\begin{aligned}
& \text { single family } \\
& \text { multifamily, low rise } \\
& \text { multifamily, high rise }
\end{aligned}
$$




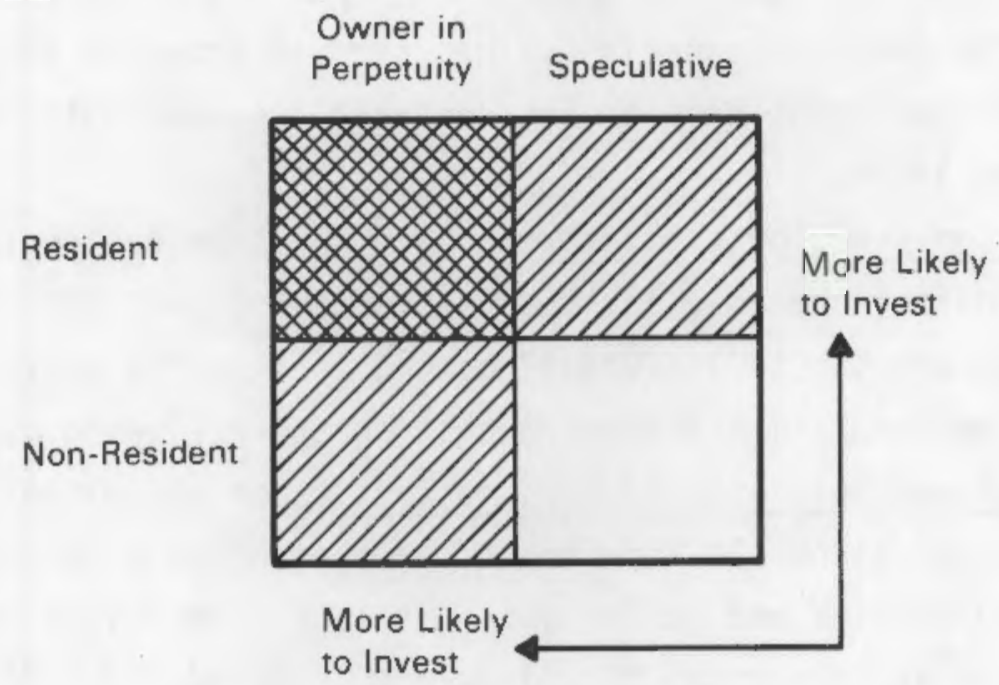

FIGURE 2.5 Ownership Patterns

- commercial

Business, small office and light commercial

Business, large office

Recreational facilities

Warehouse, storage

Retail store, mall, shopping center

- institutional.

Federal, state, county, city

Religious and charitable foundations

Hospitals and nursing homes.

Occupancy/use modes dramatically affect both the effectiveness of the decision participants and the key criteria used in making decisions.

\subsubsection{Construction Contract Mode}

The construction contract mode falls into four groups: design-bid-build, design-build, negotiated construction, and fast track/multi-bid package.

- Design-bid-build is a straightforward process in which the design activities are initially set forth, a bid process is followed, and then the building is constructed by the successful bidder. 
- Design-huild is increasinglv common: this mode eliminates a separate bid process. The owner is usually further removed from the key energy conservation decisions because the contract includes both desian and the construction tasks.

- Negotiated construction contract can have the same design activities as others but differs qreatly in the construction phase. Various parts of the construction are let to individual contractors on the basis of past experience or reputation without accepting and reviewing multiple bids.

- Fast-tracked and multiole-bid package jobs (such as multiole sequential construction of eight-plex apartments or franchised food outlets) introduce several complexities and variations. It is possible that pre-engineered systems, such as in a metal building, are designed and built with no knowledge of what mechanical systems are to be emploved after the purchase and erection of the shell. However, the factory built, precut home or office building may be completely designed and fabricated and may also be supolied with appliances and finishes so that all systems are integrated and coordinated for on-site construction. There are a number of variations of fast-tracked construction and contracting modes.

These modes can represent many of the variations in designing and contracting building construction typically encountered. The importance of establishing the drivers which pertain to any building is that for a specific decision process, the targeting of an audience and the selection of a mechanism for technology transfer hinge upon the particular modes of ownership, occupancy and construction involved.

\subsection{DECISION MATRIX}

In the previous sections, dimensions of the decision process model have been presented. A convenient way of displaying and summarizing the interaction of these dimensions is the decision matrix (Figure 2.6).

The vertical axis of the matrix lists the building phases from predesign through building occupancy. The horizontal axis is a time line that represents the timing and duration of each building phase. Next, the various participants in the decision process are listed, followed by the criteria they consider. A separate decision matrix is completed for each combination of decision drivers (i.e., ownership, occupancy and contracting media). 


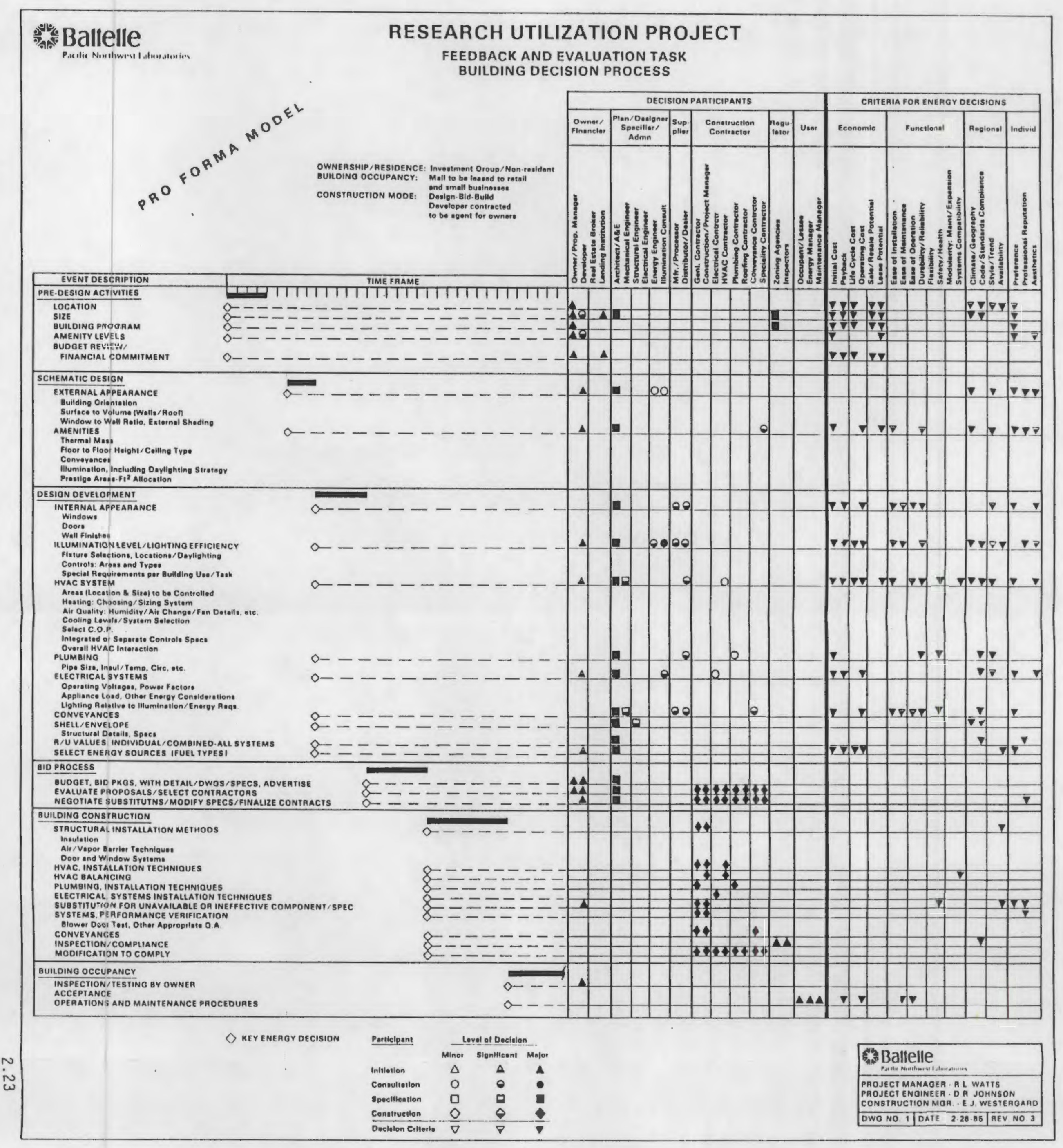

FIGURE 2.6. Example of a Completed Decision Matrix 

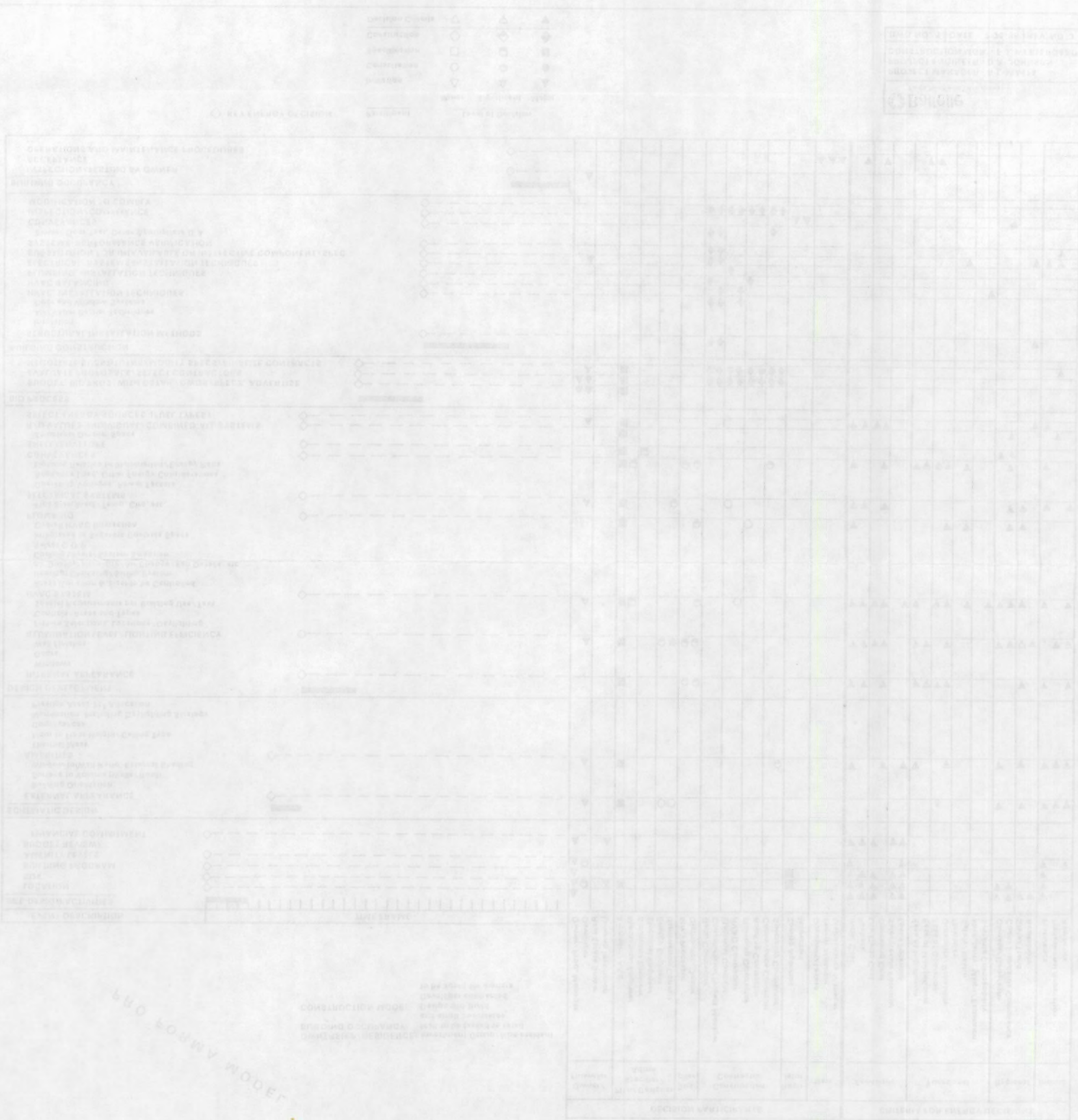
The involvement of a participant in an energy-saving decision is indicated by four symbols $\Delta, 0, \square, \Delta$, representing an initiator, a consultant, a specifier or a contractor. The level of the participant's involvement is indicated by the symbol's shading. The criteria considered by a participant are indicated by a single symbol, $\nabla$, and the level of importance is indicated by the level of symbol shading.

The decision matrix example presented in Figure 2.5 is for the following decision process drivers:

- Ownership/residence: Investment group/nonresident

- Building occupancy: Mall to lease for retail and small business

- Contract mode: Design-bid-build.

This matrix disolays the major participants involved in the decision to adopt or to reject energy-saving technologies for this building. Information used to develop this matrix was gathered from contacts with various members of the buildings industry. Other combinations of process drivers need to be examined in future work.

The information displayed is interpreted by first selecting a building event and activitv, such as Schematic Design and External Appearance. Reading across the page, the participants are identified first. For this activity, the developer initiates the decision to use an energy-saving technology, as indicated by a $\boldsymbol{\Delta}$. The architect/engineer is also involved in an energy-saving decision during this activity, but as a specifier (as indicated by a ...). The energy engineer and the illumination consultant play minor roles during this activity, participating as consultants (as indicated by a $O$ ).

The major criteria that these participants consider in deciding whether to use or reject an energy-saving technology during this builing activity are climate/geography, style/trend, preference, orofessional reputation, and aesthetics (as indicated by a $\nabla$ ).

This chapter presents a structured model and indicates a methodology to help develop tarqeted RU proqrams with the potential of speeding up the diffusion of key technology to those who own, desiqn, build, and occupy residential and commercial buildings. 


\subsection{A COMPLETED DECISION MATRIX}

While developing the decision process model for the building industrv, it was assumed that the decision process was quite complex, that the number of participants varied from phase to phase, and that the criteria considered by participants were a function of the process drivers. To test this hypothesis, data were qathered from the buildings industry, and several decision matrices were completed. These data were collected through conversation with industry personnel. The data collected tended to confirm that the assumptions we had made were correct. However, some results indicated that some of the decision matrices were completed incorrectly.

When we sorted out the definitional problems, we still retained considerable information, which is displayed on the simplified decision matrices that follow. Examples of the results are presented in Figures 2.7 and 2.8. The decision process drivers chosen for this example were:

- Ownership: corporation of professionals

- Occupancy: smal1 office/residence

- Construction mode: design-bid-build.

For simplicity, on $7 y$ two types of participants are noted in these matrices: the initiators are indicated by stars, and all other participants are indicated by vertical bars. The importance of non-initiating participants is noted by the height of the bar, with taller bars signifying greater influence in decisions. An empty cell means that none of the individuals surveyed felt that a given participant was involved in making an energy saving decision during a particular building phase. The nomenclature that was previously oresented identified a participant as an initiator, a consultant, a specifier or a constructor. This may yet be the preferred method for classifying the participation of individuals. However, we believe that the best method for gathering this tyoe of data would be in a workshop setting with building industry members. In such a setting, the questions regarding the proper procedure for completing the decision matrix could be answered.

The criteria used by these participants are also represented by vertical bars. Again, the importance of a criterion is designated by the height of the bar. Emoty cells indicate that none of the respondents 1isted that particular criterion as being considered by any participant for the given building ohase. 
Research Utilization Project

Energy Decisions

and

Decision Participants

in the Building Process

Ownership/Residence: Corporation of Professionals/Resident Building Occupancy Type: Small Otfice Bldg/Business Residence

Construction Mode: Design-Bid-Build

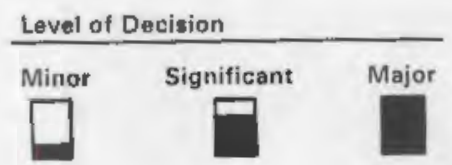

Initiator

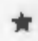

\begin{tabular}{|c|c|c|c|c|c|}
\hline \multicolumn{6}{|c|}{ DECISION PARTICIPANTS } \\
\hline $\begin{array}{l}\text { Own/ } \\
\text { Finance }\end{array}$ & $\begin{array}{l}\text { Plan/Design/ } \\
\text { Specify/Admn }\end{array}$ & \begin{tabular}{|l|} 
Sup- \\
ply
\end{tabular} & $\begin{array}{l}\text { Construction } \\
\text { Contract }\end{array}$ & \begin{tabular}{|l|}
$\begin{array}{l}\text { Reg- } \\
\text { late }\end{array}$ \\
\end{tabular} & Use \\
\hline 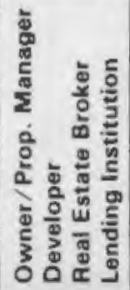 & 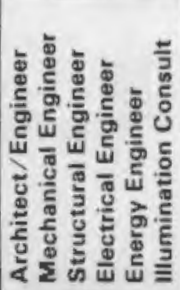 & 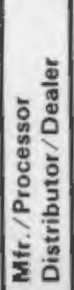 & 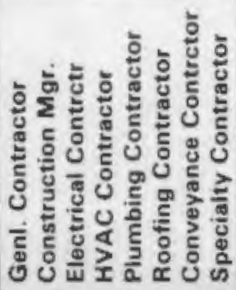 & 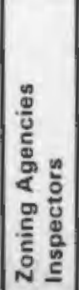 & 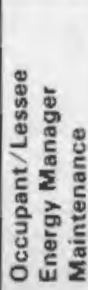 \\
\hline
\end{tabular}

PRE-DESIGN ACTIVITIES

Building Program

Financing

SCHEMATIC DESIGN

External Appearance

Building Layout

DESIGN DEVELOPMENT

Internal Appearance

lllumination Level/Lighting Efficiency

Energy Sources Selection: Fuel Type(s)

HVAC Systems/Integration

Plumbing Systems

Electrical Systems

Conveyances

Shell/Envelope

R/U Values: Individual/Combined: - All Systems BID PROCESS

Budget, Bid Pkgs/Eval. Proposais/Select Contractors

Negotiate Substitutn/Modify Specs/Final Contrcts

BUILDING CONSTRUCTION

Structural Installation Methods

HVAC, Plumbing, Electrical Systems Techniques

HVAC Balancing

Substitutn: Unavailab./Ineffective Component/Spec

Structural/System Performance Verification (Q.A.)

Conveyance Installation \& Operation

Inspection/Compliance: Modification to Comply BUILDING OCCUPANCY

Inspection/Testing/Acceptance by Owner

Operations \& Maintenance Procedures
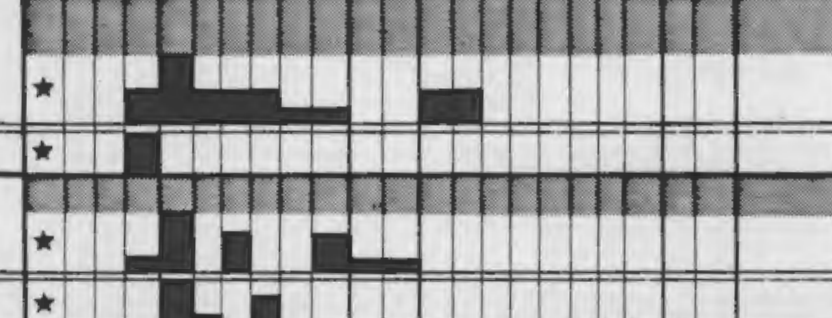

\section{$\star$}

$\star$

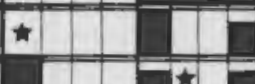

th

$1-\frac{\star}{\star}$

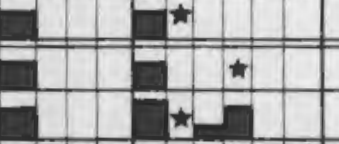

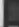
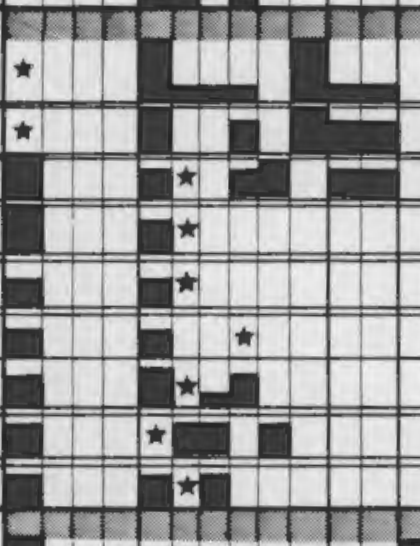

s.
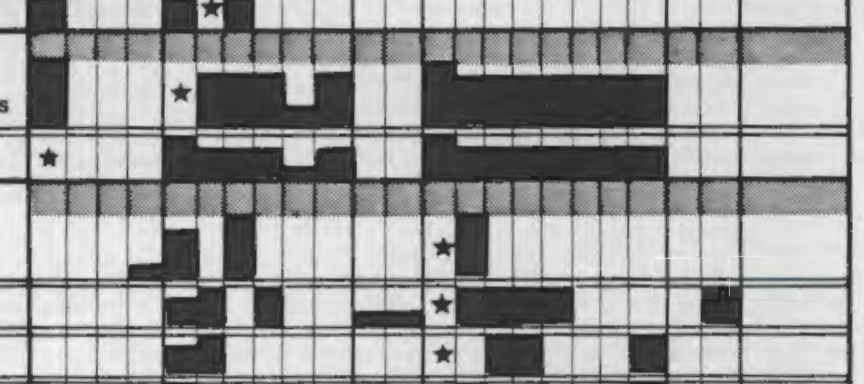


\section{Research Utilization Project Energy Decisions \\ and \\ Decision Criteria \\ in the Building Process}

Corporation of Professionals /

Ownership/Residence: Resident

Small Office BIdg/Bus Residence

Building Occupancy Type:

Construction Mode: Design-Bid-Build

ENERGY DECISION CRITERIA

$\frac{\text { Level of Decision }}{\text { Minor Significant Major }}$

Decision Criteria

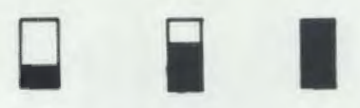

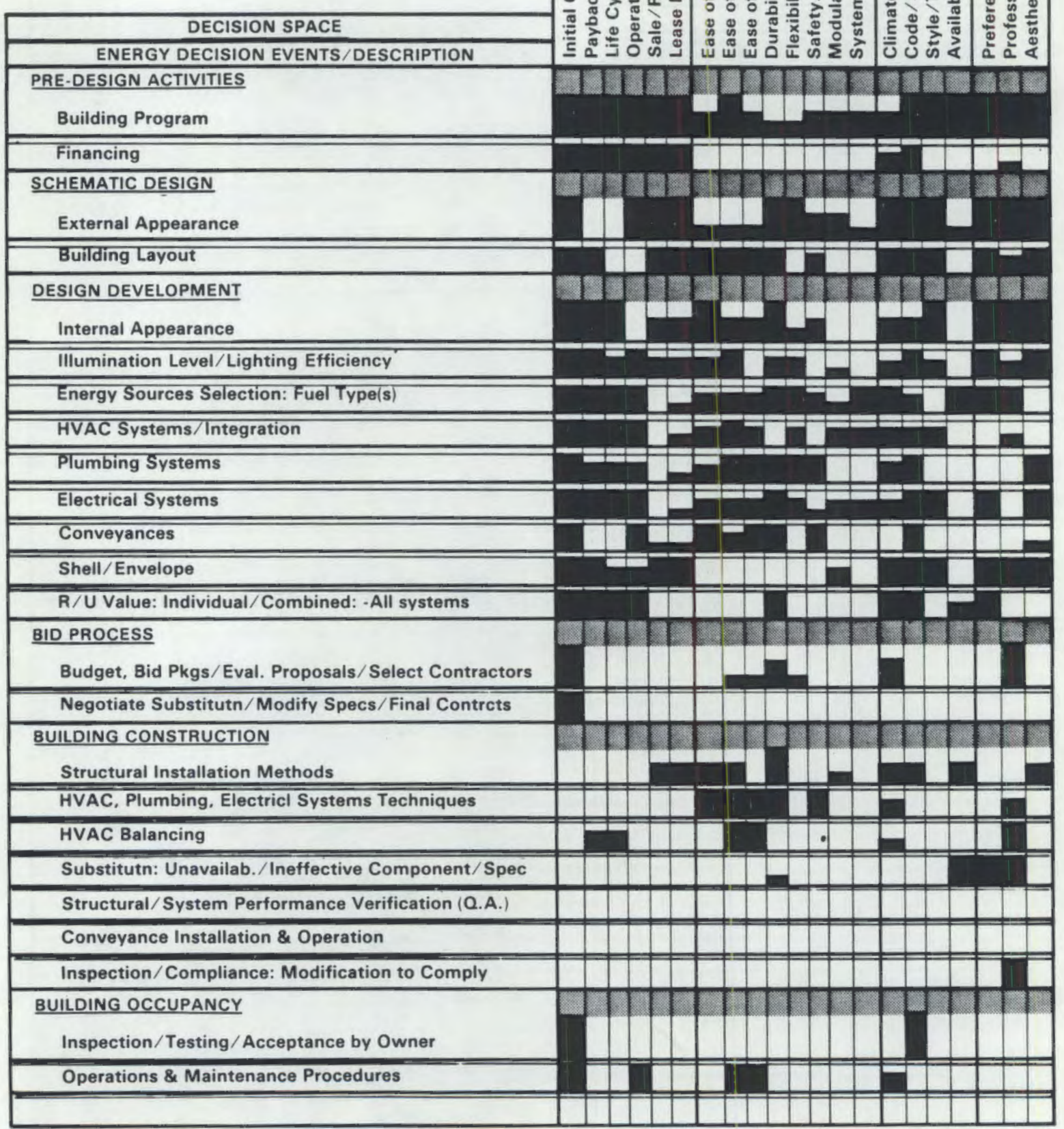

FIGURE 2.8. Decision Criteria Identified As a Result. of Industry Interviews 
A review of Fiqure 2.6 revea 15 the importance of the building owner as the initiator of enerqy saving techniques in the predesign and schematic design building phases. The owner usually selects the location and the orientation of the building, decides on the amenity level, and arranges for financing.

The role of the initiator shifts to the mechanical engineer during the design development phase. The mechanical engineer usually recommends the energy source, the plumbing system, the HVAC system, the conveyances, and the appropriate insulation values. The building owner usually decides the internal appearance and the illumination levels. Selection of the electrical system is usually left to the electrical engineer, and the building shell to the architect. The building owner continues to be influential during the design development phase by having approval or veto power over many decisions.

The bid phase brings the construction contractors into the decision orocess, and they continue to play an important role throughout the construction phase. The general contractor becomes the initiator during the building construction ohase. Each contractor exerts some influence over the decision to use or to reject an energy-saving device or technique, but the ultimate authority lies with the general contractor. In the building occupancy stage, the owner becomes the initiator once again.

Fiqure 2.7 shows the criteria considered by these participants at each building phase. The emphas is during the predesign, schematic design and design development phases is on economic and functional criteria, since the building owner is the initiator or a major participant in these building phases, and since the owner will also be an occupant after the building is completed. In most cases only one or two of the economic criteria listed will be considered by a participant during a buildina phase.

Since the architect is a major participant in the first three building bhases, individual criteria (orincipallv professional reputation) become major considerations. Neither the architect nor the engineer wants to be associated with a building that is an "evesore" or that does not operate proper iy, because of the immediate results and subsequent damage to their orofessional reputations. 
Criteria importance shifts towards the functional as the building enters the construction phase. Ease of installation, maintenance, and operation are of primary concern to the general contractor and other major participants.

In the building occupancy phase, economic criteria are once again considered because the owner will eventually become an occupant of this building.

\subsection{SUMMARY}

The decision to use or reject an energy saving technology in the buildings industry is a very complex process. During any building phase, several participants may be involved using a number of decision criteria. In addition, the combination of participants and criteria can change with the decision process drivers.

A model was developed for describing the relationship between the four dimensions of the decision process, and a method for displaying this information was presented. Data were collected from industry representatives, and samples of these results were presented in the form of completed decision matrices.

One or more workshops should be conducted in which all participants have an opportunity to interact in a forum allowing for clarification of nomenclature and concepts. There is no standard nomenclature operating throughout the construction industry. Different nomenclatures are used by tradesmen, contractors and designers, and reqional differences also are encountered. This workshop could help to solve some of the definitional problems encountered in work to date. The workshop participants would be carefully selected to represent the various participant groups and to ensure that a variety of process drivers were represented.

A key conclusion from this effort is that throughout the life of a buildinq, several individuals simultaneously exert considerable influence in making specific decisions. Thus, they exert de facto veto power over the important enerqy decisions. 
An examole of how to use the type of information presented in Figures 2.7 and 2.8 follows.

Let us assume that it is desired to present information on a new concept for saving energy that affects the external appearance of a building that is owned by a corporation of professionals who will occupy part of the premises.

The information (see Figure 2.7) will need to go to, or be readily available to, the owners and the architect/engineer. Additional decision influences may include the lending institution, the mechanical structural electrical and energy engineers, the illumination consultant, and the general contractor/construction managers.

A number of concerns will need to be recognized and dealt with in the information that is supplied about the new concept. These concerns qo far beyond that which can be dealt with using the usual technical information about the life of the surface, etc. The concerns that need to be dealt with can be identified bv looking at the criteria by which concepts affecting the external appearance are accepted or rejected (see Figure 2.8).

The economic criteria that are most important are the initial cost, the operating cost, sale/resale potential and the lease potential. The most important functional considerations will be durability/reliability and flexibility to meet a variety of future renters' needs. The other functional criteria will also be important. All of the regional and individual criteria will also be important. All of the listed criteria generate concerns that may need to be dealt with hefore the new concept is applied!

There are a number of complex issues involved in selecting the oroper transfer mechanisms for transferring the information to the decision makers shown above and in dealing with the concerns of these decision makers. These issues are discussed in Chapter 4.0. 


\subsection{A SEGMENTATION OF THE USERS OF BUILDING ENERGY CONSERVATION RESEARCH}

The purpose of this chapter is to characterize the users of building enerqy conservation research as discrete market segments, or subsets of the building industry. This enables the targeting of formatted information to appropriate and we11-defined audiences with in the industry. A structure for the segmentation is developed, and data and information on each segment are presented. The relationship between the decision process model and the user segmentation is described in terms of how these tools can be synergistically employed to enhance technology transfer.

The building industry is partitioned into major divisions that correspond to the decision maker archetypes specified in the decision process model. This structure enhances the utility of the decision process model by associating decision makers with industry groups that influence energy conservation opportunities in the real world. Each division is then further divided into industry seqments. Data to help focus the development and targeting of information to the appropriate audience are presented for each segment.

The data presented here represent a beginning rather than a conclusive characterization. The data sources in the open literature rarely present the opportunity to correlate information. Variations in definitions, coverage, scope and accuracy make it impossible to integrate statistics from disparate sources. The structure for disaggregating each industry segment has been motivated partiy by the availability of data, and partiy by considerations of what would be useful to research managers in planning effective technology transfer components to their programs.

Section 3.1 describes the user segmentation as a tool for use with the decision process model, and illustrates the advantages of using the segmentation to target information. Section 3.2 describes the structure and data sources used to develop the segmentation. Section 3.3 and Appendices $A$ and $B$ present data and information on each of the user segments. 


\subsection{LINKAGE WITH THE DECISION PROCESS MODEL}

This section describes how to integrate the use of the decision process model and the user segmentation in planning technology transfer programs. It also describes how the data and information presented for industry segments can help narrow the focus of information transfer to the most appropriate audience.

The segmentation of building energy conservation research users is a tool to be used with the decision process mode1. The decision model maps the interactions of conservation opportunities and decision makers. The user segmentation details what firms and individuals in the industry comprise a category of decision makers. Knowing this is the first step in defining a specific audience that can affect the adoption of an energy conservation technology.

The greatest advantage of segmenting the industry is that it provides the means to focus the targeting of information beyond the first cut of identifying decision maker types with broad divisions of firms and groups of individuals in the industrv. When fully developed, the user segmentation will provide the capability to target information to the most appropriate group of individuals for a given energy conservation opportunity. This group would be much smaller and more manageable in terms of communications than a broad category of decision makers specified in the decision process model.

For example, if the decision model identifies the architect as a key decision participant, the information in the industry segmentation can identify architects who are likely to have the most influence on the adoption of a technology. First, the segmentation identifies architectural firms that specialize in the building type in which the conservation opportunity exists. Second, it locates the area of greatest activity for that type of construction in the nation. From this information, tremendous amounts of resources can be saved that would otherwise be spent trying to reach all architects.

The connection between the decision process model and the user segmentation is that it identifies groups of firms and individual practitioners in the building industry that are portrayed in the model as decision makers. The advantage of segmenting the industry is that it provides the ability to target information to those subsets of firms and individuals that represent the greatest potential for adopting energy conservation technologies. 


\subsection{USER SEGMENTATION}

The overall structure of the segmentation is presented in this section. Information on the geographic distribution of firms and construction activity and information on the distribution of construction activity by building type further defines the structure. This information apolies across major divisions in the segmentation. Issues associated with the collection, analysis and presentation of data on industry segments are discussed.

The importance of segmenting the potential users of building research is that each segment performs a distinct functional role in the building process. Each segment has different decision criteria, information needs and sources, and customary formats. Segmenting the industry allows research managers to more sharply focus technology transfer programs.

\subsubsection{Structure and Crosscutting Data}

The major divisions corresponding to decision maker archetyoes in the decision process model are as follows:

- Ownershio/Development

- Finance

- Desian and Development

- Architecture

- Engineering

- Materials and Components Manufacturing and Supply

- Construction Contracting

- Code Officials

- Building Operation

- Education.

A useful framework for disaggregating industry segments with in these major divisions is by building use type. This allows for more focused targeting of information on technologies that troically apply to specific building tvpes.

Detailed information on firms that specialize in certain building types is available for major portions of the Design and Development Division. ProFile, the directory for the American Institute of Architects, provides approximate percentage distributions of business volume by building type for each 
member firm. The membership directory for the American Council of Consulting Engineers provides a similar, though less detailed, breakdown.

Figure 3.1 provides a means to gauge the relative activity of design professionals and construction contractors according to building use type. The average dollar volume of new building construction for the years 1981 through 1984 is given by building use type. This represents appproximately $70 \%$ of all new construction, the remainder being non-building construction (highways, telephone and telegraph, mining structures, sewers, etc.).

The relative levels of activity shown in Figure 3.1 give a rough breakdown of the percentage of activity in each segment. The limitations to using this gauge are that the non-building and industrial portions of construction activity are not included, and that the relative involvement of any given industry segment varies from building type to building type.

However, no other data sources were found, other than the membership directories mentioned above, that differentiate firms by the type of buildings they design or construct. These limitations can be addressed qualitatively by making some reasonable assumptions. It is reasonable, for example, to assume that engineering services for industrial and some non-building projects would be fairly intensive, and that architectural services for those categories would be less intensive. For the categories listed in Figure 3.1, both architectural and engineering services would be less intensive for single unit houses than for offices, or other commercial buildings. Non-residential farm buildings would be even less intensive.

These contraints limit the ability to quantitatively disaggregate industry segments by building type specialty. However, this does not preclude the qualitative application of segmentation by building type. This allows for further delimiting a target audience.

A second dimension for disagaregating industry segments is geography. This is particularly helpful for prioritizing support for broker organizations such as state energy offices, local chapters of national orqanizations, etc. Potentiating the technology transfer activities of local industry associations takes advantage of existing communications channels and trusted relationships that 


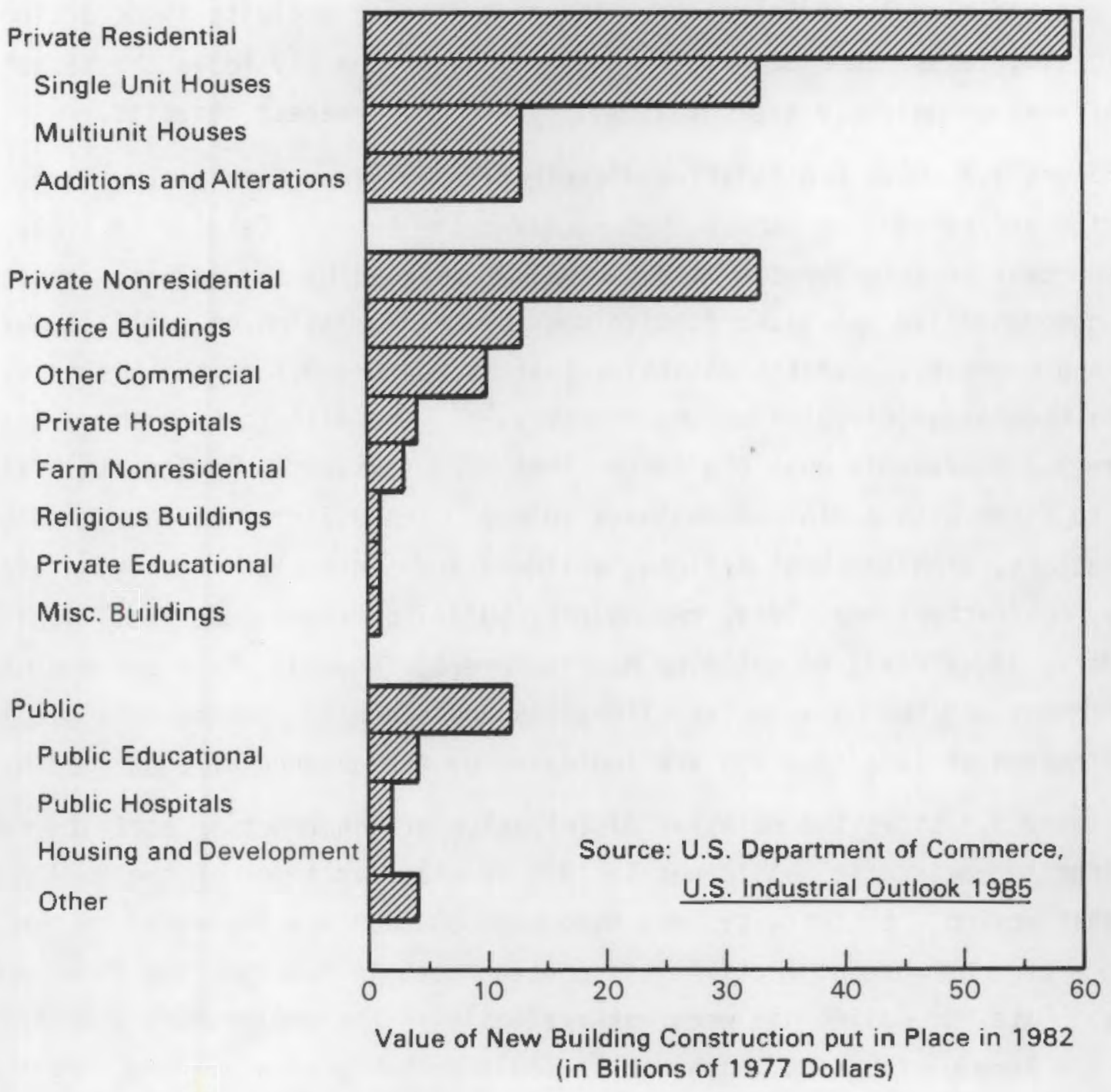

FIGURE 3.1. 1983 Dollar Value Distribution of Construction by Building Type 
have been established over time. This leverages the impact of federal technology transfer resources. Figure 3.2 shows the relative distribution of single family dwelling construction activity for 1982 in terms of dollar value. States with less than $\$ 800,000,000$ are indicated by the ahsence of a bar araph. This graphic clearly indicates that the most intense activity is occurring in California, Texas and Florida. This allows us to sharply focus the targeting of information on those areas that will yield the areatest benefits.

Figure 3.3 shows the relative distribution of firms serving the homebuilding and remodeling market that received the Sweet's Catalog in 1984. This is important because Sweet's is universally regarded by the industry as the most comprehensive and authoritative source of information on building materials and products. Sweet's maintains that it reaches $95 \%$ of the business volume in the design division of the industry. (a) The distribution shown in Figure 3.3 represents only the large firms because Sweet's limits its distribution to firms with a minimum business volume. These firms include builders and contractors, architectural offices, builders and contractors employing architects, contractor remodelers, remodelers, building material dealers, dealerbuilders, industrialized building manufacturers, federal, state and municipal departments and buying agencies, libraries and schools. States with catalog distribution of less than 400 are indicated by the absence of a bar graph.

Figure 3.4 shows the relative distribution of construction activity for multifamily residential buildings in 1982 by state in terms of the dollar value of construction. States with less than $\$ 200,000,000$ are indicated by the absence of a bar graph. Activity is concentrated in Florida, New York, and Texas. Data for California were not available in the preliminary statistics from the Bureau of Census, although it would probably be a primary target also.

Fiqure 3.5 shows the relative distribution of firms engaged in the general building and renovation market that received Sweet's Catalogue in 1984 . Since the residential and industrial markets are listed separately for catalogue distribution, this is a good representation of large firms engaged primarily

(a) Personal communication with Miriam Eldar, Sweet's Division, McGraw-Hill Pub lishing Company, New York, New York. 



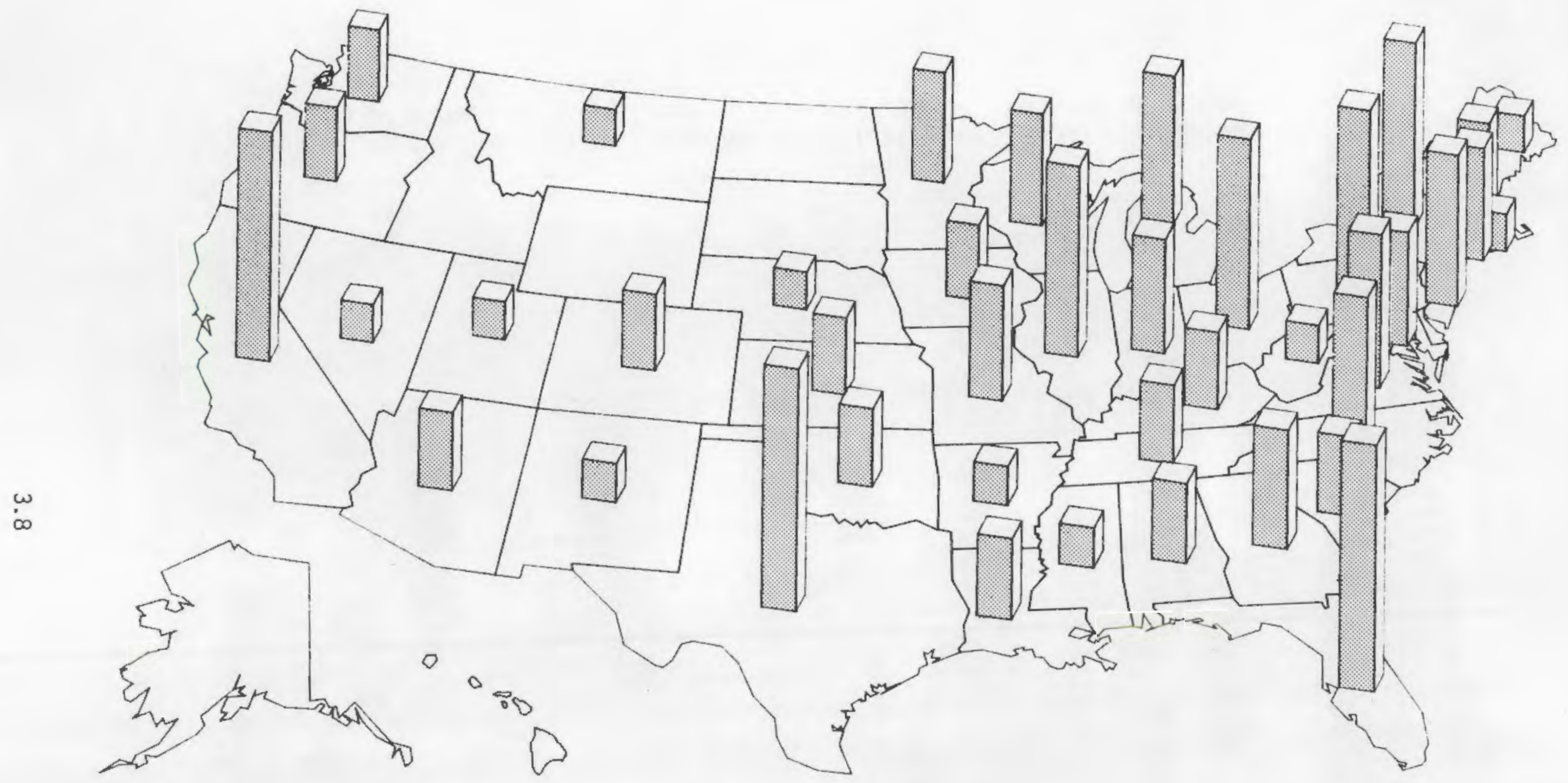

FIGURE 3.3. 1984 Relative Distribution of Sweet's Catalog to the Homebuilding and Remodeling Market (Sweet's Division, McGraw-Hi1l Publishing Company) 


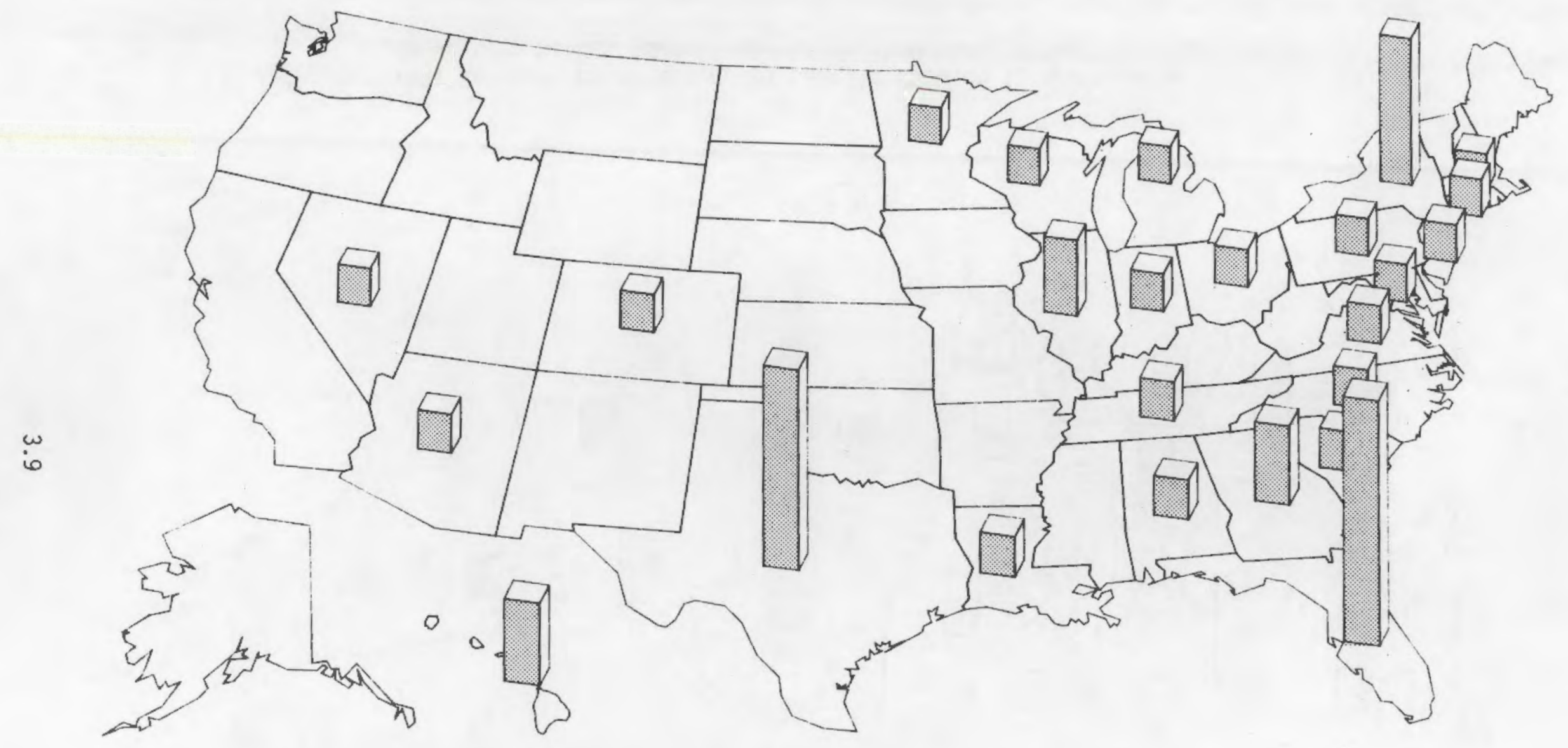

FIGURE 3.4. 1982 Relative Distribution of Dollar Volume in Multi-Family Housing (U.S. Department of Commerce, Bureau of Census, 1982 Census of Construction Industries - Prel iminary) 


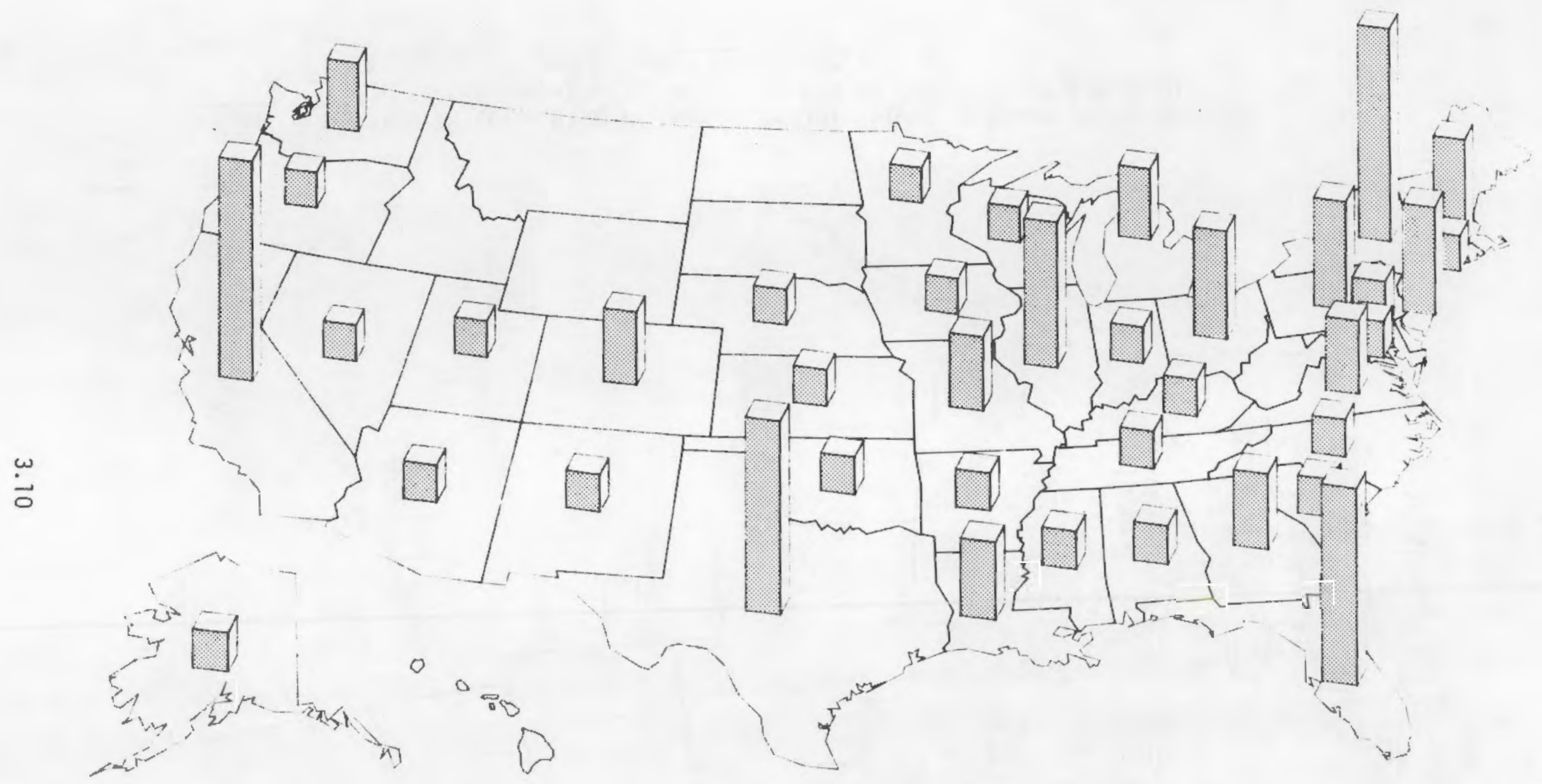

FIGURE 3.5. 1984 Relative Distribution of Sweet's Catalog to the General Building and Renovation Market (Sweet's Division, McGraw-Hill Publishing Company) 
in the commercial market. States with catalog distribution of less than 400 are indicated by the absence of a bar graph. Included in this distribution are architectural offices, architectural and engineering offices, general contracting firms emoloying architects, contracting companies employing architects and engineers, specification consulting firms, building design engineers, consulting engineers, engineering and general contracting firms, general contracting firms, construction management firms, state and municioal departments and buying agencies, corporate building departments, schools, libraries and plan rooms.

Fiqure 3.6 shows the 1982 relative distribution by state of employees in firms engaged in providing architectural and engineering services. States with less than 12,000 employees are indicated by the absence of a bar graph. Some care should be exercised in interpreting this data for three reasons. First, many architects and some engineers are not accounted for because they are sole proprietorships. Second, these data do not distinguish among building types (industrial vs. non-industrial) or between building and non-building construction. Third, many of these employees are engaged in the design and management of foreign construction projects, which account for $15 \%$ of billings for the top 500 design firms (U.S. Department of Commerce 1985). Despite these limitations, this information is useful for indicating where the concentrations of design professionals work.

Figure 3.7 shows the relative growth in number of emoloyees in firms engaqed in providing architectural and engineering services between 1977 and 1982 . Since this graphic is derived from the same data used in Figure 3.6, it has the same limitations. It is, however, useful for tracking growth in absolute terms.

\subsubsection{Data and Information Sources}

The open literature oresents a formidable challenge in gathering useful quantitative information at the industry segment level. Data are usually presented at a level either above or below that of the industry segment. Furthermore, industrial and non-building construction projects are often lumped in with commercial and residential building projects. And finally, the professional association memberships used include both building and non-building construction personnel. 


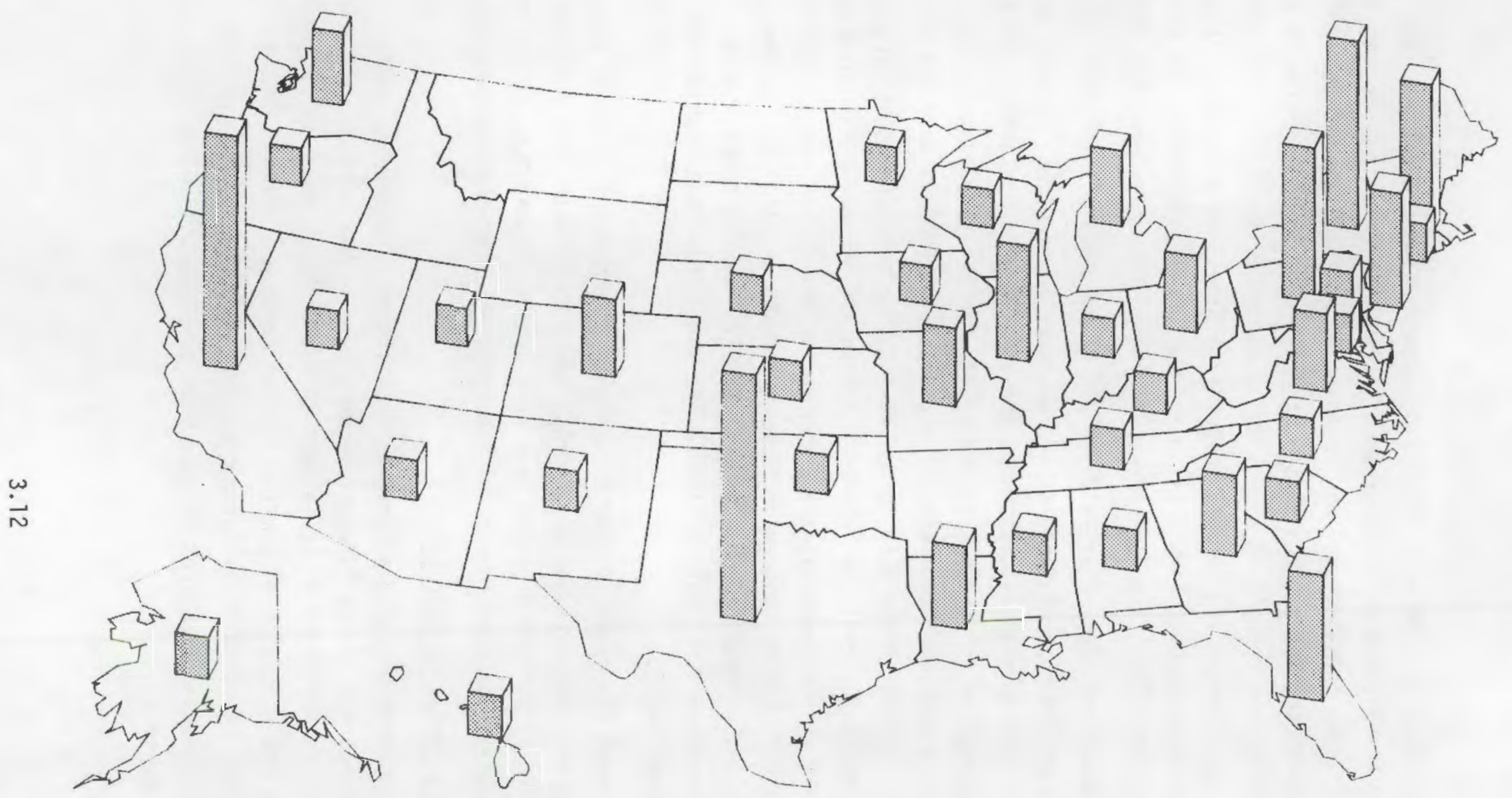

FIGURE 3.6. 1982 Relative Distribution of Design Professionals (U.S. Department of Conmerce, Bureau of Census, 1982 Census of Service Industries - Preliminary) 


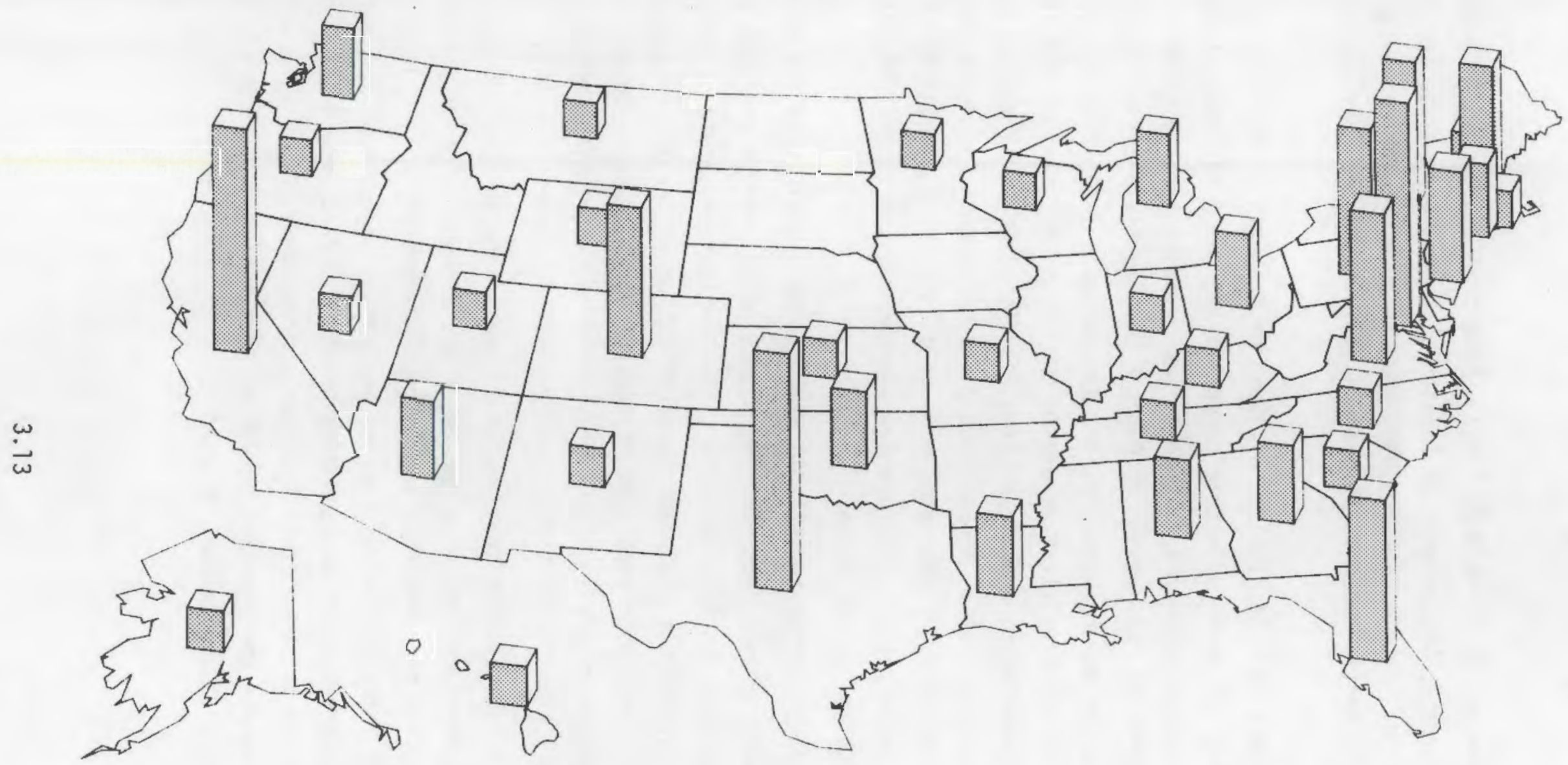

FIGURE 3.7. Relative Growth of Professionals Employed by Firms Engaged in Providing Architectural and Engineering Services, 1977 to 1982 (U.S. Department of Commerce, Bureau of Census, 1982 Census of Service Industries - Preliminary) 
The data presented in Appendices $A$ and $B$ have been aggregated from the U.S. Department of Commerce, the Bureaus of Industrial Economics and the Census, and the open literature. Some data from these sources have been extrapolated and/ or interoolated to derive information that is useful in characterizing industry segments.

Through its catalog file, Sweet's Division of McGraw-Hill Publishing Comoany maintains a vital transfer mechanism by linking building products manufacturers with the design community that specifies building materials and products. Quantitative information on Sweet's Catalog distribution is presented in Appendix $C$ for two reasons. First, as mentioned in Section 3.2.1, the catalog reaches $95 \%$ of the dollar volume in the design division of the industry: This comprehensive coverage qualifies its distribution as a good indicator of geographic distribution of business. Second, Sweet's segments the design communitv differently from both this study and the U.S. Department of Commerce. This segmentation structure can provide additional insight into information tarqeting in some cases.

The Uniform Construction Index (UCI) provides an organization for the materials and components of manufacturing and supply divisions but provides no data on the firms that comprise this division. The American Institute of Architect's (AIA's) Masterspec system and the organization of Sweet's catalog are variants of UCI. This index does show the extent to which each segment in the materials and combonents division could be further disaggregated, which might be helpful in tarqeting information on very specific research results.

A statistical data base on portions of the buildings industry is maintained by the U.S. Department of Commerce, Bureau of the Census. This data base is valuable for tracking the construction contracting segments of the industry. The materials and components manufacturing and supply segments of the industry in this data base are classified according to the Standard Industrial Classification (SIC). While this structure aggregates production of goods in ways that do not reflect the way the industry perceives market divisions, the quality and comprehensiveness of the data make it useful. 
A final primary data source is the U.S. Department of Commerce, Bureau of Industria) Economics (BIE). Most of the information in Appendix $A$ is derived from BIE's Industrial Outlook series and from the Bureau of Census' Census of Construction Industries (preliminary). These data are organized as follows:

- Number of establishments: Establishes a reference ooint for the extent of coverage necessary to achieve full market penetration for pertinent information.

- Number of establishments with 20 or fewer enployees: Gives some indication of the size distribution of firms. If the tvpical firm in the industry segment is sma11, the targeting of information is simpler than if the typical firm is large and comblex.

- Percent of industry shipments accounted for by 4 largest firms: Gives an indication of the concentration in an industry segment. If the level of concentration is high (as it is, for example, for the glass manufacturing industry segment), the most effective strategy is to tarqet information directly to the largest firms. This allows for an economy of federal resources for technology transfer.

- Total emoloyment: Provides a bench mark for the number of individuals who must receive and understand information on research results to achieve ful1 coverage. This statistic must be tempered by the fact that not all employees in a given industry segment have the authority to exercise influence over energy conservation decisions.

- Value of industry shipments: Especially vis-a-vis other industry segments, these data provide a reference for the relative business influence over the decision making process exerted by the industry segment.

- Value added: Provides a reference for wages and salaries paid in an industry segment.

- Major producing states: Provides an idea of geographic concentration of an industry segment, allowing for hetter targeting of information, particularly if state and local broker organizations can he employed to leverage federal resources. 


\subsection{USER SEGMENTS: DATA AND INFORMATION}

This section provides statistical data and information on trends and market factors that impinae on ways to effectively transfer information to specific segments of the buildings industry. Each subsection may be regarded as an introduction to the segmentation within a maior industrv division. The orevious discussions on the distribution of firms according to buildina use trpe and according to geography generaliy aboly to each segment described below.

\subsubsection{Ownershio/Development}

Owners are nearly always the strongest potential influence over decisions that affect energr conservation opoortunities. Their actual influence varies not only with the factors soecified in Fiqure 2.5 , but also with the number of principals that compose the ownershid function, and with their personal degree of involvement in the building process.

Building owners are the most diverse grous in the industry, ranging from corporate entities to professionals to investors. This diversity is illustrated by the following sumarv prepared for the Federal Eneray Administration (Booz, Allen and Hamilton 1985).

\section{Education}

- Highty diverse: 6th grade to PhD, technical and non-technical

- Masters degrees in business and finance most common

- Generallv the larger the ownershin, the areater the education.

\section{Experience}

- Highiy diverse

- Varies with size of ownership

- On the average, related experience tends to increase with company size.

\section{Operational Methods}

- Varies with size of ownership, building type, size and use, and number of tenants

- On the average, division of Tabor increases with company size 
- Operational functions include:

- aenera 1 management

- administrative and lega 1

- finance

- marketina

- production.

\section{Professional Methods}

- Relate to operational functions and include:

- technical guidance

- technica 1 expertise

- earnings/income

- new business opportunities

- Degree to which he or she relies on outside expertise (either within his or her own firm or by contractors) varies with company size and magnitude of holdings.

Developers' potential influence varies bv the deqree to which they have invested in the oroject. Developers are an independent groud whose overriding ourpose is to broker the elements necessarv to create a building in response to a oerceived need. Their independence is evidenced by the nature of their service, and by the fact that, Hespite their inclusion as a reoorting category, limited data are available from the Census of Construction Industries.

The following industrv seaments are included in the ownership/development division:

- corporate owners

- owners with commercial franchises

- operative builders

- other owners

- commercial developers

- real estate brokers

This taxonomy is not fullv developed due to a lack of data on the various owner types. Real estate brokers are included here because they directly represent building owners, and because they can influence energy decisions by assessing the salability of a building. 


\section{Cornorate Owners}

This segment refers to corporations, stereotyoically large corporations, that own and operate sianificant real estate holdings. These are distinguished from other segments because they usualiy employ in-house staff to plan, design and develop their buildings. Corporate decision making is more formal and complex than other situations. Several levels of management might be involved. Large corporations typically have energy managers that oversee (usually with no line authority) all building operations. No statistics are available for this segment.

\section{Owners with a Commercial Franch ise}

This tvpe of owner is segregated from others because of the significant arowth in franchise operations, and because the franchising organization may play a major role in recisions that affect energy conservation opportunities. In 1985, 481,000 franchise establishments will account for sales of $\$ 459$ billion (U.S. Deoartment of Commerce 1985; Hotel and Motel Management 1984). Sophisticated franchising firms like McDonald's Restaurants not only have considerable influence over the desian of buildings, but also conduct their own energy research and offer professional design services. Franchising firms using commercial buildings for operations offer a unique opportunity to reach many building owners through an existing infrastructure.

\section{Dperative Builders}

Establishments in this industry segment are engaged in the construction of single family houses and other buildings for sale on their own behalf rather than as contractors. This includes speculative builders and condominium developers.

\section{2}

Total Number of Establishments

14,045

Total Number of Establishments with $N / A$ 20 or Less Employees 
Percentage of Industry Receipts Accounted

for bv 4 Largest Firms

Total Employment.

108,253

VaTue of Industry Receipts

$\$ 15.8 M M * *$

Value Added

$\$ 5.7 M M$

** \$6.7MM of this was subcontracted out.

Maior Producina States: $T X, C A, F L$

Source: 1982 Census of Construction Industries (prelim.)

\section{Other Owners}

This seqment represents the vast majority of building owners. It is defined simoly to include the diversity of ownershio described at the outset of this section. No further statistical analvses were found to characterize this seqment.

\section{Commercial Developers}

Establishments in this industry seqment are enqaqed in subdividing real prooerty into lots, except cemetery lots, and in developing it for resale on their own hehalf.

\section{2}

Tota 1 Number of Establishments

5,036

Total Number of Establishments with

N/A

20 or Less Employees

Percentage of Industry Receipts Accounted

$N / A$

for by 4 Largest Firms

TotaT Employment

41,577

Value of Receiots

$\$ 2.2 M M$ 
Major Producing States: TX, FL

Source: 1982 Census of Construction Industries (prelim.)

\section{3.? Finance}

Major seqments of the real estate finance industry are as follows:

- Savings and Toan associations

- mutual savings banks

- real estate investment trusts

- mortaage comoanies

- commercial banks

- Tife insurance combanies

- pension funds

- qovernment orograms

- unconventional sources.

Although the influence of financiers on conservation decisions can be significant, detailed information on every seqment of the finance industry is bevond the scope of this report. The following sumary is orovided. Savinas and Loan Associations

SIC 612

Number of Associations *

Number of Branches *

Number of Offices *

Employment $(000)$

Assets ( $\$$ billions)

Mortaages (\$ billions)

Total Savings (\$ billions)
3,391

18,060

21,451

395

590

640 
* As of September 30,1982

Source: Federal Home Loan Bank Board and Bureau of Labor Statistics, as reported in 1984 U.S. Industrial Outlook, U.S. Department of Commerce 1984.

Life Insurance Companies

SIC 6311

Premium receipts (billion \$)

Emplovment $(000)$ *

Number of Combanies

* Home office on ly.

Source: American Council of Life Insurance and Bureau of Labor Statistics, as reported in 1984 U.S. Industria? Outlook, U.S. Department of Commerce 1984 .

Distribution of Life Insurance Company Assets, by Type, 1983

\begin{tabular}{lcr} 
Assets & $\begin{array}{c}\text { Value } \\
\text { (billion \$) }\end{array}$ & $\begin{array}{r}\text { Percent } \\
\text { of tota }\end{array}$ \\
\hline Corporate securities & 280 & 42.3 \\
$\quad$ Bonds & $21 ?$ & 32.0 \\
Stocks & 68 & 10.3 \\
Mortgages & 149 & 22.4 \\
Policv loans & 55 & 8.3 \\
Government securities & 68 & 10.3 \\
Real estate & 22 & 3.3 \\
Miscellaneous & 89 & 13.3 \\
$\quad$ Total & 653 & 100.0
\end{tabular}


Cormerc ia 1 Banks

SIC 60 ?

Number of banks *

Number of Branches *

Number of Offices *

Emp loyment (000)

Assets (\$ billions)

Loans (\$ billions)

Investments (\$ billions)

Deposits (\$ billions)

* 1982 year-end data.
15,031

39,775

54,806

1,530

1,966

1,061

414

1,498

\subsubsection{Design and Development}

The desian and development community is comprised principally of architects and enqineers, although general and specialty contractors become involved in the design process from time to time. These professions specifv what equipment and materials will be used in a building, their sizes and capacities and how they will be used in terms of buildina geometrv and configuration.

A major source of potential confusion in the professional design division is the lack of one-to-one correspondence between professional functions and fim tyoes. Any or all of the firm types listed below may employ any or all of the professionals listed. While it is the people who make the decisions regarding energy conservation opportunities, often the only identifiable way to reach them is through the firm. 


\begin{tabular}{ll} 
Firm Type & Professiona 1 Title/Function \\
\hline Architectura 1 & Architects \\
Landscape-architectura 1 & Landscape architects \\
Architectural engineering & Civil engineers \\
Engineering-architectural & Structural engineers \\
Interior design & Mechanical engineers \\
Corporate design and development & Electrical engineers \\
General contracting & Design technicians \\
& Interior design consultants
\end{tabular}

The following is a statistical summary of the portion of the design community conducted by the Bureau of the Census in SIC 891 , enqineering, architectural and surveying services. As discussed previously, sole proorietorshios, a significant portion of this industry division, are not counted in these statistics. Establishments in this industry segment primarily perform services of a orofessional nature in the fields of enqineering and architecture. Enqineering services relate to both construction and nonconstruction services.

1982

Total Number of Establishments

$75,583 \star \star$

Total Number of Establishments with

N/A

20 or Less Employees

Percentaqe of Industry Receiots Accounted

$N / A$

for by 4 Larqest Firms

Total Employment

566,517

Value of Industry Receiots

$\$ 33,532 \mathrm{MM}$ 
Value Added

* For disaggregation and some detail, see writeup in text

** 1977 data

Source: 1984 U.S. Industrial Outlook, U.S. Department of Commerce.

\section{Architect/Engineering Firms}

Author itative, complete and current data on the number, size, geographic distribution, and economic influence of architectural and engineering firms are not easily obtained, for a variety of reasons. While the Bureau of the Census, Bureau of Industrial Economics (BIE) does gather such information on a 5-year cycle in its Census of Service Industries (the latest was in 1982), there are several major difficulties with the Census' figures:

- There is a significant time lag between the gathering and the issuing of the data. The 1982 Census results, for example, are now avaliable only in partial form. Complete reports will not be available until late 1985 or early 1986. In an industry deeply affected by market fluctuations, substantial changes can occur quickly and are not represented. Also, the building industry was severely depressed in 1982, so quantitative economic and market data cannot be considered typical.

- The census aggregates data on the basis of SIC 801 , which includes architectural, engineering and surveying service firms. These types of firms are often very different in terms of their roles and influences in the building process. Some are not involved in buildings-related activity (and instead derive income from civil and other engineering and surveying work). No such distinctions are made in the BIE data.

In 1978 the BIE divided employment on a percentage basis within the payroll portion of this sector as follows:

Architects

Engineers

Engineering technicians

Administrative and other
11 percent

23 percent

24 percent

42 percent 
- Only results from firms with payrolls are reported. Sole proprietorships and many forms of partnerships (both very common in architect) engineering firms) are not included, although the $8 \mathrm{IE}$ does occasionally prepare estimates.

The result is generally that the Census figures are low in all categories and thus may not prove to be accurate when issued. The BIE has issued preliminary 1983 estimates covering this sector that are more or less within the ranges of estimates prepared by private sources (e.g., the BIE suggests that there are approximately 63,200 individuals employed as architects; in 1982 the American Institute of Architects (AIA) received data from state architectural registration boards suggesting that there were then approximateiy 62,000 persons with current architects' licenses).

Various professional associations and publishing organizations undertake similar estimates. A professional association may wish to know how many of all possible members the association may actually represent. The drawback of these estimates is that they may not count firms that are active and influential in the building industry but that are ineligible for association membership.

\section{Architects and Architectural firms}

The AIA has two ongoing activities aimed at better understanding the dimensions of the architectural profession. Its membership is approximately 37,000 corporations.

- Individual architects. In 1982 the AIA gathered registration rosters from every state, arriving at a national total of just over 62,000 . The AIA reports significant shortcomings with this approach, not the least of which stems from the fact that several states do not keep current or complete records. Nonetheless, the AIA will gather data from these rosters annually (no other organization at present does this) beginning this year. The AIA regards an estimate of 65,000 registered architects as conservative.

- Architectural Firms. Pro-file is a proprietary directory recently acquired by the AIA that contains information on architectural firms. it is generally recognized as a reasonably authoritative source. The 
edition current iy in progress will list approximately 10,500 firms, down from the 14,860 listed in its predecessor. The decline reflects editing out of duplications and other faulty entries, as well as some business consolidation and attrition. Three factors that may be contributing to a trend of reducing or consolidating the architectural service sector are:

- the use of predesigned and pre-engineered modular housing

- the use of predesigned and pre-engineered metal commercial buildings

- the use of computer ajded design.

The AIA also includes in its count of its membership those who pay supplemental dues, an indication of the number of persons with a proprietary interest in firms. In 1984 this number was 12,800. These figures are similar to estimates from $B I E$ data which suggest that in 1982 there were 10,900 architectural firms. Knowledgeable AIA staff members generally agree that the ratio of individual AIA members to registered architects (that is, 37,000 to 65,000, or about 57\%) would also apply to the number of AIA menber firms compared with all architectural firms. This indicates a greater number of firms than suggested in BIE estimates. The AIA also confirms that by far the largest proportion of architectural firms (as much as 80 percent of the tota?) are firms with 10 or fewer employees. Further, it is reasonable to assume that the national distribution of architects follows the AIA's regional membership patterns shown in Table 3.1. As one final statistic, the AIA has a mailing list, no longer in regular use, of 13,487 firms.

The National Council of Architectural Registration Boards (NCARB), which is the association of state professional licensing agencies, reports that in midAugust 1984, there were 22,518 registered architects certified under NCARB procedures. This is to some degree a measure of the number of licensed professionals whose practices extend beyond the borders of a single state. (NCARB certification greatly simplifies the process of reciprocal licensing; a 
TABLE 3.1. AIA Membership Count as of Auqust 15, 1984

\begin{tabular}{|c|c|c|c|}
\hline Geograohic Regions & $\begin{array}{l}\text { Associafe } \\
\text { Members }\end{array}$ & $\begin{array}{l}\text { Corporate } \\
\text { Members }\end{array}$ & $\begin{array}{r}\text { Tota } \\
\text { Members } \\
\end{array}$ \\
\hline California & 1171 & 5526 & 6697 \\
\hline Central States & 539 & 2224 & 2763 \\
\hline East Central & 106 & 681 & 787 \\
\hline Florida/Carribean & 296 & 1790 & 2086 \\
\hline Gulf States & 501 & 2010 & 2511 \\
\hline I 1 ino is & 179 & 1545 & 1724 \\
\hline Michigan & 137 & 1078 & 1215 \\
\hline Middle Atlantic & 516 & 2375 & 2891 \\
\hline New England & 205 & 1948 & 2153 \\
\hline New York & 350 & 2455 & 2805 \\
\hline North Central & 244 & 1348 & 1592 \\
\hline North West & 365 & 2549 & 2914 \\
\hline Oh io & 130 & 1258 & 1388 \\
\hline Pennsylvania & 126 & 1059 & 1185 \\
\hline South At lantic & 369 & 2055 & 2424 \\
\hline Texas & 804 & 3579 & 4383 \\
\hline Western Mountain & 398 & 2150 & 2548 \\
\hline New Jersev & 129 & 942 & 1071 \\
\hline TOTAL & $\overline{6565}$ & $\overline{36572}$ & $\overline{43137}$ \\
\hline
\end{tabular}

(a) Associate members are individuals not yet licensed to practice architecture, but who are working in some capacity that will lead to eliaibility to sit for the licensing examination.

(b) Corporate members are individuals who are licensed to practice architecture.

SOURCE: Data obtained by Thomas Vonier Associates, Inc. from records at AIA headquarters.

candidate normally is required to sit for on ly one orofessional licensing examination, the successful completion of which becomes the basis for licensing in a number of states.) NCARB certification is the closest thing in the profession to a "national" license. There are, however, many architects who no longer are active in the profession but maintain, for one reason or another, NCARB certification. Although NCARB gathers no information that would support the fiqure, NCARB generally subscribes to the estimate that there are presentiy aporoximately 65,000 reaistered architects in the U.S. 


\section{Enqineers and Eng ineering Firms}

There is some assurance that reqardless of the method used to count architects, most of those included are professionals whose primary activity is in some way related to the design and management of buildings. This is not necessarily the case in the engineering disciplines, in wich a single firm may employ a variety of professionals and undertake a wide range of projects, few or none of which are related to buildings. Additional data consulted for enqineering firms were provided by the Census of Service Industries, and by some private sources.

Consulting Enqineering magazine estimates a total of 16,786 engineering firms in the U.S. The American Consulting Engineers Council (ACEC) generaliy agrees with this estimate, although the council feels it is orobably low. ACEC counted 4625 firm members in mid-1984 (ACEC has no individual members). The closest breakdown of these firms is a survey of member firms by ACEC that indicates, by percentage of the total membership, capabilities in the following areas potentially related to buildings:

Mechanical enqineering 35 percent

Electrical engineering 32 percent

Structurai engineering 46 percent.

ACEC estimates that its member firms employ about 199,000 individuals, many of whom are administrative and clerical employees. The American Society of Mechanical Engineers counted 88,710 members in mid-1984, but could offer no estimate of those active in buildings-related work.

\section{Landscape Architecture and Design}

The American Society of Landscape Architects (ASLA) estimates that there are approximately 25,000 persons in the U.S. practicing as landscape architects, approximate1y 7,000 of whom were members of ASLA in 1984. They also estimate that, in addition to many small soie proprietorships, there are approximately ?,000 firms (some of wich are also architectural firms) emp Toying landscape architects. 
Other Groups

Additional studv should be made of several groups of professionals whose influence in the building design process is substantial and increasing. These groups include, at minimum, lighting desianers and interior designers. Since these aroups are not counted as distinct occupations in Census survevs, the principal sources of information would necessarilv be private associations such as the International Association of Liqhting Desiqners (IALD), the Illuminating Engineering Societv (IES), and the American Societv of Interior Desiqners (ASIO).

There is also a growing number of "desiqn/build" firms, which, like the metal building industrv, provide both design and construction contracting services.

\section{Corporate Desian and Development}

Corporate design and develooment is considered a distinct seament of the design division because the concerns of these professionals differ from those orofessionals operating on a oroprietary basis. Data on this segment are sparse, but it can be assumed that much of the "in-house" desiqn cabability is for industrial firms whose building needs are dictated by a manufacturing process. Commercial activity is oresumed to be concentrated in the retail, restaurant, and hotel cateqories in firms that ooerate chains or franchises. Desiqn services for corporations enqaged in residential housing, manufactured housing, and manufactured metal buildinas may also be included in this seament.

\subsubsection{Construction Contracting}

The construction contracting division is seqmented along the following functional areas:

Genera 1 contractors

Excavation and foundation

Structural steel

Concrete work

Electrical
Carpentering

GTass and qlazinq

Building equipment

Printing, Daper hanging and decorating

Roofing and sheet metal 
Plumbing, heating and air cond it ioning

Plastering, drywall, accoustical and insulation
Floor laying

Terazzo, tile, marble and mosaic

Data from the U.S. Dedartment of Commerce are the most detailed for each of these segments, including primarv data on activity by building type. These data are presented in Appendix A for each segment listed above.

Figure 3.8 shows the number of firms in each industry segment, as well as the total value of industrv receipts in 1983 and value added. The value added portion of the bar chart basically represents wages and earnings for that segment. This orovides a better indicator of the value of labor, while tota? receipts provide an indication of the relative budget responsibility for each of the contractor types. Representation of the number of firms in each cateqory provides an indication of how widely dispersed firms are, and allows the reader to interoret the relative size of firms using the cost data.

\subsubsection{Materials and Components Manufacturing and Supoly}

The manufacturina division is a primary technology transfer agent for the building industry as well as a primary source of innovation. It is also one of the most difficult segments to characterize, especially in quantitative terms, because of its large size and diversity. Detailed information on the following seqments according to SIC code, is presented in ADpendix B:

Fabricated structural metal

Prefabricated metal buildings

Steel metal work

Flat qlass

Hydrau 1 ic cement

Concrete block and brick

Current carrving wiring divices

Non-current carrying divices

Lighting fixtures

Structural wood

Particle board
Ready mixed concrete

Concrete products

Brick and structural clay tile

vitreous plumbing fixtures

Meta 1 olumbing fixtures

Plumbing fixtures and brass goods

Sawmills and planing mills

Hardwood dimension and flowing

Softwood veneer and plywood

Millwork 
General Contractors Single Family Houses General Contractors Multi-Family Residentia! Operative Builders General Contractors Nonresidential Other than Industrial

Plumbing. Heating and Air Conditioning

Electrical

Plastering, Drywall, Accoustical and Insulation Roofing and Sheet Metal Work

Concrete Work

Excavating and Foundation Work

Carpentering

Painting, Paper Hanging and Decorating

Installation or Erection of Building Equipment Masonry, Stone Setting and Other Stonework

Structural Steel Erection

Glass and Glazing Work

Floor Laying and Other Floorwork

Terrazzo, Tile, Marble, and Mosiac Work

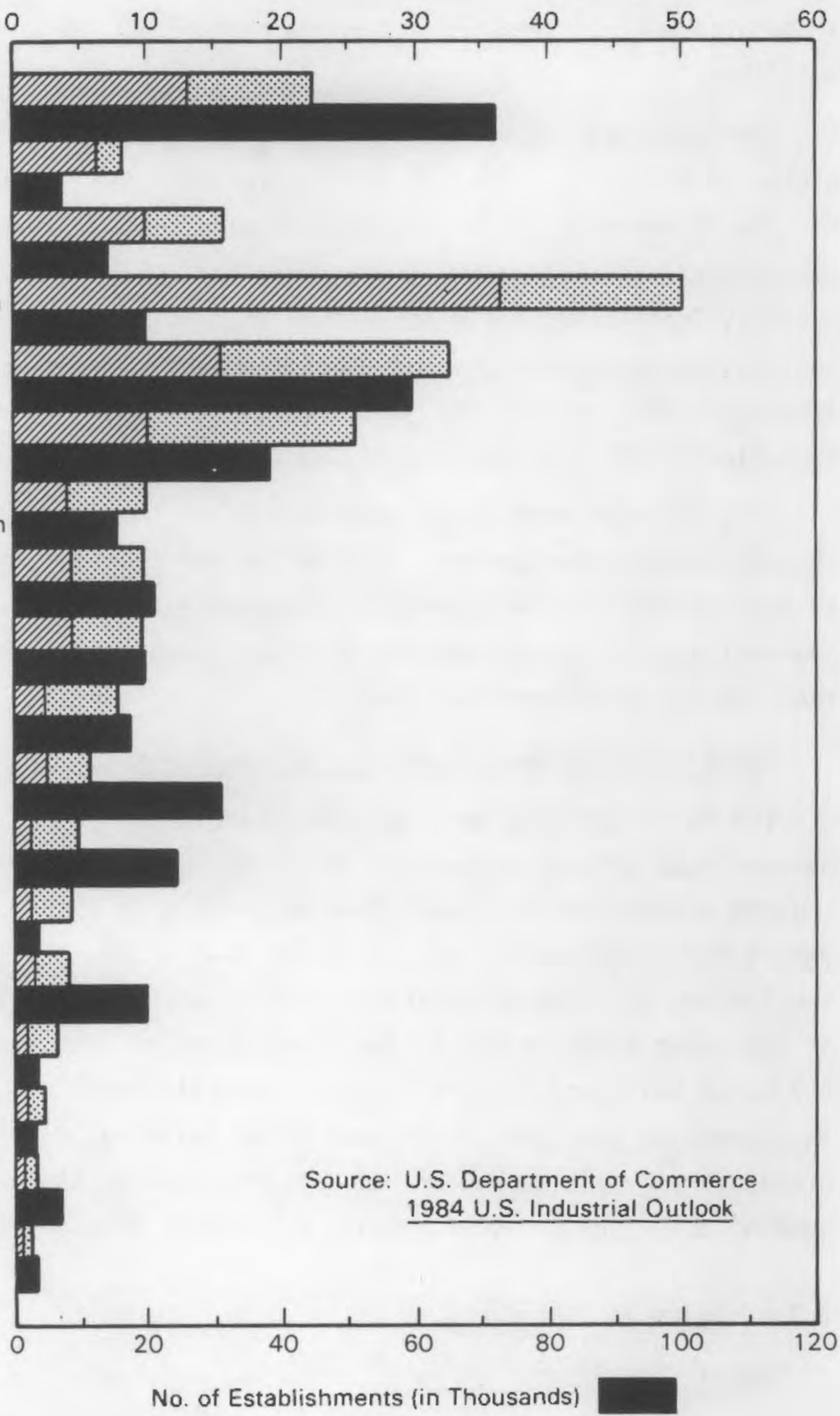

FIGURE 3.8. Summary of 1983 Construction Contracting Division by Industry Segment 
Figure 3.9 shows the relative size of each industry segment in terms of 1982 dollar volume (in 1977 dollars). This describes the relative imoortance of each segment in terms of its product contribution to the composition of buildings.

Manufacturing and supply activities are primary sources of technical information on buildings. Product literature describes not only what is available for use in constructing buildings, but also the techniques for installation, the soecifications, and the limitations for application. The supply function not on iv facilitates the distribution of product literature, but also provides the technical support for product use through knowledgeable distributors, sales personnel, and regional and local representatives. These people consult and communicate with both the specifving community and the construction sectors.

This division provides a major source of innovation for the industry through product development. The design and construction sectors are limited by the availability of materials and components. In a sense, design professionals simply select products and components for a given building, and then soecify their confiquration.

Metal Building Manufacturers, Designers and Builders

The Metal Building Manufacturers Association (MBMA) estimates that its members manufactured 51 percent of al1 nonresidential buildings of less than 150,000 square feet in floor area constructed in 1983. The MBMA has 34 manufacturing members, who account for most of the activity in this sector. The Svstems Builders Association (SBA) is another organization which consists of just over 8,000 contractor/builders, many of whom also offer design services for metal buildings. These figures generally agree with figures obtained from the Bureau of the Census. Because these buildings rarely involve design professionals, but represent a substantial market and are actually designed, some of this industry's activities could also be classified as desian services.

\subsubsection{Codes and Standards}

\section{Model Code Orqanizations}

Three national organizations maintain model building codes for states and municipalities to adopt as legal guidelines for construction. Each 
Sawmill \& Planning Milis

Fabricated Structural Metal Ready Mixed Concrete

Sheet Metal Work

Millwork

Softwood Veneer \& Plywood Concrete Products N.E.C.

Hydraulic Cement

Prefabricated Metal Buildings

Plumb. Fixture Fittings \& Brass Goods Concrete Block \& Brick Flat Glass

Hardwood Dimension \& Flooring Brick \& Structural Clay Tile Structural Wood Members Metal Plumbing Fixtures Vitreous Plumbing Fixtures Particleboard

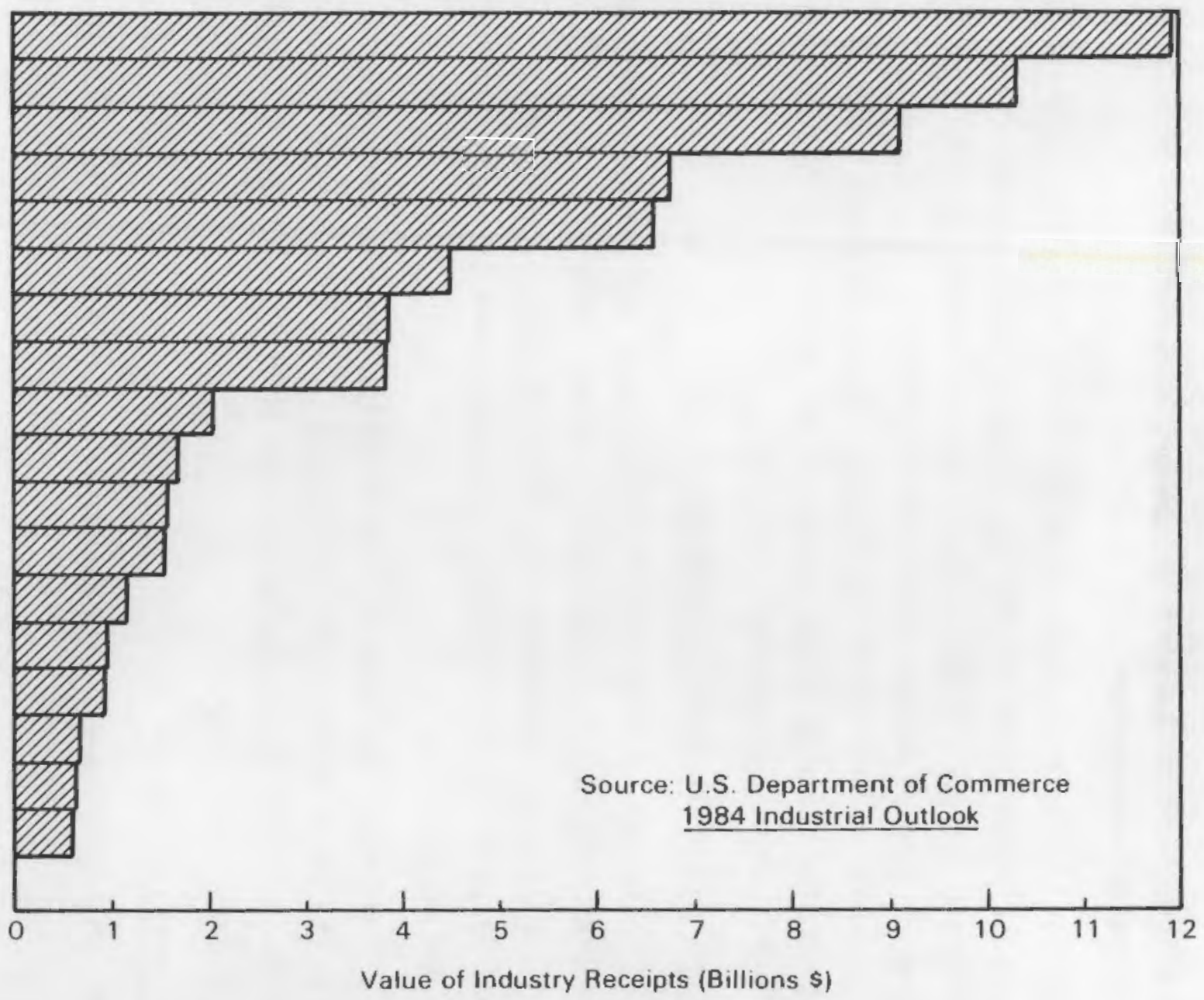

FIGURE 3.9. Materials and Components Manufacturing, Distribution of 1984 Receipts by Industry Segment 
organization provides minimum standards on design, construction, and materials to insure public safety and welfare.

The International Conference of Building Officials maintains the Uniform Building Code, which predominates in the Western U.S. Building Officials and Code Administrators (BOCA) International, Inc. maintains The BOCA Basic Building Code, which is used orimarily in the Eastern U.S. The Southern Building Code International maintains the Standard Building Code, which is prevalent in the south. Each of these orqanizations has its own procedures for modifying the model codes it maintains.

\section{Building Codes Coordinating Organizations}

The National Conference of States on Building Codes and Standards is the premier organization promoting building code uniformity coordination among states and municipalities. Its members are state and local government representatives, local building officials, architects, engineers, contractors, manufacturers, and others.

The Council of American Building Officials (CABO) serves as an umbrella organization for the three model code organizations. It acts as a clearinghouse for code changes, and it represents a membership of about 8,000 cities, counties, and states.

Standards Orqanizations

A number of organizations maintain standards that affect the buildings industry.

American National Standards Institute

Underwriters' Laboratories

American Society of Heating, Refrigeration and Air Conditioning Engineers

American Institute of Architects

National Fire Protection Association

Illumination Engineering Society.

\subsubsection{Education}

Architectural Schools and Educators

There are 102 degree-granting programs in architecture in the U.S. and Canada, embloying approximately 2,400 full time faculty members and another 
1,000 part time or adjunct faculty. The Association of Collegiate Schools of Architecture (ACSA) estimates that approximately 33,000 students are in architectural schools in a given year. Approximately 11,000 persons took the NCARB professional licensing examination in 1984 (about 40 percent of whom are expected to have passed). Although these individuals are generally not directly out of school (because they must serve an internship prior to qualifying for the examination), this number is useful as a general indicator of the numbers entering the professional ranks annually.

\section{Other Education}

Engineering degrees are offered at schools throughout the U.S. The curricula offered are fairly standard and usually contain considerable emphas is on enerqy. However, there are other educational opportunities. Some trade unions, notably the electrical works and plumbers' unions, require not only an apprenticeshio, but also the successful completion of a multi-year night school curriculum. 
]

[

.

(

(1)

]

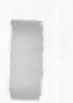

]

(1)

Q

,

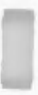

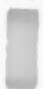

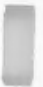

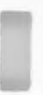

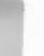




\subsection{TECHNOLOGY TRANSFER MECHANISMS AND THEIR ENVIRONMENT}

\subsection{INTRODUCTION}

The previous chapters established a framework for understanding the complex decision processes of the buildings industry and an overview of the texture of the industry. With the aid of this model, information on enerqy conservation can be presented to the appropriate decision makers. However, vehicles or transfer mechanisms are needed for oresenting this information. Examples of these mechanisms are reports, brochures, trade publications, and manufacturer representatives. Selection of the most effective and efficient transfer mechanisms requires an understanding of the pathways by which information can reach the buildings industry and an understanding of the environment in which the transfer of information occurs.

Successful transfer of R\&D information from laboratories to industry decision makers involves the activities of many broker organizations as well as interactions among building industry decision participants (see Figure 4.1).

Transfer mechanisms must be focused on those who actually make the important decisions. This selection of targets is assisted by the information about decision makers and industry segmentation, presented in Chapters 2 and 3 , respectively.

In this chapter the importance of information pathways is examined by exploring the complex interactions involved in technology diffusion. Options for saving energy that are technically proven and that are aesthetically pleasing and that are projected to become available at lower cost can take a very long time to diffuse into the market. Shama (1983) indicates that the process can only be understood by a combined engineerina, economic and behavioral perspective. The engineering and economic attractiveness of an energy savina concept has to be favorable, but that is not enough. Shama indicates that the use of energy conservation concepts may be speeded up by applying the concepts of technology diffusion. The concepts of technology diffusion provide illumination of the reason that technology can take so long to find application. The technology diffusion concepts are explored and are applied to the RU process in the following paragraphs. 
The information pathways and the environment in which they operate appear to be even more important than the content or form of communication in the buildings industry. In this chapter we first examine the complex interactions in the decision environment which make the pathway so important. Subsequently, we briefly examine the broad spectrum of transfer mechanisms (pathways, content, and form) available for use in the building system environment.

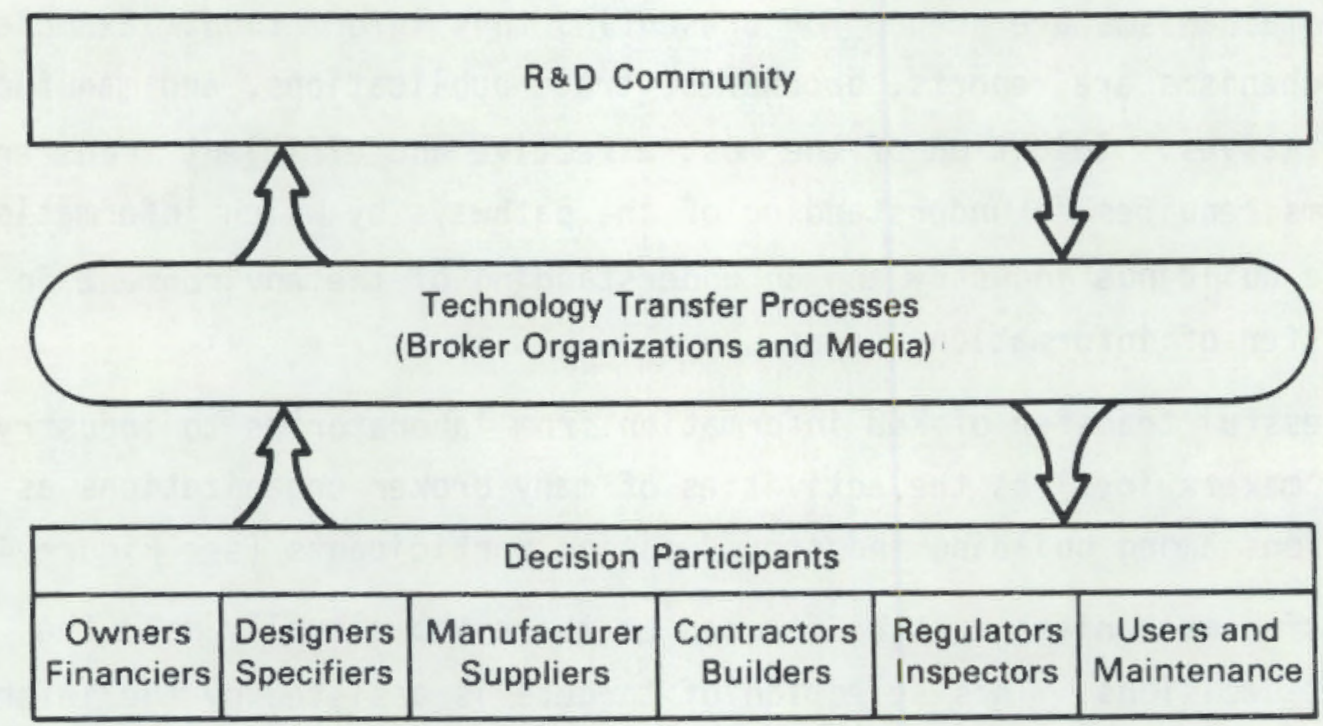

\section{FIGURE 4.1. The Research Utilization Process}

\subsection{THE DECISION ENVIRONMENT}

\subsubsection{The Individual Decision Process}

All significant decisions involve individual actions, but the adoption of a new concept may involve a number of participants. Each of these participants move through a series of staqes (Rogers 1962):

- Awareness

- Interest

- Evaluation

- Trial

- Adoption.

The most effective way of communicating information about a new technology changes as decision makers pass through these various stages. During the awareness staqe, impersonal forms of communication, such as journals and 
books, appear to be the most effective. As decision makers oass to the evaluation stage, more personal communications, such as peer contacts, become more effective. In other words, it becomes a people to peoole process! In addition, decision makers tend to place more confidence in information that comes from more than one independent source.

\subsubsection{Cateqories of Decision Makers}

Rogers (1962) provides a categorization scheme that classifies decision makers as innovators, early adopters, early majority, late majority, and lagqards (Figure 4.2). Innovators and early adopters are important participants in technology diffusion. These two groups are the first to try a technology, and their use of technology usually results in acceotance by the subsequent groups of adopters.

The primary differences between innovators and early adopters are the following: 1) innovators accept more immediate risk for ootential longer term benefits; and 2) innovators stress both monetary and non-monetary benefits, while early adopters acceot or reject a new technology on the bas is of normal market factors. Our investigation indicates that these two groups are

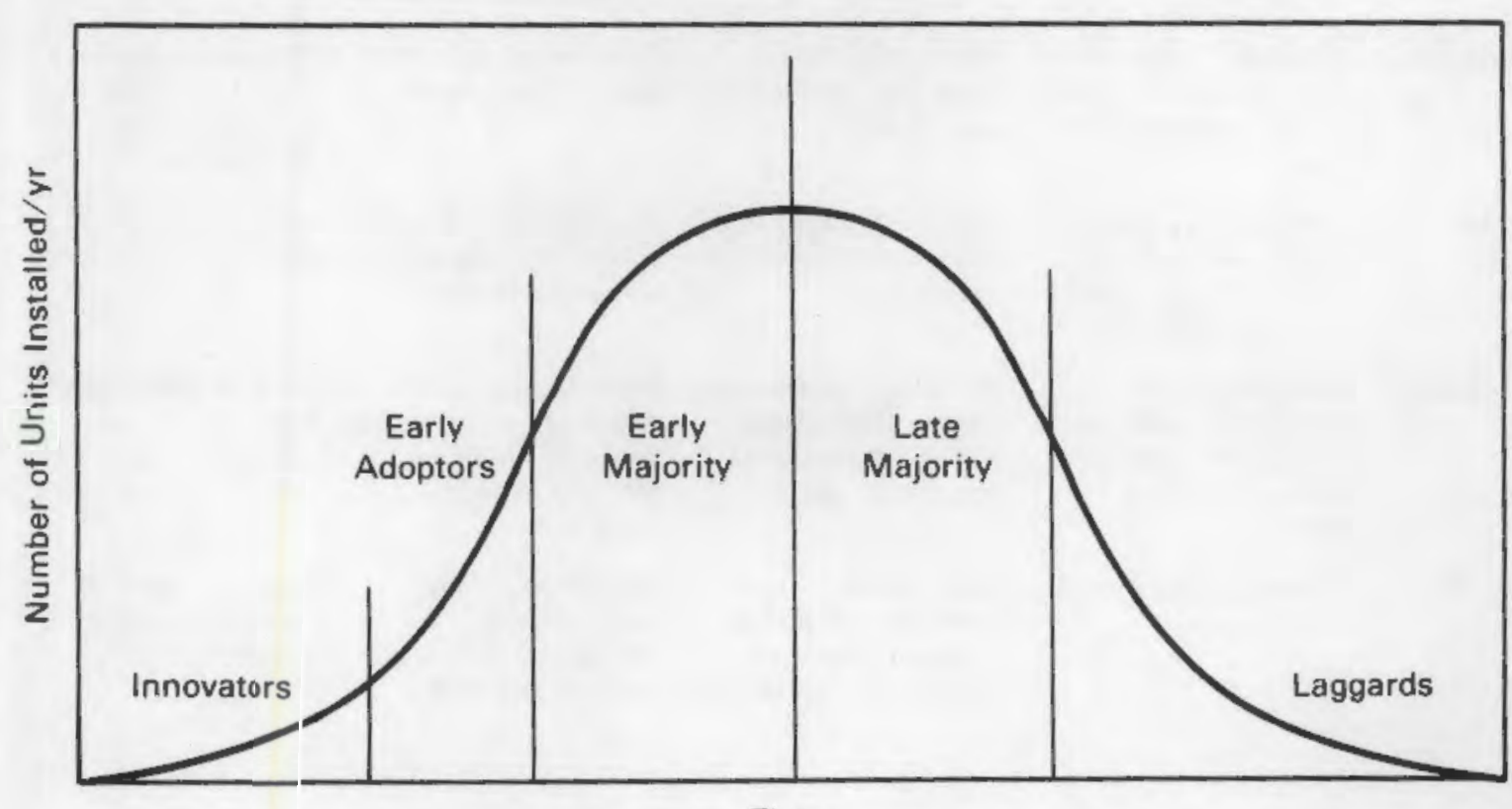

Time

FIGURE 4.2. Characteristic Groups of Techno logy Adopters 
as important in the building industry as they are in other industries we have examined. Innovators are willing to take much areater risks now for the potential of a future payoff. Early adopters, on the other hand, expect to see an inmediate return for participation.

Since these two groups appear to operate from different motivations, it is logical to assume that they may require different transfer mechanisms and even different channels for those mechanisms. For example, innovators tend to rely more on imoersonal communications (publications, for instance) than subsequent categories of adopters, who rely more on personal communications with trusted adopter veers. Innovators also use a greater variety of information sources than do later adopters, who are less willing to take risks (see Table 4.1).

TABLE 4.1. Characteristics of the Adopter Groups (from Rogers 1962, p. 185)

\begin{tabular}{|c|c|}
\hline $\begin{array}{l}\text { Adopter } \\
\text { Category }\end{array}$ & $\begin{array}{l}\text { Salient } \\
\text { Values }\end{array}$ \\
\hline Innovators & $\begin{array}{l}\text { "Venturesome", will- } \\
\text { ing to accept risks }\end{array}$ \\
\hline Early adopters & $\begin{array}{l}\text { "Respect", regarded } \\
\text { by many others in the } \\
\text { social system as a role- } \\
\text { model }\end{array}$ \\
\hline Early majority & $\begin{array}{l}\text { "Deliberate", willing } \\
\text { to consider innova- } \\
\text { tions only after peers } \\
\text { have adopted }\end{array}$ \\
\hline Late majority & $\begin{array}{l}\text { "Skeptical", over- } \\
\text { whelming pressure } \\
\text { from peers needed } \\
\text { before adoption } \\
\text { occurs }\end{array}$ \\
\hline Laggards & $\begin{array}{l}\text { "Tradition", oriented } \\
\text { to the past }\end{array}$ \\
\hline
\end{tabular}

\begin{tabular}{l}
\multicolumn{1}{c}{$\begin{array}{c}\text { Personal } \\
\text { Characteristics }\end{array}$} \\
\hline Youngest age; highest \\
social status; largest \\
and most specialized \\
operations; wealthy
\end{tabular}

High social status; large and specialized operations

Above average-social status; average-sized operation

Below average social status; smail opera. tion; little specialization; small income

Littie specialization; lowest social status; smallest operation: lowest income; oldest

\section{Communication Behavior}

Closest contact with scientific information sources; interaction with other innovators. relatively greatest use of impersonal sources

Greatest contact with local change agents

Considerable contact with change agents and early adopters

Secure ideas from peers who are mainly late majority or early majority; less use mass media

Neighbors, friends, and relatives with similar values are main information source
Social

Relationships

Some opinion leadership, very cosmopolite

Greatest opinion leadership of any category in most social systems; very localite

Some opinion leadership

Little opinion leadership

Very little opinion leadership: semiisolates 


\subsubsection{Importance of Interactions Among Dec is ion Participants}

Strong interactions among the groups making the key decisions in the building industry influence each decision. Broker organizations and R\&D information sources are also important in influencing those decisions as the groups of participants move through the stages of innovation.

Large scale apolication of energy saving technology will not occur until there are owners that desire the technology, financiers that will supply the money, architects/engineers that will risk their professional reputations, manufacturers that will invest in mass production facilities and in nationwide distribution, contractors that will warranty their installation, compliance and inspection personnel that understand and approve the new approach, building users that want the technology, and maintenance men that can keep the equipment working. However, the owners will not approve the technology until they are aware that occupants desire the concept and that more than one manufacturer can supply it.

The decision participants exercise veto powers over the selection of energy conservation technology. The sophisticated architect does not say, "I won't." What the architect does say is, "If you really want me to, I can design it for you, but it will be a lot more expensive." The manufacturer says, "I can make it for you, but it will cost." The distributor says, "I can get it for you, but it will take an extra 3 months." The contractor says, "If vou insist, I can put it in, but I hear that they don't hold up, so I cannot give you any warranty." The individual with final approval does listen to his peers and to other decision participants, qiving them effective de facto veto power, even though they may not actually sign concurrences. Trusted sources such as peers and industry participants may be more important in the decision process than the exact form or content of technology transfer communications.

\subsubsection{Technology Diffusion in the Buildings Industry}

The technology diffusion process frequently takes longer in the buildings industry than in other "fast moving" industries. Speeding up this process 
requires an understanding of the steps involved in the adoption of a new technology.

Many new technologies appear to have great promise at first as a few enthusiastic innovators express optimism. But the technology frequentiy encounters more difficulty than expected and quantity buyers may stay away in large numbers. This is a feedback (market signal) to industry or to R\&D organizations that the technology is not "ready" (see Figure 4.3). In the electronics industry it has in some instances taken 15 to 20 years for technology to penetrate a market. It is quite normal in this high-technology industry for new technology to go through one or more false starts before it is finally accepted (see Fiqure 4.4, Murray 1981).

The electronics industry might be expected to accept technology more quickly than the buildings industry because 1) one person can frequently make the decision to purchase; and 2) the industry is more compact, and fewer institutions are involved in brokering and regulating the use of new technology.

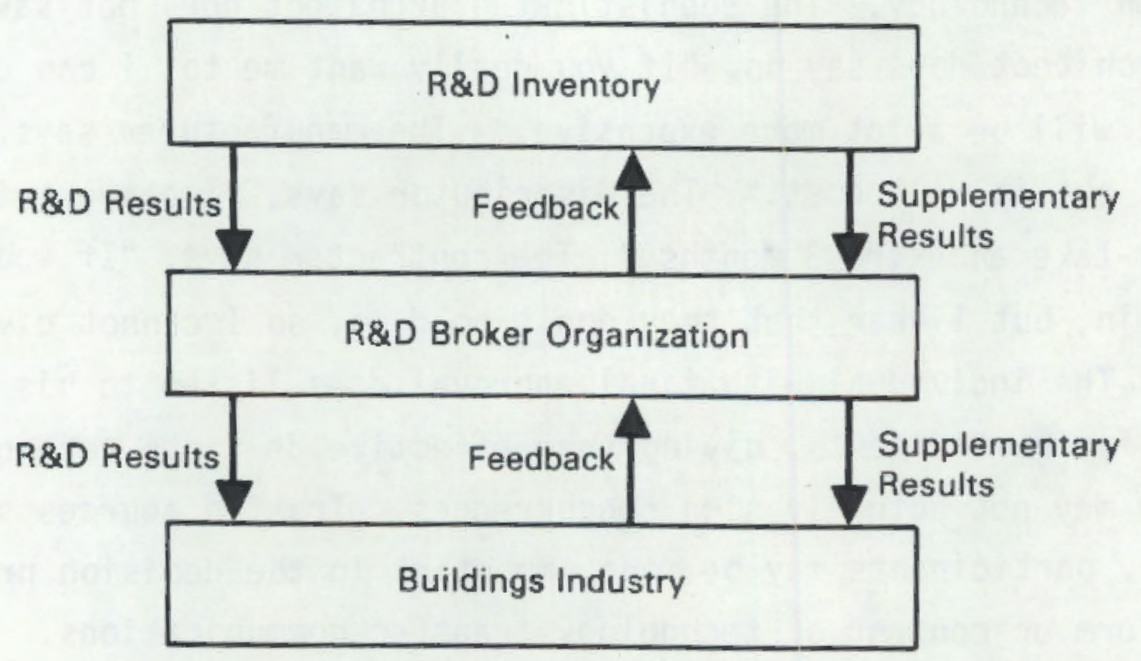

FIGURE 4.3. Transfer Involving Recycle 


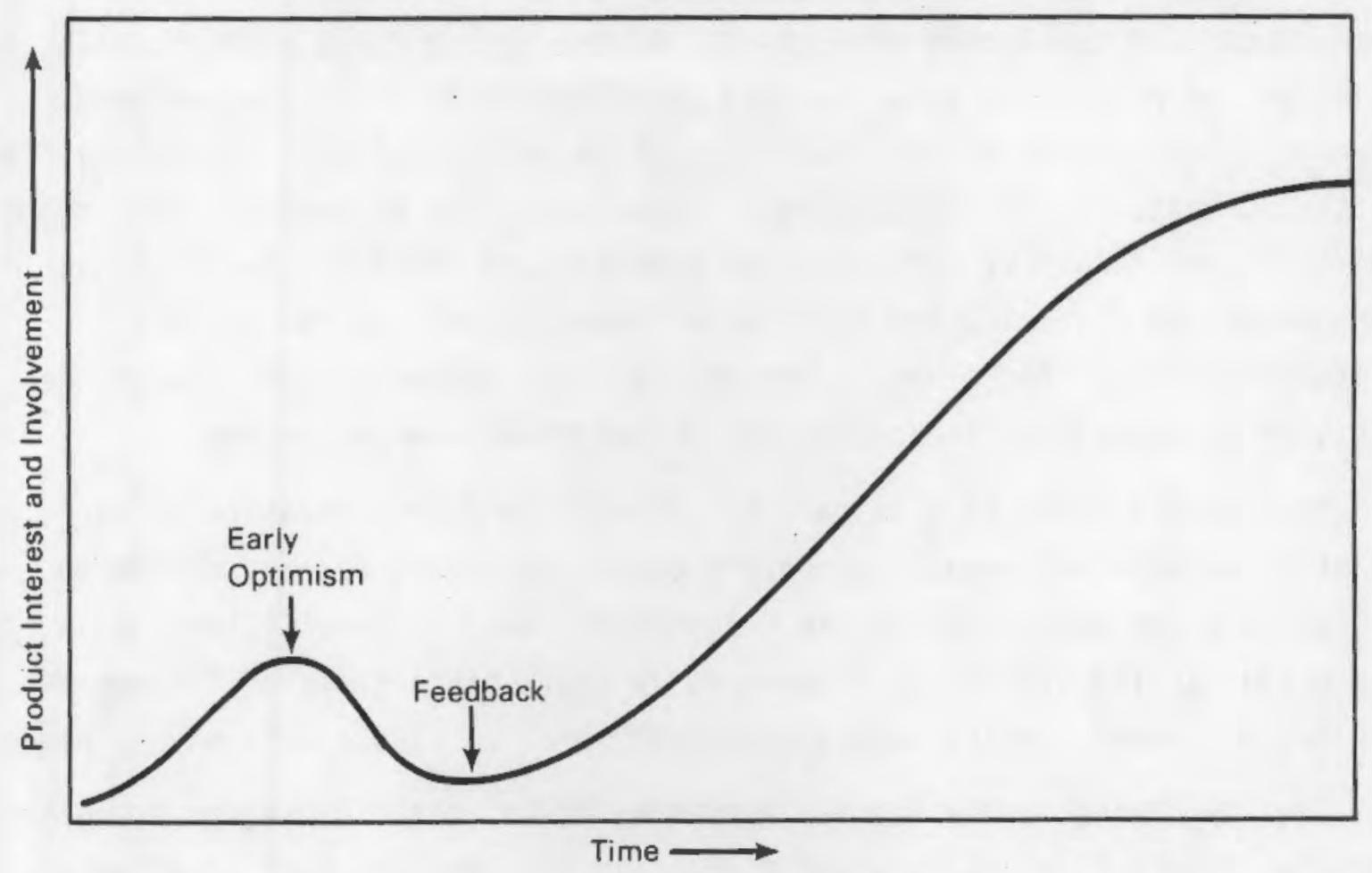

FIGURE 4.4. Typical Swings in Technoloqy Interest Level

\subsubsection{Why Innovators are Crucial to $\mathrm{RU}$ in Buildings}

New technology must be used by innovators in large enough volume to reduce the perceived costs and risks, and to demonstrate the benefits of the technology to the early adopters. In other words, new products and technologies must compete with established technologies, which have already progressed along a "learning curve."

The technology diffusion efforts of interest to this study must go through the innovator phase of market acceptance to achieve perceived costs/benefits sufficient for acceptance by each of the eariv adopter participants. Technology can not skip the innovators and go directly to early adopters unless there are no cost penalties (including risks), and the performance of the new technology is significantly better than that of the existing products. These situations are rare, and in any case, they require little or no assistance from technology transfer efforts to find their way into the marketplace. 
Learning curves show the relationship between the unit cost of a good or a technology, and cumulative production. As the market for a product grows, the unit cost of production tends to fall as economies of scale are achieved. However, these curves neglect the transaction and installation costs involved in the purchase of a new technology. These costs can be extremely important in the buildings industry. Distribution channels are difficult to establish because of the diversity and geographic dispersion of the participants. Installation costs for a new technology can be tremendous, and maintenance cDsts of an unfamiliar technology can outweigh any energy savings.

Many technologies fail to make the transition from innovators to early adooters because not enough innovators participate in the early market to reduce both the manufacturing and transaction costs to competitive levels. In the buildings industry, this is especially true, since teams of innovative owners, designers, manufacturers who would agree to participate may be needed.

Ideally, large initial costs, including risks, might be shared among the decision makers (innovators), who might gain the benefits over a period of time. This is unlikely to occur because of the diffuse nature of the buildings industry. A disproportionate share of the costs would probably be borne by a few of the decision makers (perhaps the owner or the speculator).

When a sufficient number of innovators cannot be located, it may be necessary to find ways to motivate some early adopters to act like innovators.

A major factor affecting the difficulty to be encountered by a new techno 1ogy is the number of decision makers perceiving large risks. The technology which can be manufactured on existing machinery, distributed through normal supply channels, and finally "transparent" to the user (i.e., does not appear different or require life style changes) will be accepted much more readily than technology that requires major changes in one or more of these factors. A $10 \%$ improvement may be adequate (when it is available from fullv trusted sources) for the lower risk situation, whereas a $100 \%$ improvement may not be enough to overcome the requirements for new production machinery, new distribution and new appearance, and life style changes. 


\subsubsection{Decision Environment for Innovation Participants}

There are important differences in the decision environment for the groups of participants identified in chapter 3 during the innovator phase of a product's life. The following oaragraphs review the decision environment of the various aroups participating in the acceptance or rejection of new building technology.

\section{Building Owners and Financiers}

The complexity of the technologv transfer process in the buildings industrv causes most of the changes that take place to come very slowly. For this reasin, other market areas are likelv to appeal more to the innovative owner/financier. Venture capitalists, however, mav be able to give some indication of what motivates owners/financiers in the building industrv. Cambridge Research \& Development Group provides a brief summary of what they look for in new technologv:

1. Does someone reallv need the product? Not might like or might buv, but reallv need it?

2. Does a market know that it needs a oroduct? Even though it may be aood for a company, if it has to spend monev to convince peoole they need the product, look for a better idea.

3 . Does the market oerceive an inmediate need for the product? Not six months or a year from now, but an inmediate need.

4. Does the consumer who perceives the need also control the purchase decision? Can he or she come up with the money?

5. Can it be manufactured for $5 \%$ or $10 \%$ of the selling price? If a oroduct is really innovative, the company should be able to make a lot of money marketing it. Forget the whole matter if it doesn't promise to earn at least 15 after-tax profit on each $\$ 1$ of sales.

6. Can patents be protected? Concentrate on a field where oatents are respected.

7. Is there a 0001 of buvers for the product at the price that produces profit today? The ability to sell a product eventually for $\$ 500$ won't helo get the companv off the around with a $\$ 1,000$ product un less there are enough buvers right now at $\$ 1,000$ to finance future growth. 
8. Will product success strain the company's financial, manufacturing, or marketing resources? Many companies evolve elaborate contingency plans in case of failure but are unprepared for success.

9. Is the environment noncompetitive? If yes, the product's chances for success are improved, especially if the company gets an edge on the market before similar products arrive.

Financially affluent owners who intend to occupv the building themselves may see the new technology as providing unique non-monetary benefits such as improving qualitv of life and productivity and thus, mav provide an alternative to meeting the financially oriented needs of the investor.

Targeting innovators in the owner/financier qroup is a challenge because those who can afford the higher costs of the initial investment in a new conced probab?y can afford subsequent fuel costs even if they increase drasticallv. From our discussions with industry, we have come to believe that investor owners are less Tikely to be a good source group for the needed innovators than are affluent resident owners. This owner/occupier market seqment may sometimes be more interested in the aesthetic and functiona? potential of energy-saving concepts than in the actual amount of energy saver. For examole, Dassive solar concepts can, when oroverly implemented, add charm. The ambience of an atrium can be enhanced by the oroper use of natural light. Selling huilding owners and financiers on saving energy may be even easier when the collateral benefits, such as enhanced appearance and ambience, are stressed.

Designers and Specifiers

There are powerful forces which may keep architects from actually pushing new building technology. Established architects have reputations to guard. The better established they are, the busier they are and the more substantial are their investments in repeating former success patterns. These patterns may have been very innovative in the past. In addition, they may simply be too busy with more urqent matters. A new architect, on the other hand, has no reputation to uphold, and may, in fact, ga in highly valuable recognition from being "different." 
Sweet's file is highly regarded by designers and specifiers as a source of information on building components and construction materials. Unfortunately, Sweets' file is primarily filled with information on established products. Our investigation reveals that product brochures supplied by sales personnel are also a highly regarded source of information to designers and specifiers. New technology is almost by definition that technology which has not been put into products and quality brochures by manufacturers and suppliers. Also, publications that emphasize new technologies tend to be viewed as less credible. Thus, Sweet's may not provide much information on "innovations" or R\&D results. On the other hand, if the information can be included in the regular sections of Sweet's, it may be highly regarded and trusted.

The Federal R\&D reports (including those residing in the National Technical Information Service system) are not frequently accessed by this group.

Manufacturers and Suppliers

Manufacturers and suppliers are vigorousiy pursuing new products and innovations that $c$ an be built on existing machinery, for less money, handled by existina distribution channeis, and that offer significant benefits to the consumer without requiring life style changes. This group frequently reviews a new technologv using the nine questions listed earlier in the Owner/Financier section.

Several studies have reported that smaller firms tend to be more innovative than larger firms. Many larae firms operated by professional managers are not perceived as being innovative. The half-iffe of the general manager tends to be rather short--perhaps a couple of years. If the manager is good, he or she will be promoted; if not, a replacement will be found on the bas is of what happens this vear. It might be possible to malign large firms for the ir lack of an innovative climate. Actually, many large firms, like General Electric, have so many low risk investment opoortunities that they cannot beg in to afford to follow up all of the more innovative ideas that come to their attention.

It is more important to go with a company that understands the market you wish to oenetrate than it is to emphasize technical capability alone. It may be easier to acquire technical talent from government laboratories, for 
instance, than to acquire knowledge of customer mores and understanding of their needs.

Manufacturers/suppliers may participate in the innovator phase to enhance their image as leaders in bringing out the newest technology as well as in being in on the "qround floor" in a growth industry.

Contractors and Builders

Contractors and builders have a very larqe potential for vetoing new technologv. They usually are not keen on being innovators and frequently they will trv to substitute standard equipment. Frequently they succeed. Technology transfer efforts should plan to neutralize this potential veto by:

- Spending R\&D money on reliability of the concept, not just on the concept itself. When the electrical contractor gets a call in the middle of the night from an irate customer on a fixed income, vou can be certain that he or she will fight anv further installation of the high technology thermostat which caused the call.

- Make certain that earlv test installations are well maintained and firmly decommissioned. R\&D reports with their technical honesty tend to frighten the contractor/builder by discussing all the problems encountered with early experimental units.

Federal programs to train installers and to pav for the maintenance and inspection of early installation appear to be very important. If federal officials have personallv requested industrv participation in early installations, it is very important for the equipment to perform flawlessly.

Regu lators and Inspectors

Regulators and inspectors have little to gain and much to lose by allowing new technology to be tried by innovators. Usually, the best way to proceed is to make them eariv particioants in the planning of the project. They are rarely hostile to new technology and can help in getting variances through the system. They are more likelv to do this if they are brought on board early.

These early contacts should be made by the architect or builder, who would normally be calling in the inspector to approve the work. The personal touch

\subsection{2}


is 11 important here. Model codes and actual code changes are useful but the problem is that the period when they are most needed is also the period in which the technology is so new that the codes are not yet available.

\section{Building Users and Maintenance Personne?}

Building users and maintenance personnel can be very creative in disabling enerqy saving apparatus. New equipment that requires extensive maintenance probably will not qet much attention in many installations. It is preferable to desian maintenance out of the product. The alternative is that reports will soon filter back from the early installations such as "those new thermostats don't work."

Early installations are likely to receive uniformly good reports at first, but the truth begins to come out as first enthusiasm fades. Poor design/ installation causes negative feedback, which will be carried back to the other decision particioants.

Users who are not owners have on ly indirect input into the decision process. Investor owners will sometimes give serious consideration to energy saving concepts requested by very reliable tenants siqning long-term leases.

Damage prevention and control is the best strategy for building users and maintenance groups.

\subsubsection{Sumary of Strategies tp Deal With the Decision Environment}

Keys to transferring technology in the buildings sector are summarized below.

- Parallel "media blitzes" in widely read journals can produce the first stage of the acceptance process (awareness) but cannot replace the more personal influences, such as favorable impressions provided by associates in the building trades during subsequent stages of the acceptance process.

- Ideally a team of innovators from various decision qroups needs to be involved in getting a new concept into a butiding project, but where innovators cannot be located in sufficient quantity, it may be necessary to convert some "early adppters" into "innovators." 
- Technology transfer strategy should provide for facilitating and speeding up communication between R\&D and industry.

- Ideally, transfer efforts should target innovators rather than early adooters unless risks to all of the key decision participants are minima 1 .

- Transfer mechanisms should be designed to either lower the perceived risk and costs or increase the verceived benefits to innovators.

- One possible way to reduce the risks for each participant is to promote the sharing of risks by the various qroups of decision makers through the use of shared savings contracts.

- The innovators in the groups of decision oarticipants have motivations different from early adopters, early maiority, late majority, and laggards (reputation drives some, while being first drives other innovators).

- Different mechanisms may be required for the different groups of participants. Young architects, for instance, might value high visibility awards such as having designed the "energy saving house of the vear."

- Trusted Dathways for technoloav information (different for the various decision participants! appear to be more important than the form or content of the cormunication.

- Damage prevention and control (oreventing negative occurrences and impressions) is just as important as getting "a good press" for new technology.

\subsection{MEDIA AND PATHWAY MECHANISMS}

There is no Derfect media or transfer mechanism. Instead, there are niches for a variety of mechanisms, with some working better than others in specific situations. The purpose of this section is to provide a method of examining the effectiveness of various mechanisms for transferring research results to the buildings industry.

Common industry practice is to differentiate between institutional advertising, product advertising and specific promotions. This parallels the need, 
as discussed in the orevious section, for first creating awareness and then adoption.

Also exoressed in the previous section is the need to proaress from impersonal to more personal contacts. The adoption of new technology involves a dynamic interaction which has many parallels to selling/buying in industry. The following paragraphs examine the various media mechanisms.

\subsubsection{Measures of Effectiveness of Transfer Mechanisms}

The effectiveness of transfer mechanisms can be characterized according to several descriptors. The descriptors should allow for the measure of the effectiveness of the transfer mechanisms in accomplishing specific functions. The following descriptors have been selected for this analys is:

Formatting: The format in which information can be used is usually far different from the way in which data are collected and reported in a technical report or journal article. This was highilighted in the 1984 Roundtable on Technology Transfer and Research Utilization (Achenback and Seaton 1985).

Validation: Much of the flood of information available to decision makers is discounted because they do not have the time, facilities, or inclination to verify its readiness for comercial use. For example, government reports are widelv regarded as "theoretical," i.e., not valid for use outside the Taboratory.

Accessibilitv: The information readily available at the crucial moment of decision is all that is actually used.

Risk Reduction: Some mechanisms have direct impact on risk and allow potential users to validate the technology without considerable expense. Involvement: The personal touch can increase the effectiveness of the other functions discussed above.

Feedback: An awareness of industry reactions is vital to the effective utilization of R\&D results.

A preliminary discussion of available transfer mechanisms follows using the above descriptors. 


\section{3.?. Broker Orqanization Effectiveness}

Broker organizations transform and validate technical develooments into useful formats and communicate them to industry. There are many broker orqanizations in the U.S. The effectiveness of technology transfer by these organizations varies widely. This tooic is being explored by 0ak Ridae National Laboratory in considerable detail. A preliminary discussion follows.

Formattina: Broker organizations vary widely in their capability in this parameter. Those made up of members of the trade/profession they represent may do very well. Those made up of lobbyists (frequently not technically trained) may be less effective.

Validation: Broker organizations can be vital because they publish guides and participate in standards setting. These activities require considerable time to accomplish through cormittee. This time factor may cause them to be more effective in communicating with early adopters than with innovators.

Accessibility: Guides widely distributed to the membership can be very valuable in influencing decisions.

Risk Reduction: Guides containing "acceoted oractice" provide considerable leqal protection to the practicing professional and tradesman. However, since quides laq new technology they may actually increase the liability of the decision maker who first employs new technology. Involvement: The degree of involvement depends on the type of broker organization and its context of interests and its geographical distance from the decision maker. Personal contact and interest is even more important than geoaraphical oroximity.

Feedback: Broker orqanizations can orovide feetback, but the feedback gets processed and modified on its way. The bluntness of actual industry reactions can be softened by broker organizations and industry needs mav be oresented through a filter of orqanizationa? agenda and neers that can color the feedback messages. Perhaps more serious is the time factor: while feedback may not occur fast enough to assist in the innovator phase, it may be fast enough to expedite the early adopter and subsequent phases. 
Broker organizations are very active and may be effective in promoting the building industrv. Their effectiveness during the innovator phase (the introduction of new technologv) is open to question. Broker organizations are obviously quite effective in making the full transition to widesoread market acceptance (by providing ASHRAE guides, for instance). More work needs to be done to determine how they can be more effective in the beginning of the transfer process.

\subsubsection{Mechanisms Available for Technology Transfer}

A wide variety of mechanisms can be used in technology transfer. The effectiveness of these mechanisms depends on the situation. The effectiveness of each mechanism can only be measured for a specific group of decision makers for a specific situation. However, general trends in effectiveness of generic transfer mechanisms can be reviewed. In Table 4.2 generic mechanisms are reviewed for their effectiveness in formatting, validating, making information accessible, reducing risk, and providing personal involvement and feedback. Conclusions from this generic review should be made with caution. However, it can be said that many mechanisms and broker organizations are needed.

The generic mechanisms listed above include specific mechanisms:

- Involvement of the building industry in R\&D

- Planning

- Monitoring

- Evaluation

- Personnel exchanges

- R\&D laboratories and manufacturers

- R\&D laboratories and designers

- Interagency R\&D teams

- Limited R\&D comoany partnerships to handle the initial risk of new technology introduction

- Institutional mandates and actions

- Federal energy performance standards

- State and local performance standards 
TABLE 4.2. A Preliminary Review of Generic Transfer Mechanism Effectiveness

Risk

\begin{tabular}{cccccc} 
Formatting & Validation & Accessibility & Reduction & Involvenent & Feedback \\
\hline Low & Low & Low & Low & High & High \\
High & Low & Low & Low & High & Medium \\
Low & Low & Low & Low & Low & Low \\
Low & Low & Low & High & Low & Low \\
Low & Low & Low & High & Low & Low \\
Medium & Medium & Medium & Medium & High & Low \\
High & Low & Medium & Medium & Low & Low \\
High & High & High & Medium & Medium & Medium \\
High & Low & Low & Low & Low & Low \\
High & Medium & Medium & Low & Medium & Low \\
High & High & Medium & Medium & High & High \\
High & High & *Medium & Medium & High & High \\
Low & Low & Low & Low & Low & Low \\
High & High & High & High & High & High \\
High & Medium & Medium & Medium & High & High
\end{tabular}

\footnotetext{
* Depends on location distance from potential user.
} 
- Endorsement and leadership

- Tax incentives

- Higher education

- Endowed chairs

- Scholarships

- Competition

- Trade press

- Press conferences

- News releases

- Design awards

- Magazine feature articles

- Refered journal articles

- Texts, references, topical books

- Monographs

- Siide rules, quidelines

- Fact sheets

- Product literature

- Brochures

- Product directories and buyers' quides

- Radio and TV (viewed at air time)

- Talk shows

- Award presentations

- Public service announcements

- Paid announcements

- Documentaries

- Feature shows ("This 01d House," e.g.)

- Electronic media and fims (viewer control)

- Video tapes and discs

- Computer software

- On line databases

- Databases on PC media

- Teleconferences

- Electronic mail and bulletin boards 
- Trade shows and exhibits

- Cosponsors

- Booths

- Technical articles

- Demonstrations and model homes

- Loca 1

- Reqional

- National laboratory

- Government agency contacts

- National laboratories

- Federal bureaus

- Extension agents

- Industry colleagues

- Fellow professionals

- Construction project associates

- Industrial representatives

- Sales clerks

- Local sales reoresentatives

- Factory representatives

An analysis of media effectiveness for target audiences was carried out by Vonier \& Associates (see Table 4.3). This study also rated the various media mechanisms for costliness and difficulty.

Many publications available to members of the buildings industry orovide information on new energy-saving technologies. Frequentlv, these publications are written for segments of the buildings industry, and several of these publications are affiliated with institutes or associations. Appendix $C$ contains lists of building industry publications by reqion and affiliation. 

【

]

I

【

,

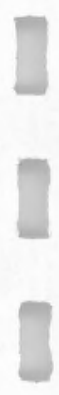

,

,

. 


\section{REFERENCES}

Achenbach, P. R., and W. W. Seaton. 1985. Proceedings of Buildings Industry Roundtable on Technology Transfer and Research Utilization. PNL-SA-12995, Pacific Northwest Laboratorv, Richland, Washington.

Booz, Allen and Hamilton. 1985. Market Analysis and Program for Use for Enerqy Conservation Manua?s: A Marketing Plan. Booz, Allen and Hamilton, Washinqton, 0.C.

Hotel and Motel Manaqement. Auqust 1984. "Franchising: Expansion Continues Viqorousiv at All Lodqinq Market Levels." Hotel and Motel Manaqement.

Murray, L. A. 1981. "The Product Growth Cvcle for Electro-0otic Technologies." Electro-Optical Svstems Design. oo. 55-61.

Rogers, E. M. 1962. Diffusion of Innovations. The Free Press, New York, New York.

Shama, A. June 1983. "Enerqy Conservation in U.S. Buildings." In Energy Policy. Butterworth and Company Ltd., London, Enqland.

U.S. Dexartment of Commerce. 1985. 1985 U.S. Industria] Dut look. U.S. Deoartment of Commerce, Washington, D.C. 

APPENDIX A

DATA ON SEGMENTS IN CONSTRUCTION CONTRACTING DIVISION 
DATA ON SEGMENTS IN CONSTRUCTION CONTRACTING DIVISION

CONSTRUCTION CONTRACTING

Construction Industries and Subdividers and Developers

Construction Industrv Sumary

This entrv summarizes all other entries for construction and develooment derived from the 1982 census of construction. Also included in this summary, but not reported elsewhere in this report are water well drilling contractors, wrecking and demolition work contractors, special trade contractors n.e.c., highway and street construction contractors, bridge, tunnel, and elevated highway construction contractors, water, sewer, pipe line, communication and power line construction contractors, and heavy construction contractors.

1982

Total Number of Establishments

447,887

Total Number of Establishments with

20 or Less Emplovees

Percentage of Industry Receipts Accounted

for by 4 Larqest Firms

Total Employment

$4,3 \hbar 1,852$

Value of Industry Receipts

$\$ 312.8 M M$

Value Added

$\$ 148.1 \mathrm{MM}$

Major Producing States:

Source: 1982 Census of Construction Industries (prelim.) 
Genera 1 Contractors - Sinqle Family Houses

SIC T5?T

Estabiishments in this industry segment are engaqed in the construction of single family houses, rowhouses, and townhouses (including new work, additions, alterations, remodelina, and repair).

\section{$\underline{1982}$}

Total Number of Establishments

72,061

Total Number of Establishments with 20 or Less Emplovees

Percentage of Industry Receipts Accounted for by 4 Larqest Firms

Total Employment 368,675

Value of Industry Receipts $\$ 22.2 M M \star \star$

Value Added $\$ 8.7 M M$

* \$6.3MM of this is subcontracted out

Maior Producina States: CA, TX, FL, PA, OH, IL

Source: 1982 Census of Construction Industries (prelim.) 
Genera? Contractors, Multi-Familv Residential

SIC 1522

Establishments in this industry are engaged primarily in the construction of apartment buildings, hotels, motels, and dormitories (including new work, additions, alterations, remodeling, and repair).

$\underline{1982}$

Total Number of Establishments $\quad 7,570$

Total Number of Establishments with

20 or Less Emolovees

Percentage of Industry Receipts Accounted

for by 4 Largest Firms

Total Emoloyment

65,5185

Value of Industry Receipts

$\$ 8.1 M M \star \star$

Value Added

$\$ 2.0 M M$

$\star \star \$ 4.4 M M$ of this is subcontracted out

Major Producing States: CA, TX, NY, IL

Source: 1982 Census of Construction Industries (prelim.) 
General Contractors - Nonresidential Buildings Other Than Industrial Buitiings and Warehouses

SIC 154?

Establishments in this industry segment are enqaqed in the construction of commercial, institutions, reliqious, and amusement and recreational buildings (including new work, additions, alterations, remodeling, and repair).

1982

Total Number of Establishments $\quad 29,184$

Total Number of Establishments with 20 or Less Emolovees

Percentage of Industry Receipts Accounted for by 4 Larqest Firms

Total Emoloyment $36.3,261$

Value of Industry Receipts $\$ 50.1 M M \star \star$

Value Added $\$ 13.4 M M$

$\star \$ 27.9 \mathrm{MM}$ of this is subcontracted out Major Producing States: CA, TX, NY, IL, FL

Source: 1982 Census of Construction Industries (prelim.) 
General Contractors - Industrial Buildings and Warehouses STC 1541

Establishments in this industry segment are enqaged in the construction of industrial buildings such as aluminum plants, automobile assembly plants, oharmaceutical manufacturing plants, and commercial warehouses (including new work, additions, alterations, remodeling, and reoair).

1982

Total Number of Establishments

7,406

Total Number of Establishments with

20 or Less Employees

Percentage of Industry Receipts Accounted

for by 4 Larqest Firms

Total Emoloyment

106,822

Value of Industry Receipts

$\$ 18.5 M M * \star$

Value Added

$\$ 5.9 M M$

* $\$ 8.9 M M$ of this is subcontracted out

Maior Producinq States: CA, MI, TX, AL

Source: 1982 Census of Construction Industries (orelim.)

A. 5 
Excavating and Foundation Work Contractors

SIC 1794

Establishments in this industrv are enqaged in excavation work, foundation work, and digaing and loading, in connection with building, heavy, or engineerina construction.

1982

Total Number of Establishments

17,368

Total Number of Establishments with

20 or Less Emplovees

Percentaqe of Industry Receipts Accounted

for by 4 Larqest Firms

Tota 1 Emoloyment

130,440

Value of Industry Receipts

$\$ 7.7 \mathrm{MM}$

Value Added

$\$ 5.2 M M$

Major Producing States: TX, CA, PA, IL, FL, NY, OH

Source: 1982 Census of Construction Industries (prelim.) 
Structural Steel Erection Contractors

SIC 1791

Establishments in this industry are engaged in the erection of structural stee 1, the placing of concrete reinforcement and structural iron work, and the erection of metal storaqe tanks.

\section{$\underline{1982}$}

Total Number of Establishments 3,592

Total Number of Establishments with 20 or Less Embloyees

Percentage of Industry Receipts Accounted for by 4 Largest Firms

Total Emoloyment 63,086

Value of Industry Receipts $\$ 3.6 \mathrm{MM}$

Value Added $\$ 2.4 M M$

Major Producing States: CA, TX, PA, IL, NY, FL

Source: 198? Census of Construction Industries (prelim.) 
Concrete Work Contractors

SIC 1771

Establishments in this industrv are engaged in concrete work and the surfacing of concrete floors, applying seal to concrete or asphalt surfaces, constructing with qunite and stucco, and constructing private driveways and walks of all materials.

1982

Total Number of Establishments

19,884

Tota 1 Number of Establishments with 20 or Less Embloyees

Percentage of Industry Receipts Accounted for by 4 Largest Firms

Tota? Employment

Va?ue of Industry Receipts

$\$ 9.7 M M$

Va lue Adder

$\$ 5.1 \mathrm{MM}$

Major Producing States: CA, TX, NY, IL, FL, OH

Source: 1982 Census of Construction Industries (prelim.) 


\section{Electrical Contractors}

SIC

Establishments in this industry are engaged orimarily in electrical work at the construction site. Also included are electric heating contractors and establishments engaged in the installation of intercommunication equioment, sound equipment, burglar alarms, fire alarms, and telephones.

$\underline{1982}$

Total Number of Establishments

38,470

Tota? Number of Estab 1 ishments with 20 or Less Employees

Percentage of Industry Receipts Accounted for by 4 Largest Firms

Total Employment 444,315

Value of Industry Receipts

Value Added

Major Producing States: CA, TX, NY, IL, FL, PA

Source: 1982 Census of Construction Industries (prelim.) 
Plumbing, Heating (Except Electric), and Air Conditioning Contractors SIC ITI!

Estab1ishments in this industry segment are enqaged in plumbing, heating (except electric), or air conditioning work or any combination of these types of work. Sheet metal work combined with any of these twes of work is included in this segment, but roofing and sheet metal contractors are classified in industrv 1761 .

1982

Total Number of Establishments

59,830

Total Number of Establishments with 20 or Less Employees

Percentage of Industry Receipts Accounted for by 4 Largest Firms

Total Employment 510,871

Value of Industry Receipts $\$ 32.6 \mathrm{MM}$

Value Adred $\$ 16.9 M M$

Major Producing States: CA, TX, NY, IL, FL, PA, OH, NJ

Source: 1982 Census of Construction Industries (prelim.) 
Plastering, Drvwa11, Accoustical and Insulation Contractors

SIC 174 ?

Establishments in this category are enaged in applying plaster, plain or ornamental; the installation of lathing or other appurtenances to receive plaster; or in drvwa11, accoustical, and building insulation work.

$\underline{1982}$

Tota? Number of Establishments

15,358

Total Number of Establishments with 20 or Less Emolovees

Percentage of Industry Receipts Accounted

for by 4 Larqest Firms

Tota 1 Emoloyment

209,244

Value of Industry Receipts

$\$ 9.9 M M$

Value Added

$\$ 6.0 M M$

Major Producing States: CA, TX, NY, IL, FL, PA,

Source: 1982 Census of Construction Industries (prelim.) 
Carpentering Contractors

SIC 1751

Establishments in this industry are primarily engaged in carpentry work and the installation of prefabricated windows and doors (except revolving doors). Shio joinery contractors are also inciuded in this industry.

\section{2}

Total Number of Establishments

30,634

Total Number of Establishments with

20 or Less Employees

Percentage of Industry Receipts Accounted

for by 4 Largest Firms

Tota1 Employment

134,000

Value of Industry Receipts

$\$ 5.5 \mathrm{MM}$

Value Added

$\$ 3.0 \mathrm{MM}$

Major Producing States: CA, TX, NY, IL, FL, PA, NJ

Source: 1982 Census of Construction Industries (orelim.) 
Floor Laying and Other Floorwork Contractors

SIC $175 ?$

Establishments in this industry segment are enqaged in 1aying, scraping, finishing, or refining of parquet and other hardwood flooring. Included are contractors that install asphalt tile, linoleum, and mastic and resilient flooring.

$\underline{1982}$

Total Number of Establishments

6,763

Tota 7 Number of Establishments with

20 or Less Employees

Percentaqe of Industry Receipts Accounted

for by 4 Larqest Firms

Total Employment

32,697

Value of Industry Receipts

$\$ 1.8 \mathrm{MM}$

Value Adder

$\$ 0.9 M M$

Ma.jor Producing States: CA, NY, TX

Source: 1982 Census of Construction Industries (prelim.) 
Terrazzo, Tile, Marble, and Mosaic Work Contractors

SIC 1743

Establishments in this industry segment are engaged in setting and installing ceramic tile, marble, and mosaic, and in mixing marble particles and cement to make terrazzo at the site of construction. Included are contractors engaged in fresco work and metel work.

\section{2}

Total Number of Establishments 3,860

Total Number of Establishments with 20 or Less Employees

Percentage of Industry Receipts Accounted for by 4 Larqest Firms

Total Employment 25,219

Value of Industry Receipts $\$ 1.2 M M$

Value Added $\$ 0.7 M M$

Ma.ior Producing States: CA, TX, FL Source: 1982 Census of Construction Industries (prelim.) 


\section{Masonry, Stone Setting and Other Stonework Contractors}

SIC 1741

Establishments in this industry segment are engaged in masonry work, stone settina, and other stonework. Included are boiler setting contractors, brick layina contractors, exterior marble contractors, and tuck pointing contractors.

$\underline{1982}$

Total Number of Establishments

20,057

Total Number of Establishments with 20 or Less Emoloyees

Percentage of Industry Receipts Accounted for by 4 Larqest Firms

Total Emplovment 120,273

Value of Industry Receints $\$ 4.3 \mathrm{MM}$

Value Added $\$ 2.7 M$

Major Producing States: NY, TX, CA, PA, IL, FL

Source: 1982 Census of Construction Industries (orelim.) 
Glass and Glazing Work Contractors

SIC 1793

Establishments in this industry are primarily engaged in glass and glazing work in connection with, but not limited to, building construction.

1982

Total Number of Establishments

3,864

Total Number of Establishments with

20 or Less Employees

Percentage of Industry Receipts Accounted for bv 4 Larqest Firms

Total Emoloyment

36,517

Value of Industry Receipts

$\$ 2.5 M M$

Value Added

$\$ 1.3 M M$

Major Producing States: CA, TX, NY, PA, FL

Source: 1982 Census of Construction Industries (orelim.) 
Painting, Paper Hanqing, and Decorating Contractors STC 1721

Establishments in this industry segment are engaged in interior and exterior painting (except roofs), paper hanging, and decorating.

$\underline{1982}$

Total Number of Establishments

24,880

Total Number of Establishments with 20 or Less Employees

Percentage of Industry Receipts Accounted for by 4 Larqest Firms

Tota 1 Employment

137,142

Value of Industry Receipts

$\$ 4.7 \mathrm{MM}$

Value Added

$\$ 3.4 M M$

Major Producing States: CA, TX, NY, PA, FL, IL

Source: 1982 Census of Construction Industries (prelim.) 
Installation or Erection of Building Equipment Contractors

SIC 1796

Establishments in this industry are primarily engaged in the installation of building equipment, not elsewhere classifier, such as elevators, escalators, pneumatic tube systems, and dust collection equipment.

$\underline{1982}$

Total Number of Establishments

3,753

Total Number of Establishments with

20 or Less Employees

Percentage of Industry Receipts Accounted

for by 4 Largest Firms

Total Emolovment

52,641

Value of Industry Receipts

$\$ 4.4 M M$

Value Added

$\$ 3.1 \mathrm{MM}$

Major Producing States: CA, TX, NY, PA

Source: 1982 Census of Construction Industries (orelim.) 
SIC 1761

Establishments in this industry segment are engaged in the installation of siding and roofing (including roof spraying, painting, or coating). Also included are contractors engaged in sheet metal work, except that rone in connection with plumbing, heating, or air conditioning.

\section{$\underline{1982}$}

Tota 1 Number of Establishments

21,215

Total Number of Establishments with 20 or Less Employees

Percentage of Industry Receipts Accounted for by 4 Largest $F$ irms

Total Employment 191,526

Value of Industry Receipts

$\$ 9.8 M M$

Value Added $\$ 5.5 M M$

Major Producinq States: CA, TX, FL, IL, NY, PA, OH

Source: 1982 Census of Construction Industries (orelim.) 

APPENDIX B

DATA ON SEGMENTS IN THE BUILDING MATERIALS AND COMPONENTS MANUFACTURING AND SUPPLY DIVISION 


\section{APPENDIX B}

DATA ON SEGMENTS IN THE BUILDINGS MATERIALS

AND COMPONENTS MANUFACTURING AND SUPPLY DIVISION

Hydrau lic Cement

SIC 241

Portland cement accounts for more than $90 \%$ of the output of the hydraulic cement industry. Other products include masonry, natural, preoared hydraulic, and lime cements. Usually about $30 \%$ of cement output is used for residential construction and $70 \%$ is used for nonresidential. Further breakouts according to end use are qiven in subsequent cement industry segments, which are subdivisions of hydraulic cement.

1983

1982

Total Number of Establishments

201

201

Tota 1 Number of Establishments with

41

20 or Less Employees

Percentaqe of Industry Receipts Accounted

for by 4 Larqest Firms

Total Emoloyment

23,000

27,000

Value of Industry Receipts

$\$ 3,809 M M$

$\$ 3,960 \mathrm{MM}$

Value Added

$\$ 2,020 \mathrm{MM}$

$\$ ?, 100 M M$

Major Producing States: TX, CA, PA, MI, MO

Source: U.S. Industrial Outlook, 1983, 1984 
Concrete Block and Brick

SIC 3271

About $50 \%$ of the outout of the concrete block and brick industry is used in residential construction. About $35 \%$ of the output goes to nonresidential building, and about $15 \%$ goes for other types of construction.

$\underline{1983} \quad \underline{1982}$

Total Number of Establishments

$1,273^{\star}$

Tota? Number of Establishments with

$925^{\star}$

20 or Less Emolovees

Percentage of Industrv Receiots Accounted 4*

for by 4 Largest Firms

Total Emoloyment

Value of Industry Receipts

Value Adder:

* 1981 data

Maior Producing States: PA, CA, MI, OH, TX

Source: U.S. Industrial 0utlook, 198?, 1983, 1984
16,900

16,000

$\$ 1,576 M M$

$\$ 1,445 M M$

$\$ 663 M M *$ 


\section{Ready Mixed Concrete}

SIC 3273

The ready mixed concrete industry ourchases more than $65 \%$ of all cement shipped in most years. About $40 \%$ to $45 \%$ of the output of the ready mixed concrete industry is used in residential construction, about $25 \%$ in nonresidential buildings, $8 \%$ to $10 \%$ in highways and streets, and the remainder in other nonbuilding construction.

1983

1982

Total Number of Establishments

Total Number of Establishments with 20 or Less Employees

Percentage of Industry Receipts Accounted for by 4 Larqest Firms

Tota? Employment

Vaiue of Industry Receipts

Va lue Added

* 1981 data

Maior Producing States: CA, TX, FL, OH, IL

Source: U.S. Industrial Outlook, 1982, 1984

$$
5,433^{\star}
$$$$
4,076 *
$$

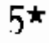

85,000

75,000

$\$ 9,073 \mathrm{MM}$

$\$ 8,735 M M$ 
Concrete Products N.E.C.

SIC 3272

The miscellaneous concrete products industry consists of producers of concrete pipe, precast concrete, prestressed concrete, and dry mix concrete. In most vears, the residential construction sector purchases only about $15 \%$ of the output of this industry, with another $20 \%$ purchased by nonresidential construction. The remainder goes to nonbuilding construction like highways and streets.

Total Number of Establishments

$3,916^{*}$

Tota 1 Number of Establishments with 20 or Less Employees

3,054 *

Percentage of Industry Receipts Accounted 9 * for by 4 Largest Firms

Tota 1 Emp Toyment

52,600 53,000

Value of Industry Receipts

$\$ 3,830 \mathrm{MM}$ $\$ 3,290 \mathrm{MM}$

Value Adder $\$ ?, 096 M M *$

* 1981 data

Maior Producing States: CA, TX, FL, OH, IL

Source: U.S. Industrial Out Took, 198?, 1984 
Brick and Structural $\mathrm{CT}$ ay TiTe

SIC 3251

Establishments in this industry seqment are engaaed in the production of bricks and structural clay tile. Bricks are used primarily in residential applications, while clay tile is used in non-residential.

$\underline{1983}$

1982

Total Number of Establishments

$352 \star$

Total Number of Establishments with

$90 *$

20 or Less Emb Joyees

Percentaqe of Industry Receiots Accounted 21* for by 4 Larqest Firms

Total Employment

13,900

15,000

Value of Industry Receipts

$\$ 987 M M$

$\$ 685 M M$

Value Added

$\$ 592 \star$

* 1977 data or based on 1977 data

Maior Producing States: NC, TX, OH, AL, SC

Source: U.S. Industrial Outlook, 198?, 1983, 1984 
Vitreous Plumbing Fixtures

SIC 3261

Between $60 \%$ and $70 \%$ of the industrv's output qoes to new residential buildings, about $15 \%$ to $20 \%$ qoes to new nonresidential buildings, and the remainder is used for replacements and additions in existing buildings. This industry is experiencing heightened competition from plastics manufacturers.

Total Number of Establishments

Total Number of Establishments with 20 or Less Employees

Percentage of Industry Receiots Accounted for by 4 Larqest Firms

Total Emoloyment

Value of Industry Receipts

Value Added

$\star 1981$ data

Maior Producina States: $O H, T X, P A$, IN

Source: U.S. Industrial Outlook, 1982, 1984 $\underline{1983}$

1982

$70^{*}$

$32 *$

62*

$8,000 \quad 8,000$

$\$ 613 M M$

$\$ 520 M M$ 
Meta 1 Plumbing Fixtures

SIC 3431

Between $60 \%$ and $70 \%$ of the industrv's output qoes to new residential buildings, about $15 \%$ to $20 \%$ qoes to new nonresidential buildings, and the remainder is used for replacements and additions in existing buildings. This industry is experiencina heightened competition from the plastics industrv.

1983

$\underline{1982}$

Tota? Number of Establishments

$101^{\star}$

Total Number of Establishments with

64 * 20 or Less Employees

Percentage of Industry Receiots Accounted for by 4 Larqest Firms

54 *

Tota 1 Employment

6,400

7,000

Value of Industrv Receipts

$\$ 638 \mathrm{MM}$

$\$ 495 M M$

Value Anded

$\$ 245 M M *$

* 1981 data

Maior Producing States: IL, OH, CA, TX, IN

Source: U.S. Industrial Out Took, 1982, 1983, 1984

B. 7 
Plumbing Fixture Fittings and Brass Goods

SIC $343 ?$

About $40 \%$ to $45 \%$ of the industrv output goes to new residentia 7 construction, and the same amount goes for replacement parts. The remainder goes into new nonresitential construction work.

$\underline{1983}$

1982

Total Number of Establishments

$213^{\star}$

Total Number of Establishments with

$103^{\star}$

20 or Less Employees

Percentage of Industry Receiots Accounted for by 4 Larqest Firms

Total Empioyment

15,200

20,000

Value of Industry Receiots

$\$ 1,655 \mathrm{MM}$

$\$ 1,415 M M$

Value Added

$\$ 7 ? 0 M M *$

* 1981 data

Major Producina States: CA, IN, OH, IL, TX

Source: J.S. Industrial Outlook, 1982, 1984 
Fabricated Structura 1 Meta 1

SIC 3441

Fabricated structural metal plants (SIC 344:L) convert metal into shapes (primarily steel) by cutting, bending, welding, drilling and other methods. The plants produce colums, joists and trusses. These are used primarily to build frameworks for buildings, bridges, and to a lesser extent, structures like oil drilling rigs. No breakout by end use was identified, so figures for this industry seament are slightly larger than they would be if we were able to consider only structural metals for commercial and residential buildings.

\begin{tabular}{cc}
$\frac{1983}{2,462^{\star}}$ & \multicolumn{1}{c}{$\frac{1982}{2,462^{\star}}$} \\
$1,388^{\star}$ & $1,388^{\star}$ \\
$10 \%$ & $10 \%$ \\
92,000 & 104,700 \\
$\$ 10,300 \mathrm{MM}$ & $\$ 7,300 \mathrm{MM}$ \\
$\$ 4,750 \mathrm{MM}$ & $\$ 3,360 \mathrm{MM}$
\end{tabular}

Total Number of Establishments

Total Number of Establishments with 20 or Less Employees

Percentage of Industry Receiots Accounted for by 4 Larqest F irms

Total Emoloyment

Value of Industry Receipts

Value Added 


\section{Prefabricated Meta 1 Buildings}

SIC 3448

Establishments in this industry segment manufacture metal buildings that can be installed on a Darticular site. The primary market for these buildings is for non-residential applications less than 150,000 square feet, including warehouses, small offices and restaurants.

Total Number of Establishments

Total Number of Establishments with 20 or Less Emolovees

Percentage of Industry Receipts Accounted for by 4 Largest Firms

Tota 1 Employment

VaTue of Industry Receipts

Value Added

Maior Producing States:

* 1981 data

Source: U.S. Industrial Outlook, 1983, 1984

$\underline{1983} \quad \underline{198 ?}$

$8,800 \star$

21,000

23,100

$\$ 2,030 \mathrm{MM}$

$\$ 2,100 M M$

B. 10 
Sheet Metal Work

SIC 3444

Establishments in this industry segment are engaged in manufacturing sheet metal products for the construction industry. Products include roof drainage equipment, soffits and fascia, siding, stove pipe, heating and air conditioning ductwork, awnings, carports, and drainage culverts. Another imoortant market for sheet metal products is air pollution abatement equioment, including air ductina, hoods, pans, convevor enclosures, ventilating ducts, and dust hopders.

\section{$\underline{1983} \quad \underline{1982}$}

Total Number of EstabTishments

Tota T Number of Establishments with 20 or Less Employees

Percentage of Industrv Receiots Accounted for by 4 Larqest Firms

Total Emplovment

72,100

79,700

Value of Industry Receipts

$\$ 5,750 \mathrm{MM}$

$\$ 6,700 \mathrm{MM}$

value Added

Major Producina States:

Source: U.S. Industrial Outlook, 1983, 1984 
Flat Glass

SIC 3?II

This industrv segment is enqaged in the manufacture of float, plate, tempered and laminated glass primarily for the construction and the automobile industries.

$\underline{2983}$

1982

Total Number of Establishments

Total Number of Establishments with

20 or Less Employees

Percentage of Industry Receiots Accounted

90

90

for by 4 Larqest Firms

Total Emoloyment

15,600

14,500

Value of Industry Receipts

$\$ 1,560 \mathrm{MM}$

$\$ 1,840 \mathrm{MM}$

Value Added

$\$ 850 M M$

$\$ 1,016 \mathrm{MM}$

Major Producing States: $O H, T N, I L, P A$

Source: U.S. Industrial Outlook, 1983, 1.984 
MATERIALS AND COMPONENTS MANUFACTURING AND SUPPLY

\section{Manufacturing Housing Firms}

Total Units Shipped, 1980

221,000

Percentage of Production Units Accounted for by 4 Largest Firms

Percentaqe of Production Units Accounted for by 30 Larqest Firms

Manufactured Homes as a Percentage of All Housing Units Sold in 1980

Source: Nutt-Powe 11, Thomas E. Manufactured Homes. Auburn House Publishing Company, Boston, Massachussetts, 198?. 
Current-carrying Wiring Devices

SIC 3643

1982

Value of shipments

$?, 558$

Total employment

45.3

Noncurrent-carrving Wiring Devices

SIC 3644

$198 ?$

Value of shioments

2,400

Total employment

26.3

Lighting Fixtures

SIC $3645,3645,3648$

1982

Value of shipments

4,040

Total employment

53.0

Sawmills and Planing MiTls, General SIC ?421

298?

Value of shipments

$11,897.1$

Total employment

153.1 
Hardwood Dimension and Flooring

SIC 2426

1983

Value of shioments

$1,143.3$

Total employment

23.0

Particleboard

SIC 2492

$\underline{1983}$

Value of industrial shioments 591

Value added 260

Total emoloyment $\quad 4.5$

Tota1 number of establishments 63

Percent of industry shioments accounted

for by 4 larqest coomoanies 48

Major producina states: OR, CA, MI, VA, GA, LA

Source: U.S. Industrial Outlook, 1984 
Softwood Veneer and Plrwood

SIC 7.4 .35

1983

Value of industry shipments

4,444

Value added

1,511

Total employment

39.1

Total number of establishments

256

Percent of inndustrv shipments accounted for by 4 largest companies

Major producing states: OR, TX, AK, LA, WA

Source: U.S. Industria? Outlook, 1984

Mi l lwork

SIC 2431

$\underline{1983}$

Value of shipments

$6,566.0$

Total employment

73.8

Structura 1 Wood Members, NEC

SIC 2439

1983

Value of shioments

$970 . ?$

Total employment

13.4 
APPENDIX C

SWEETS CATALDGUE RECIPIENTS 


\title{
APPENDIX C
}

\section{SWEETS CATALOGUE RECIPIENTS}

\author{
CONTRACT INTERIORS MARKET \\ INDUSTRY SEGMENT $\quad$ NUMBER OF FIRMS \\ $\begin{array}{ll}\text { Interior Design Dffices } & 2,966\end{array}$ \\ Interior Desian Departments in Architectural $\quad 1,470$ \\ Offices \\ $\begin{array}{ll}\text { Custom Contract Department } & 617\end{array}$ \\ $\begin{array}{ll}\text { Corporate Building Departments } & 644\end{array}$ \\ Federal, State, Municioal Department and 124 \\ Buying Aqencies \\ Schools, Libraries, Plan Rooms \\ 157 \\ TOTAL \\ 5,978 \\ HOMEBUILDING ANO REMODEL.ING MARKET \\ INOUSTRY SEGMENT \\ Builders and Contractors \\ Architectura1 offices \\ Builders and Contractors Employina Architects \\ Contractor Remodelers \\ NUMBER OF FIRMS \\ 8,578 \\ 1,831 \\ 178 \\ 8,174
}




\begin{tabular}{lr} 
Remotelers & 3,603 \\
Buildina Material Dealers & 2,879 \\
Dealer-Builders & 893 \\
Industrialized Buildina Manufacturers Miscellaneous & 274 \\
$\begin{array}{l}\text { Federal, State, Municioal Departments and } \\
\quad \text { Buying Aaencies }\end{array}$ & 18 \\
Libraries, Schools & -109 \\
\hline TOTAL & $25,5.38$
\end{tabular}

\section{MECHANICAL ENGINEERING MARKET}

\begin{tabular}{|c|c|}
\hline INDUSTRY SESMENT & NUMBER OF FIRMS \\
\hline Offices Doing Mechanical Engineering & 4,213 \\
\hline Engineers on Staff of Public \& Private Owners & 1,142 \\
\hline Desian Construct Enqineers & 307 \\
\hline Other Enaineering & 864 \\
\hline Contractors & 3,466 \\
\hline Schoo is & 155 \\
\hline TOTAL & 10,147 \\
\hline ELECTRICAL ENGINEERING MARKET & \\
\hline INDUSTRY SEGMENT & NUMBER OF FIRMS \\
\hline Offices Doing Electrical Enqineering & 3,746 \\
\hline Enqineers on Staff of Public and Private Owners & 1,231 \\
\hline Design Construct Enqineers & 306 \\
\hline Other Enqineering & 1,058 \\
\hline
\end{tabular}


Contractors

Schools

TOTAL

3,328

155

9,824

\section{CIVIL ENGINEERING MARKET}

INDUSTRY SEGMENT

Offices Doing Civil Engineering

Enqineers on Staff of Public and Private Owners

Design Construct Engineers

Other Engineering

Contractors

Schools

TOTAL
NUMBER OF FIRMS

6,028

1,501

310

585

1,254

155

9,833

GENERAL BUILDING AND RENOVATION MARKET

INDUSTRY SEGMENT

Architectural offices

Architectural and Engineering Offices

General Contracting Firms Employing Architects

Contracting Companies Emploving Architects and Enqineers

Soecialized Consulting Firms

Building Design Enqineers

Consulting Enqineers

Engineering and General Contracting Firms

General Contractina Firms

Construction Management Firms
NUMBER OF FIRMS

9,484

?, 335

739

108

79

331.

257

56

5,116

60

C. 3 
State, Municipal Departments and Buying Aqencies 384

Corporate Building Departments 899

Schools, Libraries, Plan Rooms $\quad 102$

$\begin{array}{ll}\text { TOTAL } & 19,850\end{array}$

INDUSTRIAL CONSTRUCTION AND RENOVATION MARKET

INDUSTRY SEGMENT

Architectura1 offices

Architectural and Enqineering Offices

General Contracting Companies Emploving Architects and Enqineers

Design Engineering Offices

Corporate Building Departments

Federa1, State, Municipal Departments and Buving Agencies

Schools, Libraries, Plan Rooms

TDTAL
NUMBER OF FIRMS

765

476

44

951

15,682

250

220

21,092 
APPENDIX D

PUBLICATIONS FOR BUILDINGS INDUSTRY 
PUAL ICATIONS IN BUII.DING REATED INDUSTRIES

Publication

ARCHITECTURE

Als Journal

AUA Neusletier

Architectural Record

CR IT

Fore \& Function

Historic Preservation

Progressive Architecture

BUILDING AND CONSTRUCTION

American Bullang Supplies

$\varnothing \quad$ Americon Roofer and Butlding

Improvement Contractor

Builder

Butlder \& Contractor

Butlding Design and Construction

Bullding Operating Management

Bullding Supply Neus

guildings

Comerercial Remodeling

Concrete Congtruction

Construction Bargat neer

Constuction Contracting

Construction Equipent

Cangtructor

Howe Center Magazine

Home Improvement Contractor

Targeted Audience

Circulation Frequency

City

State

Affiliatinn

Professional Architects

University Architecrs

Professional Architects

Architecture Students

Professional Architects

Trade Publication

Trade Publication

Home, Bvilder s

Contractors

Trade Publication

Comerctel awilders

Trade Publication

Construction \& Bldg. Mgat.

Recodelers

Trade Publication

Building Equipment Suppliers

Contructars

Equ1pent Suppl1ers/Buyers

Construction Menegera

Building Materials

Trade Publication
43.000 Wonthly Washingt on

controlled Quarkerly Lexington

77,000 Monthly New York

30,000 Semiannual Uashington

110,000 Quarterly Chicago

125,000 Bimonthy Washington

72,000 Monthly Stanf ord

\begin{tabular}{|c|c|c|}
\hline 34.500 & Monthly & At lante \\
\hline 30,000 & Monthly & Bollinas \\
\hline 35,000 & Monthly & Hashirgt on \\
\hline 18,500 & Monthly & Yash1ngt on \\
\hline 63.555 & Honthly & Des Plaines \\
\hline 65,000 & Monthly & Mil lusukee \\
\hline 36,568 & Monthly & Des Plaines \\
\hline 33,000 & Honthly & Cedar Rapids \\
\hline 40,100 & Bimonthly & Chicago \\
\hline 73.000 & Honthly & Addison \\
\hline 36,000 & Sedimonthly & St. Poul \\
\hline 58,503 & Nonthly & Redondo Beact \\
\hline 89,648 & $13 /$ Year & Des Playnea \\
\hline 20,000 & Monthiy & Washington \\
\hline 32,000 & Nonthly & Ch1cago \\
\hline & & Chis \\
\hline
\end{tabular}

IL

DC

CT

GA

ca

rc.

oC

11

UI

IL.

It

IL

IL

m

Ca

IL
American Institute of Architects

Association of Iniversity Architects

AIA, Assoctation of Student Chapters

U.S. Gypsum Co.

Nat lonal Trust for Histaric

Preservatian

Nat ional Association of Home Butlders Assoctated fulters and Contractors

Asgociated General Contractora of Anerica 
Honse Reaut iful's Building Manual

Insulation Dut look

\section{H Builder News}

Hanufactured Housing Newsletter

Hulti Housing Hews

Professional Ruilder and Apastment Business

Professional Remodeling

Remodeling Contractor

Shelter

Skylines

Sper ifying Engineer

Uepixly Abstract Newsletter:

Building Industry Technology

in

ENGINEFRING

ASHF, News

Civil Engtneering

Mechanical Engineers

Civil Engineers

rivil Fingincering for Practicing \& Civil Eagineers Design Engineers

Drsign Professional Product Ruitetin Directory

Fingineer ing Hews-Record

Engineer 3

Journal of Engineering Mechanics

Civil Engineers

Journal of Solar Energy Engineering

Journal of Structural Fngineerting

Structural Engineers

Journal of Struttural Mechanics

Hechanical Engineering

Structura! Engineers

Mechanical Engineers

Uorld Construction

\begin{tabular}{|c|c|c|}
\hline 175,000 & Quarterly & Hew York \\
\hline 18.000 & Monthly & Washington \\
\hline 11.693 & 6/Yeat & Chiraro \\
\hline 750 & Semimont hly & Rartingten \\
\hline 45.000 & Monthly & Nrw $Y_{1, k}$ \\
\hline 114,000 & Monthly & Des Plaines \\
\hline 36,627 & $11 /$ Year & Hew York \\
\hline 20.000 & Monthly & Hasbrouck Heights \\
\hline 25,000 & II/Year & Germantoun \\
\hline 5.000 & Monthly & Washingt on \\
\hline 37,000 & Mont hity & Des Plajnes \\
\hline 100.000 & Heekly & Springfirld \\
\hline
\end{tabular}

NY
NY

11

\section{National Remodelers Association}

Bullding Omers and Managers

Assoriation International

Nattonal Technical Inforation Service

\begin{tabular}{|c|c|c|c|c|}
\hline Unknown & Monthly & New York & NY & $\begin{array}{l}\text { American Society of Hechanical } \\
\text { Engineers }\end{array}$ \\
\hline 90,000 & Monthly & New York & NY & American Society of Civil Englneers \\
\hline$\cdots$ & Bimonthly & Elmsford & NY & \\
\hline Unknown & Quarterly & Bartingtan & IL & \\
\hline 106,000 & Wetkly & Hew York & NY & \\
\hline 4,300 & Binonthly & New York & NY & American Society of Civil Engineers \\
\hline Unknown & Quarter $1 y$ & New Yurk & NY & $\begin{array}{l}\text { American Society of Mechanical } \\
\text { Engineers }\end{array}$ \\
\hline 8,800 & ManthIy & New York & NY & American Society of Civil Engineers \\
\hline Unknoun & 4/Year & New York & NY & \\
\hline 80,000 & Monthly & New York & NY & $\begin{array}{l}\text { American Society of Mechanical } \\
\text { Engineers }\end{array}$ \\
\hline 30,500 & Mont hly & New York & NY & Dun \& Bradstreet \\
\hline
\end{tabular}


ORGANIZATIOKS IN BUILAINL; RELATED INIMISTKIES

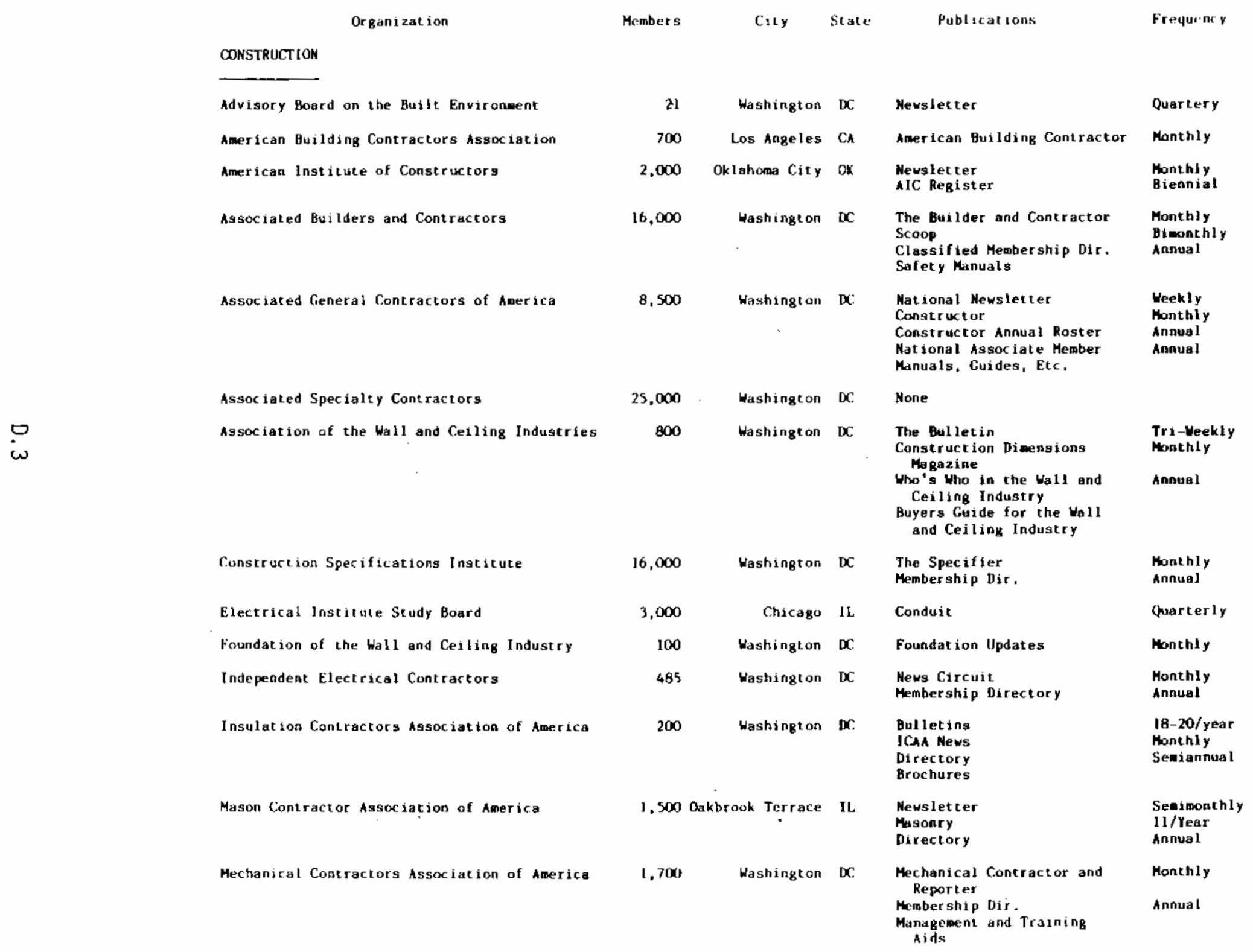




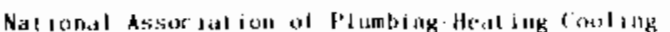
(1., 3) National Assorialion of Wemen in Comsitructron National Electrical Contractors Asseriat lem

Natsunal Institute of Building Srjetuces

National Insulation Contractors Association

Nal ronal koufing Constructors Associal ion

\section{BUIJ.DING INDISTRIFS}

\section{Building Owhers and Managers Assuc jation} Internatronal

Homm. Manufacturess Council of MAllB
Chrago It

Wastingtion in

Wuslungtun

Claciatis 11

ispe-kal kS
Newstelter Electrical contrictor

Hixelzilli,

Eleciro fact Filo

Total Energy Mgml. Series

NFCA SI andarits

Building Sicience Newsiclter

Techorical Pubitications

\section{Insulet jon but book}

Insulat ox

iabur Re'por

Disertury

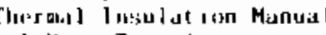

8 Heal Trinster

\section{The Rurf ing Spec.}

Actuon Information

Directury

Mesol trly

Werkly

Montlity

Monthty

Hont lity

Monstily Murithly Bimonthily

Annual

h/Year

S/Year

Annual

\section{Skylines \\ Suciety of Real Property}

Admini ist rat ars

Clapiancy Survey of office buslditigs

Annual Membership and

Commitee Darector

Corvention Dirtectory
Income and Cose atalysis

Manchly

Quat zer ty

Scmiannual

Annuit

Asnuil

\section{Monthly}

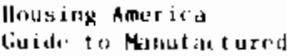

$$
\begin{aligned}
& \text { (autde to } \\
& \text { Hommesi }
\end{aligned}
$$

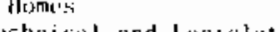

$$
\text { Bulletins }
$$

Nrus \& Virus
Hember ship Surveys Mermbir ship Rositer

$$
\text { and Misnugrams }
$$

Monthly Semiannuist 
American Institute of Architecture

Anerican Institute of Building Designers

Association of Collegiate Schools of Architecture

Association of Student Chapters, A]

Association of Eniverstcy Architects

National Institute for Architectural Education

Society of Anerican Registered Architects

ENGINEER J NG

American Consulting Engineers Council

merican Society of Heating, Refrigeration,

and Air-Conditioning Engineers

MAMTACTURED HOUSJMG

Coordinating Council on Manufactured Housing Finance

Manufactured Housing Institute
Washington $D C$

30.000

, 600

Hashingt on $b$

At lanti Ga

45,000

\section{Trangaction}

Handbook

kubership Roster

Semimonthly

Monthly

Mernt til

A

Quariarly

Arnuaj

Bimonthly
Quarterly

Annual

Biennal

Semimontily

$7 /$ Year

Quarterly

Annual

Quarterly

Weik kly Annual

Mont hily

Annual

Biennial

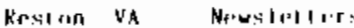




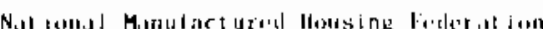

Nal ional Manufartured llousing

Futance Assor iastion

AITOMATIC: CONTROS

American Autematic Cont rol Counc $\mathrm{j}$

Internationa? Federation of Aut omat ic Control

Numerical control Society

ITISER

Alr-Condilloning and Refrigeral in Insiltule

Hydronics Institute

Illuminal ing Fngineterang Sockety of Nurlth Amez ic it

Internartional Associaltion of L, ght ing Desigturs

Nat ional Assorialion of titectrical Distributors Nat ional Fileciricia! Manufarturers Assuctation

None

42

$4,0(x)$

160

Artington va

Roldtax

longislative Soreciard

Stalle Gove'turtent Aftiors

Dat it Besik

Applied fiqupmen Direutory

tinitaty liquipment Directory

Transport Directory

Water Coolers Directory

75 Rerkeley Herghts: N.I

Builders Choice

Puilders laig
HWAC. Dal a file

liydronics Markel ing

St teonl Heat ing Fiat t:

Itak Sichuel Niusictler

10,000

No York NY

1.1 ghtt ing Detsign int

Application

l.ight ing Handbook

New York NY Neswslettior

Fiectrical Distributor

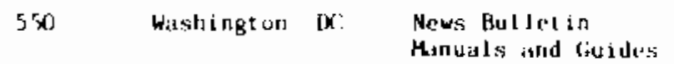

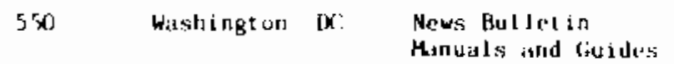

20) Solver Spring Mro Technical Bulletins
Bimonthly

Bimont hly Bimonthly

Monthly Munifily Moritity y

Semiantutal Semi antral Annual Annua1

3/Year

3/Year

$3 /$ rials

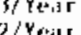

2/roir

Monahy Quarterly
Qu inquinnia

Mouthly

Monthly

Manthly 
RPIONAL PUALICATIONS IN BHLDING, RELATED INDASTRIFS

Publication

BUILDING AND CONSTRUCTION

\begin{tabular}{|c|c|}
\hline $\begin{array}{l}\text { Builder Architect-Contractor } \\
\text { Engineer }\end{array}$ & Builders \\
\hline Builder Developer Hest & Apartment Contrackors \\
\hline Building Construction News & Builders \\
\hline California Builder & Sull ders \\
\hline California Builder and Engineer & Builders \\
\hline Connecticut Construction & Builders \\
\hline Contracting in the Carolinas & Contractors \\
\hline Dixie Contractor & Contractors \\
\hline Illinois Butlding News & Bullding Suppliers/Buyers \\
\hline Intermountain Contractor & Contractars \\
\hline Loutsiane Contractor & Contractors \\
\hline Michigan Contractor Builder & Engineers and Builders \\
\hline Mid-West Contractor & Contractors \\
\hline New England Construction & Builders \\
\hline $\begin{array}{l}\text { New Jersey Shore Builders } \\
\text { Association Bulletin Board }\end{array}$ & Bu1lders \\
\hline $\begin{array}{l}\text { Northwest Construction Neus } \\
\text { Daily/Neekly }\end{array}$ & Butlders \\
\hline Pacific Bullder and Engineer & Engineers and Builders \\
\hline Rocky Hountaln Construction & But1derg \\
\hline $\begin{array}{l}\text { Southern California Heavy } \\
\text { Construction }\end{array}$ & Engineers \\
\hline Southern Bullding & Bullding Codes \\
\hline Sun Coast Architect Builder & Architects/Butlders \\
\hline Texas Contractor & Contractora \\
\hline Utah Construction Report & But1ders \\
\hline
\end{tabular}

Circulation Frequency Ciry

Siate Rerion

\begin{tabular}{|c|c|c|c|c|}
\hline 3,300 & Monthly & Phoenix & $\boldsymbol{M} Z$ & Southwest \\
\hline 25.618 & Honthly & Anaheim & $\mathrm{GA}$ & West Const/Californla \\
\hline controlled & MonthIy & Cleveland & OH & Northern Ohio \\
\hline 0.000 & Honthly & San Francisco & $\mathrm{CA}_{\mathrm{A}}$ & California \\
\hline 12,000 & Bimonthly & Pala Alto & $\mathrm{CA}$ & California \\
\hline 3,400 & Bimanthly & Farmingt on & CT & Connecticut \\
\hline 4.590 & Quarterly & Darlingtan & sc & North and South Carolina \\
\hline 8,757 & Fortenight ly & Decatur & GA & Southeast \\
\hline 1,500 & Monthly & Springfield & IL & Il11nois \\
\hline 3,000 & Weekly & Sult Lake City & vT & Rocky Hountaing \\
\hline 6,000 & Monthly & Baton Rouge & w & Loutstans \\
\hline 3,693 & Weekly & Detroit & MI & Michigan \\
\hline 8,333 & 2/Month & Kansas City & MO & Midwest \\
\hline 5,168 & Fortnight ly & Lexington & MA & Nex England \\
\hline 2,200 & Monthly & Brick Town & NJ & Mew Jersey Shore \\
\hline unknown & Dally/Weekiy & Seattle & $H_{A}$ & Northwegt \\
\hline 8,900 & Seminonth1y & Seattie & wh & Pactfic Coast/Worthwest \\
\hline 9.712 & Fortnightly & & $\infty$ & Rocky Mountaing \\
\hline 5,700 & $9 /$ Year & Senta Fe Springs & $a$ & Southern Callfornia \\
\hline 5,100 & Binonthly & B1rmingham & AL. & Southeast \\
\hline 40,300 & Monthly & Los Angeles & $a$ & Pacific Coast \\
\hline 5,719 & Seminonthly & Dallas & $\pi$ & Texas \\
\hline 1,750 & Quarterly & Salt lake City & UT & Utah \\
\hline
\end{tabular}


West Virginia Construction Neus

Hestern Builder

ENGINEERING

CIM Construction Journal

Ohio Count y Engineers' News

\section{Contractors}

Engineers and Builders

\section{Engineers}

Engineers

\begin{abstract}
1.200 Bimonthly
4.600 Week $1 y$
\end{abstract}

850 Weekly

5,200 Quarterly
Boston

Cal umbus

\section{Hest Virginta}

Wisconsin, upper Mlehiann, N. Ill tania

Canstruction Industries of Fagsachuset

County Engineers Assoctation of Otho 


\section{DISTRIBUTION}

No. of

Copies

OFFSITE

J. MiTlhone

U.S. Department of Energy

1000 Independence Ave., S.W.

Forrestal Building, GF-231

Washington, D.C. 20585

F. Abel

U.S. Department of Energy

1000 Independence Ave., S.W.

Forrestal Building, GF-231

Washington, D.C. 20585

D. Jones

U.S. Department of Energy

1000 Independence Ave., S.W.

Forresta] Building, GF-231

Washington, D.C. 20585

30 DOE Technical Information Center

J. Smith

U.S. Department of Energy

1000 Independence Ave., S.W. Washington, D.C. 20585

20 M. Gorelick

U.S. Department of Energy

1000 Independence Ave., S.W. Forrestal Building, GF-253

Washington D.C. 20585

T. Kapus

U.S. Department of Energy

1000 Independence Ave., S.W.

Forresta] Building, GF-217

Washington, 0.C. 20585

L. Connor

U.S. Department of Energy

1000 Independence Ave., S.W.

Forrestal Building, GF-217

Washington, D.C. 20585
J. HoImes

U.S. Oepartment of Energy

1000 Independence Ave., S.W.

Forrestal Building, 5H-095

Washington, D.C. 20585

K. Haas Smith

7210 Trescott Ave.

Takoma Park, MD 20912

M. Brown

Energy Division

Oak Ridge National Laboratory

P.0. Box $X$

Oak Ridge, TN 37831

3 T. Vonier

3741 W Street, N.W.

Washington, D.C. 20007

E. Bales

Campbel1 Hall

School of Architecture

New Jersey Institute of Technology

Newark, NJ 07102

P. Ruch

Sumner Rider \& Associates, Inc.

355 Lexington Ave.

New York, NY 10017

B. Seaton

American Society of Heating,

Refrigeration and Air Conditioning

1791 Tullie Circle, N.E.

Atlanta, GA 30329

J. L. Eisenhauer

Battelle Washington Operations

2030 M Street, N.W.

Washington, 0.C. 20030

J. C. Franke

Battelle Washington Operations

2030 M Street, N.W.

Washington, O.C. 20030 
L. Crumas

Battelle Washington Operations

2030 M Street, N.W.

Washington, D.C. 20030

\section{ONSITE}

DOE Richland Office

H. E. Ransom
47 Pacific Northwest Laboratory

R. C. Adams

W. B. Ashton

M. Clement

R. M. Fleischman

D. R. Johnson (30)

B. L. Mohler

S. A. Sinith

R. L. Watts

E. J. Westergard

Economics Library (2)

Publishing Coordination (2)

Techrical Information (5) 